Discussion Paper No. 08-128

\title{
FDI and Taxation
}

A Meta-Study

Lars P. Feld and Jost H. Heckemeyer

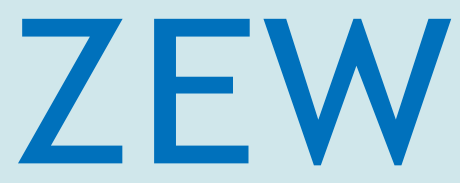

Zentrum für Europäische Wirtschaftsforschung $\mathrm{GmbH}$

Centre for European

Economic Research 


\title{
Discussion Paper No. 08-128
}

\section{FDI and Taxation \\ A Meta-Study}

\author{
Lars P. Feld and Jost H. Heckemeyer
}

Download this ZEW Discussion Paper from our ftp server:

\section{ftp://ftp.zew.de/pub/zew-docs/dp/dp08128.pdf}

Die Discussion Papers dienen einer möglichst schnellen Verbreitung von neueren Forschungsarbeiten des ZEW. Die Beiträge liegen in alleiniger Verantwortung der Autoren und stellen nicht notwendigerweise die Meinung des ZEW dar.

Discussion Papers are intended to make results of ZEW research promptly available to other economists in order to encourage discussion and suggestions for revisions. The authors are solely responsible for the contents which do not necessarily represent the opinion of the ZEW. 


\section{Non-technical summary}

Despite the continuing political interest in the usefulness of tax competition and tax coordination as well as the wealth of theoretical analyses, it still remains open whether or when tax competition is harmful. Moreover, the influence of tax differentials on multinationals' decisions is still insufficiently analyzed. Thus, economists have increasingly resorted to empirical analysis in order to gain insights on the elasticity of foreign direct investments (FDI) with respect to company taxation. As a result, the empirical literature on taxation and international capital flows has grown to a similar abundance during the last 25 years as the respective theoretical literature. Its heterogeneity leads to a rising need for concise reviews on the existing empirical evidence. In this paper we extend former meta-analyses on FDI and taxation in three ways. First, we add the most recent publications unconsidered in meta-analyses up-todate. Second, we apply a different methodology by using a broad set of meta-regression estimators and explicitly discuss which one is most suitable for application to our meta-data. Third, we address some important issues in research on FDI and taxation to the clarification of which meta-analysis can make valuable contributions. These issues are mainly: The influence of variables which might moderate effects of tax differentials (e.g. public spending), the implications of using aggregate FDI data as opposed to firm-level information on measured tax effects, the implications of bilateral effective tax rates, and the possible presence of publication bias in primary research.

According to our meta-analysis, a pooled effect based on the median result taken from each primary study could be obtained that amounts to a semi-elasticity for company taxes on FDI (percentaged reaction of FDI to one percentage point change in the tax burden) of 1.68 in absolute terms.

We do not find overwhelming support for publication bias in the meta-regressions. The use of aggregate data leads to higher estimated semi-elasticities, but significantly reduces t-values and thus implies less precise estimates. Regarding the choice of tax rates, unilateral effective average tax rates do not lead to significantly higher tax effect size estimates or significances as compared to the statutory rate. Bilateral tax rates best capture tax incentives and yield both significantly higher effect size estimates as well as higher significances. Regarding the control variables, it is most interesting that primary estimates are not significantly affected by the inclusion of public spending. This might be due to the fact that only crude measures of public inputs are used in many studies. 


\section{Zusammenfassung}

Trotz des hohen politischen Interesses an den Themen des Steuerwettbewerbes bzw. der Steuerharmonisierung und der daraus resultierenden Vielzahl theoretischer Analysen zum Thema bleibt die Frage nach deren ökonomischen Implikationen letztlich noch unbeantwortet. Insbesondere der Einfluss des internationalen Steuergefälles auf die Investitionsentscheidungen multinationaler Unternehmen ist deshalb zunehmend ein Objekt der empirischen Analyse geworden.

Die empirische Literatur zum Zusammenhang zwischen Besteuerung und ausländischen Direktinvestitionen (ADI) der vergangenen 25 Jahre ist indes von einer ähnlichen Diversität geprägt wie die entsprechenden theoretischen Analysen. Diese Heterogenität der Ergebnisse führt zu einem steigenden Bedarf an präzisen, methodisch fundierten und vor allem quantitativen Übersichtsstudien (sog. Meta-Analysen) über die bestehende empirische Evidenz. In dieser Arbeit werden vorhergehende Meta-Studien zum Thema Besteuerung und ausländische Direktinvestitionen auf dreifache Weise erweitert. Zunächst wird die Datengrundlage der quantitativen Meta-Analyse um die aktuellsten Studien bereichert. Ein ausführlicher methodischer Teil der Analyse wird anschließend unterschiedliche Schätzverfahren zur Durchführung von Meta-Regressionen in einem integrierten ökonometrischen Rahmen darstellen und zudem eine Strategie zur Auswahl des zur Analyse der vorliegenden Meta-Daten präferierten Verfahrens entwickeln. In einem dritten Schritt werden anschließend wesentliche Aspekte untersucht, deren Diskussion in der aktuellen empirischen Literatur von Bedeutung ist. Die Methodik der Meta-Analyse ist geeignet, für zahlreiche dieser Aspekte einen klärenden Beitrag zu generieren. $\mathrm{Zu}$ den im Detail untersuchten Fragestellungen gehört der potenziell mildernde Einfluss der Ausgabenseite des öffentlichen Budgets auf den (abschreckenden) Steuereffekt. Zudem werden die Implikationen der Verwendungen aggregierter Daten (im Gegensatz zu Informationen auf Firmenebene), die Implikationen der Verwendung bilateraler Steuerbelastungsmaße (im Gegensatz zur Verwendung unilateraler Steuerbelastungsmaße ohne Berücksichtigung bilateraler steuerlicher Regelungen) sowie die mögliche Existenz einer publikationsbedingten Verzerrung der in der Primärliteratur gemessenen Effektgrößen (sog. publication bias) untersucht.

Im Ergebnis ermittelt die vorliegende Arbeit u.a. eine präzisionsgewichtete durchschnittliche Semi-Elastizität (prozentuale Reaktion der ADI auf eine Variation der Steuerbelastung um einen Prozentpunkt) von absolut 1.68, basierend auf den Median-Resultaten aus jeder der berücksichtigten Studien. Keine eindeutige Evidenz findet sich für das Vorliegen von 
publication bias. Indes scheint die Verwendung aggregierter Daten die gemessenen adversen Effekte der Besteuerung auf ADI zu verstärken, die Präzision der Schätzung jedoch zugleich zu verringern. Bilaterale Steuerbelastungsmaße führen zu (absolut) höheren primär gemessenen Steuereffekten als ihr unilaterales Pendant. Sie scheinen somit eher geeignet, die von der Besteuerung ausgehenden Anreize auf transnationale Investitionsentscheidungen zu erfassen. Interessanterweise konnte kein mildernder Effekt von Größen auf der Ausgabenseite des öffentlichen Budgets auf die abschreckende Wirkung der Besteuerung nachgewiesen werden. Dies könnte als Hinweis auf die bisherige Verwendung unzureichender Maße für die Bereitstellung der aus Unternehmenssicht relevanten öffentlichen Güter gewertet werden. 


\title{
FDI and Taxation
}

\author{
A Meta-Study
}

\section{Lars P. Feld*, Jost H. Heckemeyer**}

December 2008

\begin{abstract}
:
Despite the continuing political interest in the usefulness of tax competition and tax coordination as well as the wealth of theoretical analyses, it still remains open whether or when tax competition is harmful. Moreover, the influence of tax differentials on multinationals' decisions is still insufficiently analyzed. Thus, economists have increasingly resorted to empirical analysis in order to gain insights on the elasticity of FDI with respect to company taxation. As a result, the empirical literature on taxation and international capital flows has grown to a similar abundance during the last 25 years as the respective theoretical literature. Its heterogeneity leads to a rising need for concise reviews on the existing empirical evidence. In this paper we extend former meta-analyses on FDI and taxation in three ways. First, we add the most recent publications unconsidered in meta-analyses up-to-date. Second, we apply a different methodology by using a broad set of meta-regression estimators and explicitly discuss which one is most suitable for application to our meta-data. Third, we address some important issues in research on FDI and taxation to the clarification of which meta-analysis can make valuable contributions. These issues are mainly: The influence of variables which might moderate effects of tax differentials (e.g. public spending), the implications of using aggregate FDI data as opposed to firm-level information on measured tax effects, the implications of bilateral effective tax rates, and the possible presence of publication bias in primary research.
\end{abstract}

JEL-Classification: H25, H73, F23, F21.

Keywords: Corporate Income Taxation, Foreign Direct Investment, Meta Analysis.

We are extremely grateful to Ruud de Mooij for generously providing his data set to us. We also would like to thank Laura Kaeding, Ivan Mitrovic, Benjamin Protte and Frank Schneider for very valuable research assistance.

The authors also would like to thank Martin Paldam, Doina Radulescu, Gonzague Vannoorenberghe and other participants at the IIPF Conference in Maastricht, the MAER Workshop on Meta-Analysis in Nancy and the joint Ph.D. workshop in Mannheim for helpful comments.

\footnotetext{
* Prof. Dr. Lars P. Feld holds the Chair of Public Economics at Heidelberg University and is research associate at the Centre for European Economic Research (ZEW).

(lars.feld@awi.uni-heidelberg.de)

** Jost H. Heckemeyer is researcher at the Centre for European Economic Research (ZEW).

(heckemeyer@zew.de)
} 


\section{Introduction}

The political interest in tax competition, coordination and harmonization has remained high in Europe for more than 45 years (see the Neumark-Report published in 1963). ${ }^{1}$ After successful coordination and harmonization in indirect taxation, company taxes attract attention in ensuing debates. Most recently, the EU considers a harmonization of corporate taxation in form of a common consolidated corporate tax base (CCCTB) combined with formula apportionment (Martens-Weiner 2006, Schön, Schreiber and Spengel 2008). Not surprisingly, the scientific interest in international tax competition has considerably increased since harmonization efforts in Europe intensified, but also due to rising capital mobility in the last thirty years. Theoretical studies in public economics provide the conditions for tax competition being harmful and tax coordination being useful. These conditions are however numerous and heterogeneous (see the surveys by Wilson 1999, Feld 2000, Wilson and Wildasin 2004, Fuest, Huber and Mintz 2005). Without referring to empirical evidence, no unambiguous predictions could be obtained. As a result, the empirical literature on tax competition has heavily grown in recent years sadly leaving us with a similarly diverse picture as the theoretical analyses (see the surveys by Hines 1997, 1999, Devereux 2006). In contrast to theoretical analyses, economists could however adopt meta-analytical methods from the life sciences to gain clearer insights as to the effects of international taxation instead of the usual narrative surveys on empirical results (Jarrell and Stanley 1989, 2005, Stanley 2001). De Mooij and Ederveen (2003, $2005,2006)$ pioneer this approach in the economics of international taxation.

As the role of multinational firms and problems of financial arbitrage are increasingly focused in the theoretical analyses on the impact of international tax differentials on foreign direct investment (FDI) (Fuest, Huber and Mintz 2005), the multinationals' options for location choice are the starting point for empirical analyses. Dunning (1981) identifies three advantages, called O-L-I, that have to be present for a multinational to invest in foreign host countries. Besides locational advantages (L) offered by the host country, to which taxation belongs, the multinational should be able to realize firm-specific advantages as compared to domestic enterprises in order to successfully compete with them despite of costs of setting up activities in a foreign country. The ownership advantages $(\mathrm{O})$ must therefore be complemented by an internalization advantage (I) over, e.g., licensing of foreign production.

1. Debates about the effects of tax competition certainly date back much earlier, at least if the situation within countries is additionally considered. Spoerer (2002), e.g., provides historical accounts of tax reform discussions in Zurich in 1883 pointing to the "flights of the capitalists" induced by the enormous tax differential to the canton of Basel (see also Georg von Schanz 1890). Another historical study extending the analysis of interjurisdictional competition into pre-modern Germany between 1000 and 1800 stems from Volckart (2002). 
This broad perspective on FDI allows for a consideration of other factors influencing multinationals' investment decisions. In particular, studies in international economics distinguish horizontal expansions from vertical investment decisions and analyze both issues separately. Multinationals that engage in horizontal investments want to establish production abroad in order to serve local markets. In contrast, vertical investments serve to geographically allocate a company's production chain with the aim of exploiting inter-locational differences in relative factor endowments. Based on these insights, Horstmann and Markusen (1992) develop an instructive theory on horizontal FDI. They show that a multinational will locate production in direct proximity to a foreign market if the corresponding reduction of distance-related costs is advantageous as compared to the reduced potential of exploiting economies of scale at the plant-level. The more important economies of scale are, the less likely local production will become (at least in small foreign countries). As to vertical FDI, Helpman $(1984,1985)$ explains the splitting of the value chain as being driven by the multinational's aim to reduce total production costs. As long as reductions in production costs, due to lower factor prices abroad, exceed corresponding set-up costs, the multinational firm will engage in foreign (unskilled-labor intensive) production. Eby-Konan, Markusen, Venables and Zhang (1996) and Markusen $(1997,2002)$ finally present a unified approach. Their so-called knowledge-capital model explains both, horizontal and vertical, motivations for foreign investment. This model has become the standard theoretical approach in FDI research.

This theoretical perspective on the multinationals' investment decisions in a world of international tax differences underlines the importance of additional factors influencing FDI and thus of the ceteris paribus assumption in tax competition analyses. Some recent empirical studies on FDI and taxation pursue the above-mentioned concepts in order to derive a theoretically well-founded estimation strategy. ${ }^{2}$ However, many studies instead opt for a traditional gravity set-up as successfully applied in the empirical trade analyses. The gravity approach explains inter-country FDI patterns by a combination of mass variables (e.g. GDP, population) and distance variables. This simple set-up is regularly augmented by presumably important policy and locational factors. These are - in addition to a measure of taxation - indicators for political risk, openness, infrastructure, labor costs, etc. Thus, they often employ sets of explanatory variables whose possible importance is also justified by theoretical considerations.

In addition to the underlying theoretical concepts, empirical studies on FDI and taxation vary widely with respect to specification, sample size and so on. One very important aspect in

2. Early empirical studies implicitly relied on q-style investment models (Hines 1999). 
which they differ is the dependent variable. Since FDI in its broad definition does not only comprise real investments but also financial flows due to mergers or acquisitions of already existing capital, some authors prefer to use a dependent variable which better reflects real economic activity. They therefore rely on investments in stocks of property, plant and equipment (PPE) which are undertaken or held by foreign affiliates in a particular host country.

The central explanatory variable, i.e. the tax variable, also varies on the basis of different alternative concepts. Besides the use of statutory tax rates at the country or regional level, many empirical studies rely on average tax rates. In contrast to statutory tax rates, average tax rates reflect the tax base to which statutory tax rates apply. They are computed on the basis of previous microeconomic or macroeconomic data and are therefore also known as backwardlooking tax measures. One special feature of backward-looking tax measures is that they capture the "true" tax burden on investments or companies. Since they are based on actual tax payments they reflect the outcome of tax planning and discretionary tax provisions. However, one of their major caveats also lies in this backward-orientation. As Devereux (2006) points out, average tax measures might introduce an endogeneity bias into empirical analyses. Since they are based on previous data, average tax rates might be influenced by recent investments (e.g. through depreciation allowances). The direction of causation between the dependent FDI variable and the average tax rate thus might be ambiguous.

From a theoretical point of view it is preferable to use tax measures which are forward-looking and thus better reflect the situation investors are in when they decide. Forward-looking tax measures are differentiated into effective marginal and effective average tax rates. Effective marginal tax rates measure the tax-induced relative wedge between pre- and post tax returns on marginal investment. They are mainly calculated using neoclassical investment models developed by King and Fullerton (1984) or Devereux and Griffith (1998, 1999). Devereux and Griffith (1999) also calculate effective average tax rates, which measure relative tax-induced reductions of the net present value of inframarginal, i.e. profitable, investments. ${ }^{3}$ These measures reflect the major provisions of the considered tax system in a transparent and compact way. They most importantly correspond to the forward-looking nature of investment decisions which are taken on the basis of future taxes triggered by the respective projects.

The meta-analyses by De Mooij and Ederveen (2003, 2005, 2006) particularly study to what extent the choice of tax rates and the differentiation in the type of investment influence the

3. Effective average tax rates might also be calculated by means of modeling a representative company's financial development over a certain period of time. See Spengel (1995) or Jacobs and Spengel (1996). 
results of empirical studies on tax competition. They put less emphasis on the control variables which are used in those studies. Most importantly, the impact of public spending on multinationals' investment decisions has received little attention there. Adopting the traditional Tieboutian (1956) perspective on inter-jurisdictional tax differences, the spending side must however not be neglected. This has been recognized by theoretical studies (Keen and Marchand 1997, Sinn 2003) and much emphasized by Bénassy-Quéré, Gobalraja and Trannoy (2007) in their recent empirical analysis. Similarly, Baldwin and Krugman (2004) show that agglomeration effects in geographic centers might allow governments to tax business more heavily. In a recent unpublished paper, Brülhart et al. (2007) present evidence for newly founded firms that agglomeration effects actually reduce their sensitivity to tax differentials.

In this paper, we provide a meta-analysis on the impact of company taxation on FDI by particularly asking to what extent this impact is moderated by spending policies or agglomeration effects. In addition to the use of a broader data set by inclusion of most recent studies, a methodological expansion is made by employing a broad set of meta-regression estimators. We explicitly test which estimator is most suitable with respect to the underlying data. Metaregression analysis may be based on fixed or mixed effect estimators, again to be distinguished into pooled WLS and cluster econometric methods. As shown by Bijmolt and Pieters (2001) using random effects cluster estimation techniques which take account of the presumed dependence problem resulting from multiple sampling in meta-analysis might be advisable. We choose among different methodological options on the basis of appropriate tests.

The remainder of the paper is organized as follows: In Section 2, we provide a qualitative review of the empirical literature followed by a description of the data set derived thereof in Section 3 and the descriptive statistics of the studies in Section 4. A classical meta-analysis follows in Section 5, while Section 6 contains the meta-regression results. Concluding remarks follow in Section 7.

\section{A Qualitative Review of the Empirical Literature}

Since the early 1980s, a rich empirical literature has evolved disentangling determinants of FDI with a special focus on the effects of company taxation. Following Devereux (2006), the empirical literature on the effects of taxes on FDI allocation can be classified along three dimensions: the type of data used (time series, cross-section, panel data), the level of aggregation, and the stage of transnational investment decision analyzed in the relevant studies. In a strict sense the decision stage dimension only becomes relevant in studies based on micro 
data; only these are able to separately analyze discrete and continuous investment choices. However, in accordance with De Mooij and Ederveen (2003) we use a slightly more general classification and distinguish studies which explicitly examine discrete location choices from studies using some sort of continuous capital data as dependent variable. ${ }^{4}$ Consequently, each study can be assigned to one of 18 possible categories (Figure 1). It should, however, be noted that not all imaginable combinations of study dimensions have been realized in the past.

\section{Figure 1: Dimensions of empirical literature on FDI and taxation}

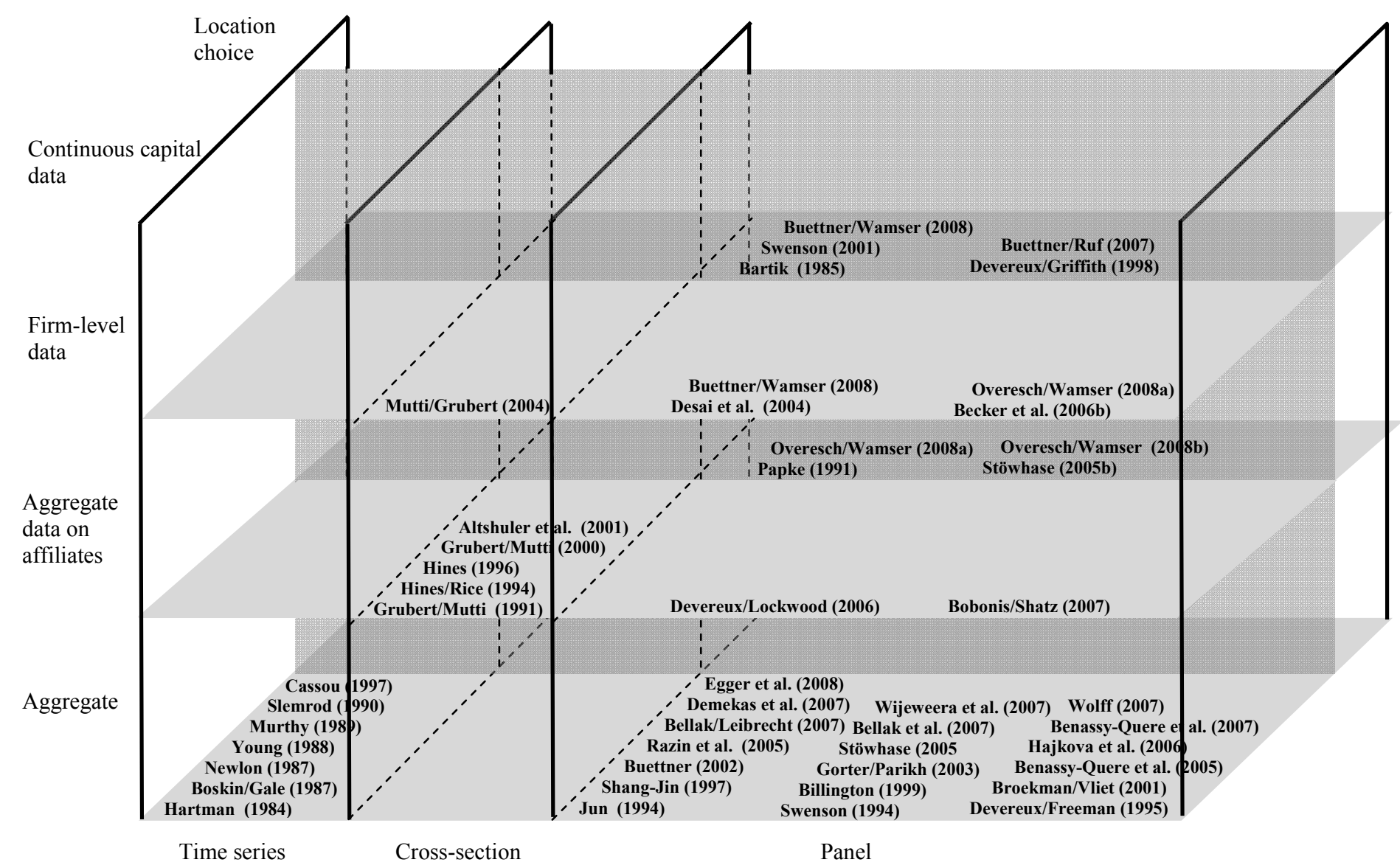

\subsection{Time Series Analysis on Aggregate FDI}

Pioneering studies in FDI research used aggregate time series data (see Table 1). They examined the correlation of relative after-tax rates of return on U.S. investments and the annual volume of inward FDI flows. ${ }^{5}$ This early approach by Hartman (1984) has been picked up by researchers, which used longer time series and varied the underlying data as well as the specifications (Boskin and Gale 1987, Newlon 1987, Young 1988, Murthy 1989). However, mod-

4. Micro studies using such capital data indeed analyse continuous investment decisions while studies based on aggregate capital data generally compound location and continuous investment decisions.

5. For surveys that cover this strand of the literature in more detail see Hines (1997, 1999), De Mooij and Ederveen (2003) and Bloningen (2005). 
ifications did not lead to differing results as compared to Hartman (1984). The established elasticities with respect to after-tax rates of return did not exceed 0.5 in the case of transfers of funds and ranging at around 1.5 for retained earnings. Only when Slemrod (1990) fundamentally reconsidered the research done so far and, inter alia, put forward new controls as well as a forward-looking tax measure, doubts were cast on previous results. Retained earnings were not affected by taxes while transfers of funds showed significant reactions. In addition, separately analyzing bilateral U.S. inward FDI from seven countries that differ in their regimes of double taxation relief - as done by Slemrod - did not yield clear-cut insights about the influence of home country taxation on the tax sensitivity of FDI flows. Following Slemrod's work, Cassou (1997) is the latest paper to perform single time series analysis on bilateral FDI. Based on a sample of six investing countries, he also constructed a panel and found a significantly negative impact of the corporate tax rate on inward FDI.

Table 1: Empirical studies using aggregate time series data

\begin{tabular}{|c|c|c|c|c|c|}
\hline Study & Data & Special Remarks & $\begin{array}{c}\text { Tax } \\
\text { Measure }\end{array}$ & Method & Main results \\
\hline Hartman (1984) & $\begin{array}{l}\text { US aggregate FDI } \\
\text { inflow , 1965-1979 }\end{array}$ & $\begin{array}{l}\text { Annual inward FDI regressed on } \\
\text { relative after-tax rates of return, } \\
\text { transfers vs. retained earnings }\end{array}$ & $\mathrm{BL}$ & OLS & $\begin{array}{l}\text { Elasticities with respect to } \\
\text { after-tax rates of return do } \\
\text { not exceed } 0.5 \text { (transfers) } \\
\text { and } 1.5 \text { (retained earnings). }\end{array}$ \\
\hline $\begin{array}{l}\text { Boskin and Gale } \\
\text { (1987) }\end{array}$ & $\begin{array}{l}\text { US aggregate FDI } \\
\text { inflow, } 1956-1984\end{array}$ & $\begin{array}{l}\text { Extending Hartman (1984) with } \\
\text { alternative data on rate of return }\end{array}$ & $\mathrm{BL}$ & OLS & $\begin{array}{l}\text { Results in accordance with } \\
\text { Hartman (1984) }\end{array}$ \\
\hline Newlon (1987) & $\begin{array}{l}\text { US aggregate FDI } \\
\text { inflow, 1956-1984 }\end{array}$ & $\begin{array}{l}\text { Criticizing Hartman (1984), coping } \\
\text { with spurious correlation }\end{array}$ & $\mathrm{BL}$ & OLS & $\begin{array}{l}\text { Results in accordance with } \\
\text { Hartman (1984) }\end{array}$ \\
\hline Young (1988) & $\begin{array}{l}\text { US aggregate FDI } \\
\text { inflow, } 1953-1984\end{array}$ & $\begin{array}{l}\text { Extending Hartman (1984), with } \\
\text { lagged investment }\end{array}$ & $\mathrm{BL}$ & OLS & $\begin{array}{l}\text { Results in accordance with } \\
\text { Hartman (1984) }\end{array}$ \\
\hline Murthy (1989) & $\begin{array}{l}\text { US aggregate FDI } \\
\text { inflow, } 1953-1984\end{array}$ & $\begin{array}{l}\text { Re-estimating Young (1988), with } \\
\text { adjustment for autocorrelation }\end{array}$ & $\mathrm{BL}$ & ML Estimator & $\begin{array}{l}\text { New funds show elastic } \\
\text { reactions with absolute } \\
\text { elasticity greater } 1 . \text { Re- } \\
\text { tained earnings also are } \\
\text { more elastic than Young } \\
\text { suggests. }\end{array}$ \\
\hline Slemrod (1990) & $\begin{array}{l}\text { Bilateral US inbound } \\
\text { FDI from } 7 \text { countries, } \\
\text { 1956-1987 }\end{array}$ & $\begin{array}{l}\text { Dummies reflecting time elapsed } \\
\text { since benchmark year, forward- } \\
\text { looking tax burden measure, con- } \\
\text { trolling for home taxes and home } \\
\text { country double taxation relief }\end{array}$ & $\mathrm{BL}, \mathrm{FL}$ & OLS & $\begin{array}{l}\text { No tax effect for retained } \\
\text { earnings, while transfers } \\
\text { showed significant reac- } \\
\text { tions. No clear insights } \\
\text { about the influence of home } \\
\text { country taxation. }\end{array}$ \\
\hline Cassou (1997) & $\begin{array}{l}\text { Bilateral US inbound } \\
\text { FDI from } 7 \text { countries, } \\
1970-1989\end{array}$ & $\begin{array}{l}\text { Time series analysis, then extend- } \\
\text { ing Slemrod (1990) to panel data } \\
\text { analysis, but no control for double } \\
\text { taxation relief system }\end{array}$ & $\mathrm{BL}$ & $\begin{array}{l}\text { OLS, home } \\
\text { country dummies } \\
\text { (when panel) }\end{array}$ & $\begin{array}{l}\text { A significantly negative } \\
\text { impact of the corporate tax } \\
\text { rate on inward FDI was } \\
\text { identified. }\end{array}$ \\
\hline
\end{tabular}

Tax measures: Backward looking tax measures (BL), Forward looking tax measures (FL)

Source: Own Compilation.

\subsection{Panel Data Analysis on Aggregate FDI}

The idea of using panel data on bilateral FDI flows goes back to Devereux and Freeman (1995) (see Table 2). Their sample included 7 OECD countries in the period from 1985 to 1989. As a further innovation, Devereux and Freeman (1995) introduced bilateral cost of capital into their analysis reflecting the country-pair-specific effective marginal tax burden on 
transnational investments. They found that location choice is indeed affected by taxation. Since then, bilateral FDI flows or positions have remained a commonly used basis for subsequent research. ${ }^{6}$ For a long time, Buettner (2002) is the only one using bilateral cost of capital while most of the other studies based on bilateral FDI rely on unilateral tax measures. ${ }^{7}$ Drawing on a panel of intra-EU transfers of funds between 1991 and 1998, Buettner also includes statutory corporate income tax rates into his regressions thus attempting to catch some effects of infra-marginal, i.e. localization-relevant, considerations. From a (joint) significance of both, the effective marginal tax burden (EMTR) and the statutory tax rate (STR), he infers an impact of the effective average tax rate (EATR) in the determination of FDI. Another noteworthy result is that explicitly controlling for the supply of public services does not reveal an important impact of public expenditures on locational attractiveness.

Gorter and Parikh (2003) collect OECD panel data of bilateral FDI positions. While they do not analyze the joint effect of distinct tax measures, they separately analyze the effects of the unilateral host country EMTR and of a backward-looking average tax rate computed on the basis of micro data. The tax effects are significantly negative, but provide ambiguous evidence for the home country system of international double taxation relief by means of a restricted SUR model. While restricted regressions that employ the micro average tax rate (Micro ATR) substantiate zero tax elasticity for credit countries (U.K.), the corresponding EMTR regressions suggest no particular relief system-specific impact on FDI. Stöwhase (2005a) draws on bilateral FDI from 8 EU countries to Germany, the Netherlands and the UK between 1995 and 1999. He shows that only the secondary and tertiary sectors are sensitive to taxation while the primary sector is not. Bénassy-Quéré et al. (2005) employ various, i.e. forwardlooking, backward-looking and statutory tax measures without revealing fundamental differences in the implied tax sensitivity of FDI. The effects they calculate on the basis of their panel of intra-OECD bilateral FDI flows between 1984 and 2000 are generally negative and significant. Interestingly, by controlling for the amount and the composition of public expenditures, Bénassy-Quéré et al. (2005) find a positive composition effect, i.e. a higher share of investment in public expenditures adds to locational attractiveness and weakens tax effects.

Bellak et al. (2007) even make an attempt to test Tiebout's intuition. Based on a panel of bilateral outward FDI flows of seven home countries to eight Central and Eastern European Countries (CEEC) for the period from 1995 to 2004, they explicitly control for a possible in-

6. Panel studies using aggregate non-bilateral data are Jun (1994), Swenson (1994), Billington (1999), Broekman and van Vliet (2001).

7. Devereux and Freeman (1995) provide the bilateral costs of capital employed by Buettner (2002). 
terrelation between bilateral effective average tax rates (BEATR) and infrastructure as determinants of FDI. Their results provide evidence that infrastructure - especially a good endowment of communication facilities - positively influences FDI; this is directed towards the respective country and may even compensate for higher taxes. Demekas et al. (2007) also include a proxy for infrastructure into their study. Their panel analysis of aggregate FDI-flows between 16 home countries and 24 CEECs during the period 1995 - 2003, which is not meant to finance privatization-related projects, employs the statutory corporate income tax rate as a measure of company tax burden. Based on this data set, they conclude that infrastructure determines the attractiveness of developing countries, although this is not valid for countries that have reached a higher stage of economic development. Moreover, their reported tax effects are mainly significant. Bénassy-Quéré et al. (2005) examine US foreign investment in $18 \mathrm{EU}$ countries from 1994 - 2003. They assume a trade-off between public spending and the tax rate; public spending as well as a lower tax rate can increase FDI. Their findings confirm their assumption. They emphasize that it is not desirable to participate in fierce tax competition because of negative spillovers, such as lost funding for public goods. However, they argue that tax competition leads to a relocation to more efficient public goods. Wijeweera et al. (2007) employ an OECD panel data set of FDI from nine source countries investing in the U.S. during the period from 1982 to 2000 . They include various controls into their regressions which separately resort to forward-looking marginal as well as infra-marginal tax measures as well as to the statutory tax rate. The measured tax effects are more robust for the statutory tax rates as for the effective tax measures. Controlling for infrastructure yields mainly insignificant coefficients, which are explained by the generally high level of economic development and, thus, infrastructure endowment of all home countries included in the panel.

Bellak and Leibrecht (2007) concentrate on Central and Eastern Europe as the target for FDI flows. They use panel data on bilateral FDI flows from seven home countries to eight CEECs for the time span from 1995 to 2003. The authors integrate both, EMTR as well as the EATR, into their analysis. Furthermore, like Bellak, Leibrecht and Damijan (2007), they belong to the relatively few studies that do not rely on simple unilateral measures which only reflect host country specific tax legislation explicitly referring to bilateral measures. Their results indicate that FDI-flows to CEECs are primarily determined by bilateral effective tax rates (BEATR). Bellak and Leibrecht (2007) argue that this is due to the predominance of new and inframarginal investment projects in these transition economies. Hajkova et al. (2006) use BEATR in their regressions drawing on a panel of bilateral intra-OECD FDI-stocks over the 1990s. They apply the transformed least squares approach introduced by Erkel-Rousse and 
Mirza (2002) which allows to control for unobserved heterogeneity specific for each home country, host country and home-host country pair. Generally, they report rather small tax elasticities. The authors explain this result by dint of their very broad set of policy controls. Egger et al. (2008) particularly focus on the interrelation of bilateral and unilateral effective tax rates. Based on a panel of outbound positions of bilateral intra-OECD FDI between 1991 and 2002, Egger et al. (2008) show that the estimated impact of the host country unilateral tax rate turns positive, when the bilateral tax rate is additionally considered. This reflects the ceterisparibus-advantage of multinationals over competing domestic firms in case of rising unilateral host country tax rates. The coefficient of the bilateral tax rates, however, is robustly negative as it translates the direct negative impact on after-tax returns of transnational investments.

Table 2: Empirical studies using aggregate panel data

\begin{tabular}{|c|c|c|c|c|c|}
\hline Study & Data & Special Remarks & $\begin{array}{c}\text { Tax } \\
\text { Measure }\end{array}$ & Method & Main results \\
\hline Jun (1994) & $\begin{array}{l}\text { US aggregate in- } \\
\text { bound FDI from } \\
\text { OECD countries, } \\
1980-1989\end{array}$ & $\begin{array}{l}\text { Controlling for } \\
\text { home country } \\
\text { system of double } \\
\text { taxation relief }\end{array}$ & $\mathrm{BL}, \mathrm{FL}$ & $\begin{array}{l}\text { Fixed effects : } \\
\text { OLS, GLS, } \\
\text { country dummies }\end{array}$ & $\begin{array}{l}\text { The home country's statutory tax rate } \\
\text { has a significant negative effect on } \\
\text { FDI from countries with residence } \\
\text { systems, but not on FDI from terri- } \\
\text { torial systems. }\end{array}$ \\
\hline Swenson (1994) & $\begin{array}{l}\text { Bilateral US } \\
\text { inbound PPE } \\
\text { investments, } \\
\text { 1979-1991 }\end{array}$ & $\begin{array}{l}\text { Exploiting US tax } \\
\text { history of the } \\
\text { 1980s, focusing on } \\
\text { industry variation } \\
\text { (18 industries) }\end{array}$ & $\mathrm{BL}, \mathrm{FL}$ & $\begin{array}{l}\text { OLS, GLS, } \\
\text { industry dum- } \\
\text { mies, time trend }\end{array}$ & $\begin{array}{l}\text { Foreign investment in the US is tax } \\
\text { sensitive. Average tax rates are more } \\
\text { precise indicators for the effects than } \\
\text { effective tax rate measures. }\end{array}$ \\
\hline $\begin{array}{l}\text { Devereux and Free- } \\
\text { man (1995) }\end{array}$ & $\begin{array}{l}\text { Bilateral FDI, } \\
7 \text { OECD coun- } \\
\text { tries, } 1985-1989\end{array}$ & $\begin{array}{l}\text { Bilateral effective } \\
\text { tax burden measure }\end{array}$ & FL & $\begin{array}{l}\text { Fixed Effects: } \\
\text { IV, OLS, time } \\
\text { and country-pair } \\
\text { dummies or FD } \\
\text { estimator }\end{array}$ & $\begin{array}{l}\text { Location choice is affected by taxa- } \\
\text { tion. Granting tax credit for foreign } \\
\text { shareholders may lead to an increase } \\
\text { of inbound FDI from exemption } \\
\text { countries. }\end{array}$ \\
\hline Billington (1999) & $\begin{array}{l}\text { Aggregate in- } \\
\text { bound FDI, G7- } \\
\text { countries, } 11 \text { UK } \\
\text { regions, } 1986 \text { - } \\
1983\end{array}$ & & STR & OLS & $\begin{array}{l}\text { The statutory corporate tax rate has a } \\
\text { significantly negative effect on FDI } \\
\text { inflow. }\end{array}$ \\
\hline Shang-Jin (1997) & $\begin{array}{l}\text { Bilateral FDI, } \\
\text { from } 14 \text { source to } \\
46 \text { host countries, } \\
1990-1991\end{array}$ & $\begin{array}{l}\text { Explicitly control- } \\
\text { ling for corruption }\end{array}$ & $\mathrm{BL}$ & $\begin{array}{l}\text { (Quasi-)Fixed } \\
\text { Effects: OLS, IV, } \\
\text { source country } \\
\text { dummies }\end{array}$ & $\begin{array}{l}\text { A rise of the tax rate as well as a rise } \\
\text { in corruption leads to a reduction of } \\
\text { inward FDI. U.S. investors are not } \\
\text { significantly more averse to corrup- } \\
\text { tion than are average OECD- } \\
\text { investors. }\end{array}$ \\
\hline $\begin{array}{l}\text { Broekman and Vliet } \\
\text { (2001) }\end{array}$ & $\begin{array}{l}\text { Aggregate EU } \\
\text { inbound FDI, } \\
\text { 1989-1998 }\end{array}$ & & $\mathrm{BL}$ & $\begin{array}{l}\text { Fixed Effects: } \\
\text { OLS, time dum- } \\
\text { mies, host coun- } \\
\text { try dummies. }\end{array}$ & $\begin{array}{l}\text { There is a significant relation between } \\
\text { effective tax rates and FDI with a tax } \\
\text { elasticity of } 0.5 \text {. }\end{array}$ \\
\hline Buettner (2002) & $\begin{array}{l}\text { Bilateral FDI } \\
\text { financed by } \\
\text { transfers, EU 15, } \\
1991-1998\end{array}$ & $\begin{array}{l}\text { Effects of statutory } \\
\text { and effective mar- } \\
\text { ginal tax burden } \\
\text { analysed jointly to } \\
\text { capture average } \\
\text { effective tax bur- } \\
\text { den. Controlling for } \\
\text { public services. }\end{array}$ & $\begin{array}{l}\text { BL, FL, } \\
\text { STR }\end{array}$ & $\begin{array}{l}\text { Fixed Effects: } \\
\text { OLS, IV, home } \\
\text { and host country } \\
\text { dummies or FE } \\
\text { estimator. } \\
\text { Random Effects. } \\
\text { Always: Time } \\
\text { dummies. }\end{array}$ & $\begin{array}{l}\text { The effective average tax burden } \\
\text { significantly determines FDI. Public } \\
\text { services do not seem to have an } \\
\text { important impact on locational attrac- } \\
\text { tiveness. }\end{array}$ \\
\hline $\begin{array}{l}\text { Gorter and Parikh } \\
(2003)\end{array}$ & $\begin{array}{l}\text { Bilateral FDI } \\
\text { positions, } \\
\text { EU 15, 1995- } \\
1996\end{array}$ & $\begin{array}{l}\text { Extending Hines } \\
\text { (1996) }\end{array}$ & $\mathrm{BL}, \mathrm{FL}$ & OLS, SUR & $\begin{array}{l}\text { Tax effects on FDI are significantly } \\
\text { negative. Accounting for the home } \\
\text { country system of international double } \\
\text { taxation relief provides ambiguous } \\
\text { evidence. }\end{array}$ \\
\hline
\end{tabular}


Table 2 (cont.): Empirical studies aggregate panel data

\begin{tabular}{|c|c|c|c|c|c|}
\hline Study & Data & Special Remarks & $\begin{array}{c}\text { Tax } \\
\text { Measure }\end{array}$ & Method & Main results \\
\hline $\begin{array}{l}\text { Bénassy-Quéré et al. } \\
(2005)\end{array}$ & $\begin{array}{l}\text { Bilateral FDI, } 11 \\
\text { OECD countries, } \\
1984-2000\end{array}$ & $\begin{array}{l}\text { Various specifica- } \\
\text { tions, controls and } \\
\text { tax burden meas- } \\
\text { ures. }\end{array}$ & $\begin{array}{l}\text { BL, FL, } \\
\text { STR }\end{array}$ & $\begin{array}{l}\text { Fixed Effects: } \\
\text { OLS, IV, home } \\
\text { and host country } \\
\text { dummies }\end{array}$ & $\begin{array}{l}\text { Tax effects are generally significantly } \\
\text { negative. A higher share of invest- } \\
\text { ment in public expenditures weakens } \\
\text { tax effects. }\end{array}$ \\
\hline Razin et al. (2005) & $\begin{array}{l}\text { Bilateral FDI, } 24 \\
\text { OECD countries, } \\
1981-1998\end{array}$ & $\begin{array}{l}\text { 2-stage investment } \\
\text { decision analyzed } \\
\text { with macroeconom- } \\
\text { ic data }\end{array}$ & STR & $\begin{array}{l}\text { Heckman selec- } \\
\text { tion: Probit, } \\
\text { OLS, time and } \\
\text { country dummies }\end{array}$ & $\begin{array}{l}\text { Source-country statutory tax rate } \\
\text { plays an important role in the selec- } \\
\text { tion process, whereas the host country } \\
\text { tax rate affects the scale of invest- } \\
\text { ment. }\end{array}$ \\
\hline Stöwhase (2005a) & $\begin{array}{l}\text { Bilateral FDI, } \\
\text { from } 8 \text { EU coun- } \\
\text { tries to Germany, } \\
\text { Netherlands and } \\
\text { UK, 1995-1999 }\end{array}$ & $\begin{array}{l}\text { Investments diffe- } \\
\text { rentiated by three } \\
\text { main economic } \\
\text { sectors }\end{array}$ & $\mathrm{BL}, \mathrm{FL}$ & $\begin{array}{l}\text { Fixed Effects: } \\
\text { GLS, SUR, } \\
\text { country-pair } \\
\text { dummies and } \\
\text { time dummies. }\end{array}$ & $\begin{array}{l}\text { Tax sensitivity of FDI varies between } \\
\text { economic sectors. Only the secondary } \\
\text { and tertiary sectors are sensitive to } \\
\text { high tax rates. }\end{array}$ \\
\hline Haijkova et al. (2006) & $\begin{array}{l}\text { Bilateral FDI } \\
\text { stocks, } 28 \text { OECD } \\
\text { countries, } 1991 \text { - } \\
2000\end{array}$ & $\begin{array}{l}\text { Fully controlling } \\
\text { for unobserved } \\
\text { heterogeneity }\end{array}$ & FL, STR & $\begin{array}{l}\text { Fixed Effects: FE } \\
\text { estimator, Trans- } \\
\text { formed Least } \\
\text { Squares (TLS) }\end{array}$ & $\begin{array}{l}\text { Generally rather small tax elasticities } \\
\text { are reported, presumably due to a very } \\
\text { broad set of policy controls. }\end{array}$ \\
\hline $\begin{array}{l}\text { Bellak and Leibrecht } \\
\text { (2007) }\end{array}$ & $\begin{array}{l}\text { Bilateral FDI, } 7 \\
\text { home to } 8 \text { CEE } \\
\text { countries, } 1995 \text { - } \\
2003\end{array}$ & $\begin{array}{l}\text { Bilateral forward- } \\
\text { looking tax burden } \\
\text { measures }\end{array}$ & FL & $\begin{array}{l}\text { Random Effects, } \\
\text { time dummies. } \\
\text { Fixed Effects: FE } \\
\text { Estimator. }\end{array}$ & $\begin{array}{l}\text { FDI into CEECs is primarily deter- } \\
\text { mined by the bilateral effective aver- } \\
\text { age tax burden. }\end{array}$ \\
\hline Bellak et al. (2007) & $\begin{array}{l}\text { Bilateral FDI, } 7 \\
\text { home to } 8 \text { CEE } \\
\text { countries, } 1995 \text { - } \\
2004\end{array}$ & $\begin{array}{l}\text { Controlling for } \\
\text { infrastructure, } \\
\text { bilateral forward- } \\
\text { looking tax burden } \\
\text { measures }\end{array}$ & FL & $\begin{array}{l}\text { Random Effects, } \\
\text { time dummies }\end{array}$ & $\begin{array}{l}\text { Infrastructure - especially communi- } \\
\text { cation facilities - positively influences } \\
\text { FDI and may compensate for higher } \\
\text { taxes. }\end{array}$ \\
\hline $\begin{array}{l}\text { Bénassy-Quéré et al. } \\
\text { (2007) }\end{array}$ & $\begin{array}{l}\text { Bilateral US } \\
\text { outbound PPE } \\
\text { stock in } 18 \text { EU } \\
\text { countries, } 1994- \\
1999 \text { or } 2003\end{array}$ & $\begin{array}{l}\text { Testing if the } \\
\text { provision of public } \\
\text { goods changes the } \\
\text { tax-sensitivity of } \\
\text { FDI }\end{array}$ & FL, STR & $\begin{array}{l}\text { Fixed Effects: } \\
\text { OLS, country } \\
\text { and/or sector } \\
\text { dummies, alter- } \\
\text { natively FD } \\
\text { Estimation }\end{array}$ & $\begin{array}{l}\text { The provision of public goods does } \\
\text { affect location choice. } \\
\text { The increase of public capital by } \\
\text { means of higher tax rate though can } \\
\text { have negative effects on inward FDI- } \\
\text { flows. }\end{array}$ \\
\hline $\begin{array}{l}\text { Wijeweera et al. } \\
(2007)\end{array}$ & $\begin{array}{l}\text { Bilateral US } \\
\text { inbound FDI } \\
\text { from } 9 \text { OECD } \\
\text { countries, } 1982 \text { - } \\
2000\end{array}$ & $\begin{array}{l}\text { Extending Slemrod } \\
(1990) \text { to panel data } \\
\text { analysis }\end{array}$ & FL, STR & $\begin{array}{l}\text { Fixed Effects: } \\
\text { OLS, GLS, } \\
\text { country dum- } \\
\text { mies, time trend }\end{array}$ & $\begin{array}{l}\text { Tax effects are more robust for the } \\
\text { statutory tax rates as for the effective } \\
\text { tax measures. Coefficients for infra- } \\
\text { structure are mainly insignificant, } \\
\text { presumably due to the high level of } \\
\text { economic development of all coun- } \\
\text { tries considered. }\end{array}$ \\
\hline Demekas et al. (2007) & $\begin{array}{l}\text { Aggregate FDI, } \\
16 \text { home to } 24 \\
\text { CEE countries, } \\
1995-2003\end{array}$ & $\begin{array}{l}\text { Threshold effect } \\
\text { estimation with } \\
\text { respect to income } \\
\text { levels, non- } \\
\text { privatization FDI }\end{array}$ & STR & $\begin{array}{l}\text { Fixed Effects: } \\
\text { S- GMM, time } \\
\text { dummies }\end{array}$ & $\begin{array}{l}\text { Apart from gravity factors, FDI in } \\
\text { European transition economies is } \\
\text { influenced by a broad set of host } \\
\text { country policies. }\end{array}$ \\
\hline Wolff (2007) & $\begin{array}{l}\text { Bilateral FDI, } \\
\text { EU } 27 \text { (excl. } \\
\text { Romania), } 1994 \text { - } \\
2003\end{array}$ & $\begin{array}{l}\text { Extending Razin et } \\
\text { al. (2005), distin- } \\
\text { guishing total FDI, } \\
\text { equity and debt } \\
\text { transfers }\end{array}$ & STR & $\begin{array}{l}\text { Heckman selec- } \\
\text { tion: Probit, } \\
\text { OLS, time and } \\
\text { country dummies }\end{array}$ & $\begin{array}{l}\text { Results are mixed: For total and } \\
\text { equity FDI no robustly significant tax } \\
\text { effects are reported. }\end{array}$ \\
\hline Egger et al. (2008) & $\begin{array}{l}\text { Bilateral FDI, } 22 \\
\text { source to } 26 \text { host } \\
\text { countries } \\
\text { (OECD), } 1991 \text { - } \\
2002\end{array}$ & $\begin{array}{l}\text { Focus on the inter- } \\
\text { relation of uni- and } \\
\text { bilateral forward- } \\
\text { looking tax burden } \\
\text { measures }\end{array}$ & FL & $\begin{array}{l}\text { Fixed Effects: FE } \\
\text { estimator, GMM, } \\
\text { time dummies }\end{array}$ & $\begin{array}{l}\text { FDI reacts positively to the parent and } \\
\text { host country tax rate and negatively to } \\
\text { bilateral effective tax rate. Isolated } \\
\text { unilateral tax rates can lead to biases } \\
\text { results. }\end{array}$ \\
\hline
\end{tabular}

Tax measures: Backward looking tax measures (BL), Forward looking tax measures (FL), Statutory tax rates (STR)

Source: Own Compilation. 
As Devereux (2006) points out, FDI-flows (or the resulting positions) rather describe one method to finance expansion and do not correspond precisely to any specific stage of the overall investment decision. However, Razin et al. (2005) apply the idea of two sequential decisions - how much to invest conditional on the discrete decision to invest at all - even to bilateral macroeconomic FDI data. They analyze bilateral panel data with 24 OECD countries over the period 1981 to 1998 and address the underlying sample selection problem by the Heckman selection method. Thereby, they do not focus on marginal versus infra-marginal effective tax measures, but on home and host country STRs. Their results indicate that the source-country statutory tax rate is an important factor in the selection process, whereas the host-country tax rate affects the scale of investment. Wolff (2007) closely follows Razin et al. (2005) in his empirical approach. He draws on a panel of bilateral FDI flows for the EU 27 countries (excluding Romania) for the period 1994 - 2003 and runs regressions for total FDI as well as equity FDI, inter-company debt transactions and retained earnings. His results are mixed. For total and equity FDI no robust significant tax effects are reported.

\subsection{Studies Using Aggregate Data on Affiliates of Multinational Companies}

\subsubsection{Location Choice: Count Data Models}

Papke (1991) applies a Poisson count model estimated via maximum likelihood techniques in order to analyze the tax sensitivity of location choices (see Table 3). Count data models imply the aggregation of the number of considered companies' affiliates per host country. Papke (1991) draws on a panel of plant birth data built from cross-sections of the US Establishment and Enterprise Microdata File (USEEM) for the years 1976, 1978, 1980 and 1982. Thereby, she is among the first to use a forward-looking tax burden measure. Her results show that economic factors such as taxes play a significant role in the determination of manufacturing locations, although responsiveness differs considerably across industries. Stöwhase (2005b) also relies on count data, but rejects the Poisson model in favor of a negative Binomial model due to less restrictive assumptions. His data set is based on data covering the foreign engagements of German multinationals for the period 1991 to 1998 . He shows that real activity is significantly deterred by rising effective tax burdens, while management and finance as well as research and development (R\&D) activities only react negatively to statutory tax rates.

Overesch and Wamser (2008a) examine MiDi-data for the time from 1996 to 2005 and focus on German investments in eastern European EU accession countries. The Poisson count model proves to be applicable for the analysis of location decisions. The negative Binomial model is only a viable alternative if country fixed effects are included. Under both models the STR 
exerts a significant impact on the expected number of German affiliates in a certain host country. Moreover, the EATR proves to be the more suitable indicator for tax effects in contrast to the EMTR. Controlling for infrastructure yields significant coefficients as expected in transition economies. Overesch and Wamser (2008b) use Midi-data for German outbound investments in 30 European countries for the period from 1989 to 2005 and study asymmetries with respect to tax sensitivities originating from different motivations to internationalize, different degrees of internationalization and different business activities of firms. On the basis of a negative Binomial count model, they show that vertical FDI in manufacturing is significantly more responsive to local taxation than horizontal FDI. Financial service and R\&D activities are highly tax sensitive as well as affiliates of an only weakly internationalized firm.

Table 3: Empirical studies using count data

\begin{tabular}{|c|c|c|c|c|c|}
\hline Study & Data & Special Remarks & $\begin{array}{c}\text { Tax } \\
\text { Measure }\end{array}$ & Method & Main results \\
\hline Papke (1991) & $\begin{array}{l}\text { Data on plant births in US } \\
\text { states, } 1976+1978+ \\
1980+1982\end{array}$ & $\begin{array}{l}\text { Distinguishing between } \\
\text { different industries }\end{array}$ & FL & $\begin{array}{l}\text { ML Estimation } \\
\text { (Poisson count } \\
\text { model), state fixed } \\
\text { effects }\end{array}$ & $\begin{array}{l}\text { Economic factors, e.g. } \\
\text { taxes play a significant } \\
\text { role in manufacturing } \\
\text { locations, but impact } \\
\text { differs across industries. }\end{array}$ \\
\hline Stöwhase (2005b) & $\begin{array}{l}\text { Microdata on German } \\
\text { multinationals' activities } \\
\text { in } 8 \text { EU countries, } 1984 \text { - } \\
1994\end{array}$ & $\begin{array}{l}\text { Differentiating between } \\
\text { functional forms of engage- } \\
\text { ments }\end{array}$ & BL, STR & $\begin{array}{l}\text { GLS }(\mathrm{NegBin} \\
\text { count model) }\end{array}$ & $\begin{array}{l}\text { Real activities are signifi- } \\
\text { cantly deterred by rising } \\
\text { average tax burdens, while } \\
\text { management, finance and } \\
\text { R\&D reacts negatively } \\
\text { only to statutory tax rates. }\end{array}$ \\
\hline $\begin{array}{l}\text { Overesch and } \\
\text { Wamser (2008a) }\end{array}$ & $\begin{array}{l}\text { Microdata on German } \\
\text { multinationals' activities } \\
\text { in EU 8,1996- } 2005 \\
\text { (MiDi) }\end{array}$ & $\begin{array}{l}\text { Inter alia controlling for } \\
\text { infrastructure }\end{array}$ & FL, STR & $\begin{array}{l}\text { ML Estimation } \\
\text { (NegBin and fixed } \\
\text { effects: Poisson } \\
\text { model), time } \\
\text { dummies. }\end{array}$ & $\begin{array}{l}\text { The host statutory tax rate } \\
\text { exerts a significant impact } \\
\text { on location choice, but the } \\
\text { EATR is most suitable to } \\
\text { measure tax effects. } \\
\text { Infrastructure shows } \\
\text { significant coefficients. }\end{array}$ \\
\hline $\begin{array}{l}\text { Overesch and } \\
\text { Wamser }(2008 b)\end{array}$ & $\begin{array}{l}\text { Microdata on German } \\
\text { multinationals' activities } \\
\text { in } 30 \text { European countries, } \\
1989 \text { - } 2005(\mathrm{MiDi})\end{array}$ & $\begin{array}{l}\text { Focus on tax asymmetries: } \\
\text { motivation, activity, degree } \\
\text { of internationalization }\end{array}$ & FL, STR & $\begin{array}{l}\text { ML Estimation } \\
\text { (NegBin count } \\
\text { model), time } \\
\text { dummies }\end{array}$ & $\begin{array}{l}\text { Host-country taxation has } \\
\text { a higher impact on verti- } \\
\text { cally than on horizontally } \\
\text { integrated FDI. }\end{array}$ \\
\hline
\end{tabular}

Tax measures: Backward looking tax measures (BL), Forward looking tax measures (FL), Statutory tax rates (STR)

Source: Own Compilation.

\subsubsection{Continuous Capital Data: Studies Using Aggregate PPE Stocks}

The early study by Grubert and Mutti (1991) relies on cross-sectional data from the Bureau of Economic Activity (BEA), US Department of Commerce (see Table 4). These data are based on the level of the capital (PPE) stock of affiliates of US multinational companies in specific foreign countries. Grubert and Mutti (1991) report an important effect of taxes as well as tariffs on the international capital allocation. Based on similar data with its focus on tax haven countries, Hines and Rice (1994) find a very high negative influence of taxes on PPE positions which are higher than the estimates by Grubert and Mutti (1991). Devereux and Lockwood (2006) draw on the same data source as Grubert and Mutti (1991) and Hines and Rice 
(1994) using panel data, however. Devereux and Lockwood (2006) develop a two-stage model, which is estimated in a probabilistic choice framework, in order to be able to better analyze the two main elements of the decision-making process even on the basis of aggregate data. The results indicate a large and significant impact of EATR, but no impact of EMTR.

Table 4: Empirical studies using aggregate PPE data on affiliates

\begin{tabular}{|c|c|c|c|c|c|}
\hline Study & Data & Special Remarks & $\begin{array}{c}\text { Tax } \\
\text { Measure }\end{array}$ & Method & Main results \\
\hline $\begin{array}{l}\text { Grubert and Mutti } \\
\text { (1991) }\end{array}$ & $\begin{array}{l}\text { PPE stock of US affili- } \\
\text { ates in } 33 \text { foreign coun- } \\
\text { tries, } 1982\end{array}$ & $\begin{array}{l}\text { Considering host country } \\
\text { taxes as well as tariffs }\end{array}$ & BL & OLS & $\begin{array}{l}\text { Taxes and tariffs signifi- } \\
\text { cantly determine interna- } \\
\text { tional capital allocation. }\end{array}$ \\
\hline $\begin{array}{l}\text { Hines and Rice } \\
\text { (1994) }\end{array}$ & $\begin{array}{l}\text { PPE stock of US affiliates } \\
\text { in } 73 \text { foreign locations, } \\
1982\end{array}$ & Special focus on tax havens & BL & OLS, IV & $\begin{array}{l}\text { A high negative influence } \\
\text { of taxes on PPE positions } \\
\text { is reported, exceeding the } \\
\text { estimates of Grubert and } \\
\text { Mutti (1991). }\end{array}$ \\
\hline Hines (1996) & $\begin{array}{l}\text { US state-specific PPE } \\
\text { stock of affiliates from } 7 \\
\text { foreign countries, } 1987\end{array}$ & $\begin{array}{l}\text { Central Idea: Non-uniform } \\
\text { distribution of activities } \\
\text { across states from credit } \\
\text { countries captures all non- } \\
\text { tax state-specific factors }\end{array}$ & STR & Tobit & $\begin{array}{l}\text { There are large negative } \\
\text { tax effects in the determi- } \\
\text { nation of foreign direct } \\
\text { investment. }\end{array}$ \\
\hline $\begin{array}{l}\text { Grubert and Mutti } \\
(2000)\end{array}$ & $\begin{array}{l}\text { PPE stock of US affiliates } \\
\text { in } 60 \text { foreign locations, } \\
1992\end{array}$ & & BL & OLS & $\begin{array}{l}\text { Significantly negative tax } \\
\text { elasticities are reported. }\end{array}$ \\
\hline $\begin{array}{l}\text { Altshuler et al. } \\
(2001)\end{array}$ & $\begin{array}{l}\text { PPE stock of US affiliates } \\
\text { in } 58 \text { foreign locations, } \\
1984+1992\end{array}$ & $\begin{array}{l}\text { Development of tax sensi- } \\
\text { tivity from } 1980 \mathrm{~s}-1990 \mathrm{~s}\end{array}$ & BL, STR & OLS, IV & $\begin{array}{l}\text { Capital has become more } \\
\text { responsive to taxes during } \\
\text { the } 1980 \text { s. }\end{array}$ \\
\hline $\begin{array}{l}\text { Devereux and Lock- } \\
\text { wood ( } 2006)\end{array}$ & $\begin{array}{l}\text { PPE stock of US affili- } \\
\text { ates in } 19 \text { OECD coun- } \\
\text { tries, } 1983-1998\end{array}$ & $\begin{array}{l}\text { 2-stage model integrating } \\
\text { probabilistic choice frame- } \\
\text { work }\end{array}$ & FL, STR & $\begin{array}{l}\text { Fixed Effects : } \\
\text { GMM, time and } \\
\text { country dummies }\end{array}$ & $\begin{array}{l}\text { Results indicate a large } \\
\text { and significant impact of } \\
\text { the EATR, but no impact } \\
\text { of the EMTR. }\end{array}$ \\
\hline $\begin{array}{l}\text { Bobonis and Shatz } \\
(2007)\end{array}$ & $\begin{array}{l}\text { US state-specific PPE } \\
\text { stock of affiliates from } 7 \\
\text { foreign countries, 1977- } \\
1996\end{array}$ & $\begin{array}{l}\text { Focus on agglomeration } \\
\text { effects }\end{array}$ & STR & $\begin{array}{l}\text { Fixed Effects: } \\
\text { OLS, state-home } \\
\text { dummies, GMM }\end{array}$ & $\begin{array}{l}\text { The insights as to the } \\
\text { influence of corporate } \\
\text { taxes remain only vague. } \\
\text { In contrast, agglomeration } \\
\text { effects are confirmed. }\end{array}$ \\
\hline
\end{tabular}

Tax measures: Backward looking tax measures (BL), Forward looking tax measures (FL), Statutory tax rates (STR) Source: Own Compilation.

Basically, Grubert and Mutti (2000) as well as Altshuler et al. (2001) have access to individual company tax-returns data. However, they aggregate this information on US outbound activities within each host country. Grubert and Mutti (2000) regress the amount of invested real capital by the foreign affiliates of US multinationals on ATR in about 60 host countries. They report significantly negative tax elasticities. Altshuler et al. (2001) use similar data and find out that capital has become more responsive to taxes during the 1980s. Hines (1996) uses BEA data as well, but on the US activities of foreign multinationals. He analyzes variations in the distribution of PPE between US states and identifies non-tax factors by looking at the distribution of investments from tax credit countries, restricting their tax sensitivity to zero. For exemption countries, Hines (1996) reports large and negative tax effects in the determination of FDI. Hines' approach has been adopted by following authors such as Gorter and Parikh (2003). Bobonis and Shatz (2007) use the same BEA data source as Hines (1996) on the US state-level foreign-invested capital stock. But similar to Devereux and Lockwood (2006), they 
rely on a panel covering the years from 1977 to 1996. Bobonis and Shatz (2007) resort to a dynamic specification and especially focus on agglomeration effects. The existence of such effects on PPE positions is confirmed. However, the insights about tax effects remain vague.

\subsection{Studies Using Individual Company Data}

While economists from the US have access to individual data since several years, comparable data for Europe has become available only recently. The improved availability of micro data has led to a rising number of studies, which focus on the distinct levels of the overall foreign investment decision.

\subsubsection{Location Choice: Discrete Choice Models}

Bartik (1985) was the first to employ the (nested) conditional Logit model developed by McFadden $(1974,1978)$ on microeconomic company data (see Table 5). His aim was to discern the influencing factors of discrete location choices between US states. The information on plant locations stems from a data base developed by Schmenner (1982) for the years 1972 and 1978. He reports a significant negative effect of state taxes on business location patterns. Devereux and Griffith (1998) also use a nested conditional Logit model to analyze companies' discrete decision where to produce. They find evidence that the EATR - as opposed to the EMTR - plays a significant deterring role in the location decision. This result was found on the basis of a Compustat panel for the period 1980 to 1994 covering US firms that are located in the European market. Swenson (2001) estimates a conditional Logit model as well, using panel data on discrete investment choices that were made by multinational companies from seven countries in different states of the US between 1984 and 1994. Her data set allows for distinguishing between alternative transaction types and the source country system of double taxation relief. With mergers and acquisitions (M\&A) being positively affected by rising host country taxes, some of her results, however, turn out to be rather surprising.

Mutti and Grubert (2004) employ a random effects Probit analysis based on cross-sectional individual tax returns of US multinationals investing in 60 foreign locations for the year 1996. Controlling for parent characteristics they find that especially labor intensity positively affects international mobility. At the policy level taxation is an important factor. However, its adverse effect on location decisions is weakened in high-income host countries, probably due to better infrastructure or agglomeration effects there. Buettner and Ruf (2007) opt for a fixed effects Logit model, which is based on more realistic assumptions as compared to previous studies. For example, it allows parent companies to hold more than one subsidiary abroad. 
Another virtue of this approach is that (time-invariant) heterogeneity in the firms' assessment of locations and heterogeneity of locations itself can be addressed simultaneously by means of fixed firm-specific location effects. They base their data-set on a panel of German multinationals that invest in 18 OECD countries; the panel is provided by the German Bundesbank's MiDi database and covers the time span from 1996 to 2003. Their results confirm the results of Devereux and Griffith (1998) regarding the irrelevance of the EMTR in discrete location decisions. However, in contrast to Devereux and Griffith, STR shows a stronger adverse effect on location choice as compared to the EATR, which is only weakly significant. Buettner and Ruf (2007) hypothesize that the latter result might reflect measurement problems, i.e. an imperfect fit of the employed effective tax rates to individual firms and investments. Buettner and Wamser (2008) also examine the discrete location decision by means of a fixed effects Logit model drawing on MiDi-data for 22 OECD host countries from 1996 to 2004. They report robust negative effects on the parent-specific probability to invest for the statutory corporate tax rate in accordance with Buettner and Ruf (2007). However, Buettner and Wamser (2008) consider several non-profit taxes, which mostly do not show significant effects.

Table 5: Empirical studies applying discrete choice models on micro data

\begin{tabular}{|c|c|c|c|c|c|}
\hline Study & Data & Notes & Tax & Method & Main results \\
\hline Bartik (1985) & $\begin{array}{l}\text { Data on plant births in } \\
\text { US states, } 1972+ \\
1978\end{array}$ & Numerous controls & STR & Cond. Logit & $\begin{array}{l}\text { There is a significant negative effect of } \\
\text { state taxes on business location. }\end{array}$ \\
\hline $\begin{array}{l}\text { Devereux and Grif- } \\
\text { fith (1998) }\end{array}$ & $\begin{array}{l}\text { Microdata on US } \\
\text { multinationals' activi- } \\
\text { ties in F, GER, UK, } \\
1980-1994\end{array}$ & $\begin{array}{l}\text { Focus on relevance } \\
\text { of inframarginal vs. } \\
\text { marginal effective } \\
\text { tax burden }\end{array}$ & FL, BL & $\begin{array}{l}\text { Cond. Logit, } \\
\text { country and time } \\
\text { fixed effects }\end{array}$ & $\begin{array}{l}\text { Results show that the EATR as op- } \\
\text { posed to the EMTR plays a significant } \\
\text { deterring role in location decisions. }\end{array}$ \\
\hline Swenson (2001) & $\begin{array}{l}\text { Microdata on foreign } \\
\text { multinationals' activi- } \\
\text { ties in US states, } 1984 \\
-1994\end{array}$ & $\begin{array}{l}\text { Different transac- } \\
\text { tion types, credit vs. } \\
\text { exemption countries }\end{array}$ & STR & $\begin{array}{l}\text { Cond. Logit, } \\
\text { state fixed effects }\end{array}$ & $\begin{array}{l}\text { The tax-sensitivity of FDI differs } \\
\text { according to transaction type. M\&A } \\
\text { are positively correlated with host } \\
\text { country taxes. }\end{array}$ \\
\hline $\begin{array}{l}\text { Mutti and Grubert } \\
(2004)\end{array}$ & $\begin{array}{l}\text { Microdata on US } \\
\text { multinationals' activi- } \\
\text { ties in } 60 \text { locations, } \\
1996\end{array}$ & $\begin{array}{l}\text { Parent characteris- } \\
\text { tics, different indus- } \\
\text { tries }\end{array}$ & BL & $\begin{array}{l}\text { Random Effects } \\
\text { Probit }\end{array}$ & $\begin{array}{l}\text { Industries with above-average export- } \\
\text { orientation are more sensitive to host } \\
\text { country taxation. }\end{array}$ \\
\hline $\begin{array}{l}\text { Buettner and Ruf } \\
(2007)\end{array}$ & $\begin{array}{l}\text { Microdata on German } \\
\text { multinationals' activi- } \\
\text { ties in } 18 \text { OECD coun- } \\
\text { tries, } 1996-2003 \\
\text { (MiDi) }\end{array}$ & $\begin{array}{l}\text { Unobserved firm- } \\
\text { specific location } \\
\text { effects }\end{array}$ & FL, STR & $\begin{array}{l}\text { Fixed Effects } \\
\text { Logit, fixed firm- } \\
\text { country and time } \\
\text { effects }\end{array}$ & $\begin{array}{l}\text { Results of Devereux and Griffith } \\
\text { (1998) are generally confirmed. How- } \\
\text { ever, the statutory tax rate shows } \\
\text { stronger adverse effects as the only } \\
\text { weakly significant EATR. }\end{array}$ \\
\hline $\begin{array}{l}\text { Buettner and Wamser } \\
(2008)\end{array}$ & $\begin{array}{l}\text { Microdata on German } \\
\text { multinationals' activi- } \\
\text { ties in } 22 \text { OECD coun- } \\
\text { tries, } 1996-2004 \\
\text { (MiDi) }\end{array}$ & $\begin{array}{l}\text { Following Buettner } \\
\text { and Ruf (2007), } \\
\text { focus on non-profit } \\
\text { taxes }\end{array}$ & $\begin{array}{l}\text { BL, FL, } \\
\text { STR }\end{array}$ & $\begin{array}{l}\text { Fixed Effects } \\
\text { Logit, fixed firm- } \\
\text { country and time } \\
\text { effects }\end{array}$ & $\begin{array}{l}\text { There are robust negative effects on the } \\
\text { parent-specific probability to invest for } \\
\text { the statutory corporate tax rate. }\end{array}$ \\
\hline
\end{tabular}

Tax measures: Backward looking tax measures (BL), Forward looking tax measures (FL), Statutory tax rates (STR) Source: Own Compilation.

\subsubsection{Continuous Capital Data: Scale of Investment Conditional on Location Choice}

Desai et al. (2004) study the continuous investment decision conditional on locating in a certain country by means of firm-level data (see Table 6). They do not only consider corporate 
income taxes but additionally include local indirect taxes into their analysis. Based on BEA micro-data on US outbound activities in 1982, 1989 and 1994 they find a tax elasticity of foreign affiliate assets of about 7 for both indirect as well as income taxes. Overesch and Wamser (2008a) examine whether tax effects influence the decision on the scale of investment, i.e. they do not confine their analysis to discrete location choices as already described above. They show that tax effects are robust and highly significant based on their set of firm-level data (MiDi) that covers German investments in Eastern Europe and relies on a dynamic framework with differenced GMM estimation. This result holds independent from the use of statutory taxes or forward-looking tax measures (EATR and EMTR). Buettner and Wamser (2008) analyze the subsequent stages of the transnational investment decision separately. As regards the continuous investment decision - based on a dynamic specification - they report significant effects of their forward-looking tax burden measure which represents the tax wedge that was introduced by corporate taxation as part of the user cost of capital. Indirect taxes, which are additionally employed as regressors, do not reveal significant effects when the study controls for country fixed effects.

Table 6: Empirical micro data studies analyzing continuous investment decisions

\begin{tabular}{|c|c|c|c|c|c|}
\hline Study & Data & Notes & Tax & Method & Main results \\
\hline Desai et al. (2004) & $\begin{array}{l}\text { Micro-data on US multi- } \\
\text { nationals' outbound } \\
\text { activities, } \\
\text { 1982+1989+1994 (BEA) }\end{array}$ & $\begin{array}{l}\text { Additional focus on } \\
\text { indirect taxes }\end{array}$ & BL & $\begin{array}{l}\text { Fixed effects: OLS, } \\
\text { parent and industry } \\
\text { fixed effects }\end{array}$ & $\begin{array}{l}\text { Tax elasticity ranges around } 7 \\
\text { for corporate income as well } \\
\text { as indirect taxes. }\end{array}$ \\
\hline $\begin{array}{l}\text { Overesch and Wams- } \\
\text { er ( } 2008 \mathrm{a})\end{array}$ & $\begin{array}{l}\text { Micro-data on German } \\
\text { multinationals' activities } \\
\text { in EU 8,1996-2005 } \\
\text { (MiDi) }\end{array}$ & $\begin{array}{l}\text { Inter alia controlling } \\
\text { for infrastructure }\end{array}$ & FL, STR & $\begin{array}{l}\text { Fixed Effects: } \\
\text { GMM, time dum- } \\
\text { mies }\end{array}$ & $\begin{array}{l}\text { Tax effects are robust and } \\
\text { highly significant. }\end{array}$ \\
\hline $\begin{array}{l}\text { Buettner and Wamser } \\
(2008)\end{array}$ & $\begin{array}{l}\text { Micro-data on German } \\
\text { multinationals' activities } \\
\text { in } 22 \text { OECD countries, } \\
1996 \text { - } 2004 \text { (MiDi) }\end{array}$ & $\begin{array}{l}\text { Following Buettner } \\
\text { and Ruf (2007), focus } \\
\text { on non-profit taxes }\end{array}$ & $\begin{array}{l}\text { BL, FL, } \\
\text { STR }\end{array}$ & $\begin{array}{l}\text { Fixed Effects: OLS, } \\
\text { IV, with parent, } \\
\text { industry and country } \\
\text { dummies, GMM, } \\
\text { always time dum- } \\
\text { mies }\end{array}$ & $\begin{array}{l}\text { Continuous investment deci- } \\
\text { sions are influenced by the tax } \\
\text { wedge. Indirect taxes do not } \\
\text { matter as soon as country fixed } \\
\text { effects are controlled for. }\end{array}$ \\
\hline
\end{tabular}

Tax measures: Backward looking tax measures (BL), Forward looking tax measures (FL), Statutory tax rates (STR) Source: Own Compilation.

\section{The Meta-Dataset}

\subsection{Studies Covered}

Our data set results from the combination of the 25 studies that are provided by De Mooij and Ederveen (2003) and 21 additional studies. ${ }^{8}$ Six of these 21 studies, which are new to our data set as compared to De Mooij and Ederveen (2003), have already been included in De Mooij and Ederveen $(2005,2006)$, but we collected the corresponding information ourselves. Since we exclude an earlier version of Bénassy-Quéré et al. (2005) from the old data set taken from

8. Many thanks again to Ruud de Mooij for providing his data to us. 
De Mooij and Ederveen (2003), we finally obtain a sample of 45 studies of which 15 (33\%) have never been meta-analyzed before. ${ }^{9}$ Thus, all studies, which appeared in our review of the empirical evidence in Section 2, are covered by our data sample.

\subsection{New Variables}

In addition to the inclusion of new studies we added some new study or model characteristics to the original data set assembled by De Mooij and Ederveen (2003) which have not been coded before. In particular, we tried to capture model specifications in more detail. We therefore coded two dummies which respectively take a value of one if primary studies controlled for country or time fixed effects and zero otherwise. As regards tax measures employed in primary work, we now distinguish whether effective average or marginal tax rates reflect only host country provisions or also enclose bilateral tax agreements. For the latter case we code two new variables named bilateral effective average tax rate (BEATR) and bilateral effective marginal tax rate (BEMTR). In addition, we also introduce dummy variables adopting a value of one if the primary model controlled for some measure of public spending relevant from an investors' point of view (such as public inputs, public investment, infrastructure or education). Likewise, agglomeration effects are captured. Finally, we more closely describe the properties of the data by introducing dummies for studies that are based on aggregate data, aggregate data on affiliates or firm-level data, respectively. Another modification as compared to the old dataset concerns the classification of studies according to the properties of the data. We classify each study as either being based on time series, cross-section or panel data and consider the question whether discrete location choice has been examined as constituting a separate dimension of the literature. In particular this implies a deviation from the methodology chosen by De Mooij and Ederveen $(2005,2006)$ who treat studies that analyze discrete location choice as an alternative to time series, cross-section or panel data studies. As a result, we are able to precisely capture the different dimension of the primary literature as outlined in Section 2 within the scope of our meta-analysis.

\subsection{Meta-Samples}

We employ two different measures of primary effect size estimates. On the one hand, we rely on semi-elasticities, which are computed on the basis of the original primary estimates. The transformation of original estimates into comparable semi-elasticities (evaluated at the sample means) is already done by De Mooij and Ederveen (2003) for the observations included in

9. The excluded study is Bénassy-Quéré et al. (2001). 
their meta-study. Whenever necessary, we apply this procedure to those studies which have been newly adopted for our meta-analysis. ${ }^{10}$ For some studies or models, however, no semielasticities could be calculated. In particular, this holds for Buettner and Ruf (2007) as well as some models in Buettner and Wamser (2008). In these cases fixed effects logit estimation is applied which does not allow for the computation of the marginal effects needed to derive the tax semi-elasticities of foreign investment decisions. In addition to semi-elasticities, we also will employ primary t- and z-values as dependent variable in the meta-analysis. As is commonly known, t- and z-values result from the scaling of primary coefficients by their respective standard errors. ${ }^{11}$ They thus are by definition standardized and defined on a dimensionless scale. Consequently, they are comparable across different studies and models. However, some primary models include non-linearities with respect to the relationship between FDI and taxes. In these cases no exact standard errors of the total marginal effect can be calculated without information on the corresponding covariances. Following De Mooij and Ederveen (2003) we therefore resort to the assumption of zero covariances. ${ }^{12}$ As we also include z-values obtained from fixed effects Logit estimates in Buettner and Ruf (2007) and Buettner and Wamser (2008), the $t / z$-value meta-sample will include slightly more observations as compared to the sample for the analysis based on semi-elasticities. Furthermore, note that we exclude observations from both samples if the value of the semi-elasticity does not lie within a range of twice the standard deviation from the mean semi-elasticity of the study. Also note that in analogy to De Mooij and Ederveen (2003, 2005, 2006) we premultiply each semielasticity and each t-value by (-1). Thus, the higher one of these effect size measures, the higher is the implied adverse tax effect.

\section{Some Descriptive Statistics}

As Table 7 shows, the meta-dataset contains 730 observations in total. $35.1 \%$ of these observations are obtained from panel analyses on aggregate continuous capital data. Around $24 \%$ of the observations are taken from micro data studies (study classes 1, 2 and 3). Studies using aggregate data on affiliates (incl. count data) make up around $18 \%$ of the observations used in the meta-analysis. Time series studies mainly published in the 1980 s still make up $13 \%$ of the meta-dataset. The ratio of published work is generally high within the different study catego-

10. Many primary models, i.e. linear models with a log-level specification, directly produce point estimates of semi-elasticities. Hence no transformation is necessary.

11. For convenience we will only refer to "t-values" instead of " $t$ - and $z$-values" subsequently.

12. An alternative procedure would be to exclude the respective observations from the data sample underlying our t- and z-value based analysis. However, this would imply that the analysis based on semi-elasticities and the analysis based on the t-and z-values would rely on different data samples. This again would significantly reduce their comparability. 
ries. However, especially count data models exhibit until today a rather low publication ratio. This is explained by the relatively recent accomplishment of some of this research.

Table 7: Descriptive statistics

\begin{tabular}{|c|c|c|c|c|c|c|c|c|c|c|c|c|c|c|}
\hline \multirow{3}{*}{$\begin{array}{r}\text { Study } \\
\text { Class } \\
\\
1\end{array}$} & \multirow{2}{*}{\multicolumn{2}{|c|}{$\begin{array}{c}\text { Observations } \\
\text { (abs./ \%) }\end{array}$}} & \multicolumn{2}{|c|}{$\begin{array}{c}\text { Semi- } \\
\text { elasticities }\end{array}$} & \multicolumn{2}{|c|}{ T-Values } & \multirow{2}{*}{\multicolumn{2}{|c|}{$\begin{array}{c}\text { Published } \\
\text { (abs./\%) }\end{array}$}} & \multicolumn{6}{|c|}{$\begin{array}{l}\text { Tax type } \\
\text { (abs./\%) }\end{array}$} \\
\hline & & & mean & sd. & mean & sd. & & & & iward & & vard & & utory \\
\hline & 12 & $1.6 \%$ & 0.2 & 0.8 & 5.0 & 3.9 & 12 & $100.0 \%$ & 12 & $100.0 \%$ & 0 & $0.0 \%$ & 0 & $0.0 \%$ \\
\hline 2 & 40 & $5.5 \%$ & 1.0 & 0.5 & 3.7 & 2.2 & 31 & $77.5 \%$ & 3 & $7.5 \%$ & 33 & $82.5 \%$ & 4 & $10.0 \%$ \\
\hline 3 & 122 & $16.7 \%$ & $2.0^{*}$ & $5.0 *$ & 1.1 & 2.1 & 122 & $100.0 \%$ & 2 & $1.6 \%$ & 19 & $15.6 \%$ & 101 & $82.8 \%$ \\
\hline 4 & 73 & $10.0 \%$ & 6.0 & 4.8 & 2.7 & 1.0 & 73 & $100.0 \%$ & 39 & $53.4 \%$ & 0 & $0.0 \%$ & 34 & $46.6 \%$ \\
\hline 5 & 12 & $1.6 \%$ & 4.2 & 3.5 & 1.7 & 1.4 & 12 & $100.0 \%$ & 1 & $8.3 \%$ & 0 & $0.0 \%$ & 11 & $91.7 \%$ \\
\hline 6 & 21 & $2.9 \%$ & 1.2 & 4.6 & 0.9 & 1.4 & 14 & $66.7 \%$ & 0 & $0.0 \%$ & 6 & $28.6 \%$ & 15 & $71.4 \%$ \\
\hline 7 & 95 & $13.0 \%$ & 2.2 & 2.6 & 1.8 & 1.4 & 15 & $15.8 \%$ & 11 & $11.6 \%$ & 50 & $52.6 \%$ & 34 & $35.8 \%$ \\
\hline 8 & 95 & $13.0 \%$ & 2.5 & 4.4 & 1.5 & 2.2 & 95 & $100.0 \%$ & 48 & $50.5 \%$ & 47 & $49.5 \%$ & 0 & $0.0 \%$ \\
\hline 9 & 4 & $0.5 \%$ & 5.7 & 6.2 & 1.4 & 1.5 & 4 & $100.0 \%$ & 0 & $0.0 \%$ & 0 & $0.0 \%$ & 4 & $100.0 \%$ \\
\hline 10 & 256 & $35.1 \%$ & 2.9 & 3.2 & 3.3 & 3.9 & 131 & $51.2 \%$ & 54 & $21.1 \%$ & 139 & $54.3 \%$ & 63 & $24.6 \%$ \\
\hline All & 730 & $100.0 \%$ & 2.8 & 3.9 & 2.4 & 3.0 & 498 & $68.2 \%$ & 170 & $23.3 \%$ & 294 & $40.3 \%$ & 266 & $36.4 \%$ \\
\hline
\end{tabular}

Study Class: 1 - cross-section/micro/location choice; 2 - panel/micro/cont. capital; 3 - panel/micro/location choice; 4 - crosssection/aggregate affiliate/cont. capital; 5 - cross-section/aggregate affiliate/location choice; 6 - panel/aggregate affiliate/cont. capital; 7 panel/aggregate affiliate/location choice; 8 - time series/aggregate/cont. capital; 9 - cross-section/aggregate/cont. capital; 10 - panel/aggregate/cont. capital.

Abbreviations: sd.: Standard deviation. abs. : absolute numbers. Backward: Backward-looking tax rates. Forward: Forward-looking tax rates. Statutory: Statutory Tax Rates.

Strikingly, micro data studies show on average relatively low semi-elasticities while the mean t-values are high as compared to studies based on aggregate data. Interestingly, each type of tax burden measure - backward-looking, forward-looking or statutory tax rates - is applied in nearly all study classes. There are, however, some exceptions. For example, forward-looking tax rates are not at all applied in cross-sectional studies based on aggregate data on affiliates which are actually dominated by US literature. In return, forward-looking tax rates make up the highest share of models in panel studies based on firm-level continuous capital data.

\section{A Full-Scale Meta-Study}

\subsection{The Methodological Framework of Meta-Analytic Estimators}

Sophisticated meta-studies may resort to a broad range of meta-analytical techniques to assess heterogeneous empirical evidence on a certain question of interest. These techniques, however, should not be considered in isolation from each other. Quite the contrary, if thoroughly applied all meta-analytical tools combine to form a consistent methodological framework which systematically exploits the heterogeneity of primary evidence. Meta-analytical eco- 
nomic research explicitly focusing on conceptual issues and therefore choosing a rather technical approach to the methodology has multiplied during recent years. Instructive examples are e.g. Stanley (2005, 2008), Brons, Nijkamp, Pels and Rietveld (2008) and in particular Brons (2006) and Bom and Ligthart (2008). ${ }^{13}$ We follow these convincing approaches. Moreover, we present the full set of meta-analytical estimators in a formally integrated framework. This framework then forms the basis of our meta-analytical estimation strategy.

\subsubsection{Classical Meta-Analysis}

In an initial step, meta-analytical techniques are used to combine single study results to an overall estimate which subsequently can be tested for significance. One possible way to directly uncover the overall statistical significance of the relationship between host country corporate taxation and foreign direct investment would be to perform Fisher's combined test on p-values of the individual estimates. However, this test suffers from several shortcomings. In particular it does not indicate the sign of the effect that was tested for significance (Jarrell and Stanley 2004). Therefore we concentrate on the computation of pooled effect estimates via the use of fixed or random effects meta-analysis.

Conceptually, both fixed and random effects meta-analysis estimates result from weighted least squares (WLS) regression of individual coefficient sizes on an intercept only, where the inverse of the effect size variance is used as analytical weight. ${ }^{14}$ The fixed effects metaanalysis builds on the rather strong assumption that all considered studies generally estimate the same true underlying effect. Any deviation of the single effect estimate from this true effect is thus explained by pure sampling error.

Let $\hat{\gamma}_{i}$ be the study-specific estimate of the true effect $\gamma_{i}$ underlying the primary studies $i=1, \ldots, N$. If the true effect is supposed to be the same for all primary studies $i=1, \ldots, N$ such that $\gamma_{i}=\gamma_{0}$, we can write the model underlying FE meta-analysis as

$$
\hat{\gamma}_{i}=\gamma_{0}+\varepsilon_{i}
$$

$\varepsilon_{i}$ represents the error term satisfying $E\left(\varepsilon_{i}\right)=E\left(\varepsilon_{i} \mid \gamma_{i}\right)=0$, and $\sigma_{\varepsilon_{i}}^{2}=V\left(\varepsilon_{i}\right)=V\left(\hat{\gamma}_{i} \mid \gamma_{i}\right)$. The fixed effects pooled estimator, i.e. the WLS estimator $\bar{\gamma}$ of $\gamma_{0}$, is given by

13. The very foundations of meta-analysis, also in a technical sense, have meanwhile been laid by inter alia Hedges and Olkin (1985), Hunter and Schmidt (1990), Stanley and Jarrell (1989, 1998), Jarrell and Stanley (1990) and Stanley (1998, 2000a, b).

14. Therefore, they should not be confused with the homonymous panel econometric approaches. 


$$
\bar{\gamma}=\frac{\sum_{i=1}^{N} w_{i} \hat{\gamma}_{i}}{\sum_{i=1}^{N} w_{i}}
$$

As $\hat{\gamma}_{i}$ is regressed on a constant only, the (efficient) WLS analytic weights are just the reciprocal unconditional variances of $\hat{\gamma}_{i}$. Since $\gamma_{i}=\gamma_{0}$ is assumed, the unconditional observation variance equals the variance conditional on $\gamma_{i}$, i.e. $V\left(\hat{\gamma}_{i}\right)=V\left(\hat{\gamma}_{i} \mid \gamma_{i}\right)=\sigma_{\varepsilon_{i}}^{2}$. The WLS analytical weights thus simplify to $w_{i}=1 / V\left(\hat{\gamma}_{i}\right)=1 / \sigma_{\varepsilon_{i}}^{2}$. By definition $V\left(\hat{\gamma}_{i} \mid \gamma_{i}\right)$ - or better: its consistent estimate - is generally derived from the estimated variances matrices of the primary regressions. Thus, the variance of the idiosyncratic error $\sigma_{\varepsilon_{i}}^{2}$ is assumed as known.

In contrast to fixed effects meta-analysis, random effects meta-analysis explicitly allows for a distribution of primary effect size estimates beyond pure sampling error, assuming that the underlying true effect sizes randomly differ from study to study.

Let $\hat{\gamma}_{i}$ again be the estimate of the true effect $\gamma_{i}$ for studies $i=1, \ldots, N$ and let $\varepsilon_{i}$ again be the error with the same (conditional) moments as defined above. By assumption, $\gamma_{i}$ is drawn from a random distribution such that $\gamma_{i}=\gamma_{0}+\mu_{i}$ with $\mu_{i} \sim i i d\left(0, \sigma_{\mu}^{2}\right)$. Hence, we can write

$$
\hat{\gamma}_{i}=\gamma_{0}+\mu_{i}+\varepsilon_{i}
$$

Again the pooled estimator is described by formula (2). However, the (efficient) weights $w_{i}=1 / V\left(\hat{\gamma}_{i}\right)$ applied to calculate $\bar{\gamma}$ differ in that they now take account of an additive variance component $\sigma_{\mu}^{2}$. While $\sigma_{\mu}^{2}$ represents the between-study variance, $\sigma_{\varepsilon_{i}}^{2}$ is consistently referred to as the within-variance. The resulting precision weights in the case of random effects meta-analysis are then given by $w_{i}=1 / V\left(\hat{\gamma}_{i}\right)=1 /\left(\sigma_{\mu}^{2}+\sigma_{\varepsilon_{i}}^{2}\right) \cdot \sigma_{\varepsilon_{i}}^{2}$ is again derived from the primary estimates. Instead, $\sigma_{\mu}^{2}$ has to be estimated in a first step. ${ }^{15}$

Since the underlying assumptions of fixed and random effects meta-analysis are mutually exclusive, there is a need to test for their respective validity in order to finally choose the adequate estimator for the data at hand. A common test for the null hypothesis of between-study 
homogeneity, i.e. a between-study variance $\sigma_{\mu}^{2}$ of zero, is the Q-test. It is based on the $\chi^{2}$ distributed Q-statistic given by

$$
\mathrm{Q}=\sum_{\mathrm{i}=1}^{\mathrm{L}} w_{i} \hat{\gamma}_{i}^{2}-\frac{\left(\sum_{i=1}^{L} w_{i} \hat{\gamma}_{i}\right)^{2}}{\sum_{i=1}^{L} w_{i}} \sim \chi^{2}(\mathrm{~L}-1),
$$

with all variables as defined above and $w_{i}$ as the fixed effects weights.

As soon as the computed Q-statistic forces to reject the null of between-study homogeneity, the simple fixed effects meta-analysis is no longer applicable. However, even classical random effects meta-analysis remains limited in scope. It in fact takes account of the existing heterogeneity beyond sampling error, but it does not attempt to systematically explain this excess variability of primary effect size estimates.

\subsubsection{Meta-Regression}

Consequently, most modern meta-studies turn to meta-regression and thus go beyond classical meta-analysis based on "empty models" by introducing relevant explanatory variables. Since these meta-regression models imply a conceptual extension of classical random effects meta-analyses, the underlying econometric models remain relatively straightforward. However, the notation chosen hereafter will take account of the fact that many meta-studies follow the suggestions by Bijmolt and Pieters (2001) to use the information from all estimated models in primary studies for meta-regressions (so-called multiple sampling). ${ }^{16}$

Depending on whether all the heterogeneity beyond sampling error can be systematically captured by the moderator variables, meta-regression analysis can be classified into fixed effects versus mixed (also called random) effects meta-regression.

The fixed effects meta-regression model is given by

$$
\begin{aligned}
& \hat{\gamma}_{i s}=\gamma_{i s}+\varepsilon_{i s} \\
& \gamma_{i s}=\gamma_{0}+\mathbf{x}_{\mathbf{i}} \boldsymbol{\beta}+\mathbf{z}_{\text {is }} \boldsymbol{\delta},
\end{aligned}
$$

where $\hat{\gamma}_{i s}$ represents the $s^{\text {th }}$ effect size estimate sampled from study $i . \gamma_{0}$ is the intercept and $\mathbf{x}_{i}$ and $\mathbf{z}_{i s}$ are vectors with study-specific and model-specific variables respectively. $\varepsilon_{i s}$ is the

16. Multiple sampling leads to more powerful tests and more accurate estimates due to the larger underlying sample as compared to single estimate sampling. Multiple sampling is applied inter alia in Feld, Baskaran and Schnellenbach (2007) or De Mooij and Ederveen (2003, 2005, 2006). The question whether single estimate or multiple sampling should be applied, however, is not beyond controversy (see e.g. Stanley 2001). 
error term satisfying $E\left(\varepsilon_{i s}\right)=E\left(\varepsilon_{i s} \mid \gamma_{i s}\right)=0 . \quad$ We further define $\sigma_{\varepsilon_{\text {is }}}^{2}=V\left(\varepsilon_{i s} \mid \mathbf{x}_{\mathbf{i}}, \mathbf{z}_{\text {is }}\right)=V\left(\hat{\gamma}_{\text {is }} \mid \gamma_{\text {is }}\right)$.

Correspondingly, the mixed effects meta-regression can be written as

$$
\begin{aligned}
& \hat{\gamma}_{i s}=\gamma_{i s}+\varepsilon_{i s} \\
& \gamma_{i s}=\gamma_{0}+\mathbf{x}_{\mathbf{i}} \boldsymbol{\beta}+\mathbf{z}_{\text {is }} \boldsymbol{\delta}+\mu_{i s}
\end{aligned}
$$

Obviously some systematically unexplained heterogeneity $\mu_{i s} \sim \operatorname{iid}\left(0, \sigma_{\mu}^{2}\right)$ remains. All other variables are as defined in (5).

In traditional meta-studies both fixed effects and mixed effects meta-regression models are estimated by WLS. Generally, the employed analytical weights $w_{i s}$ correspond to the reciprocal conditional effect size variance implying $w_{i s}=1 / V\left(\hat{\gamma}_{i s} \mid \mathbf{x}_{\mathbf{i}}, \mathbf{z}_{\text {is }}\right)$. In the case of WLS within a fixed effects meta-analytic framework it holds that $\sigma_{\varepsilon_{\text {is }}}^{2}=V\left(\hat{\gamma}_{i s} \mid \mathbf{x}_{\mathbf{i}}, \mathbf{z}_{\text {is }}\right)=V\left(\hat{\gamma}_{\text {is }} \mid \gamma_{\text {is }}\right)$. Remember that we can derive $V\left(\hat{\gamma}_{i s} \mid \gamma_{i s}\right)$ - or more precisely: the consistent estimate $\hat{V}\left(\hat{\gamma}_{i s} \mid \gamma_{\text {is }}\right)$ - from the primary models. Furthermore, if WLS is applied to estimate a mixed effects meta-regression model, $V\left(\hat{\gamma}_{\text {is }} \mid \mathbf{x}_{\mathbf{i}}, \mathbf{z}_{\text {is }}\right)$ again contains an additive component representing the between-variance. It holds that $V\left(\hat{\gamma}_{i s} \mid \mathbf{x}_{\mathbf{i}}, \mathbf{z}_{\text {is }}\right)=\sigma_{\mu}^{2}+\sigma_{\varepsilon_{\text {is }}}^{2} \cdot{ }^{17}$ As in classical random effects meta-analysis, $\sigma_{\mu}^{2}$ must again be estimated. Instead, $\sigma_{\varepsilon_{\text {is }}}^{2}$ still is considered as known.

Particularly for mixed effects meta-regression models, however, estimators other than WLS might be considered. Precisely, pooled OLS (POLS) as well as feasible GLS (FGLS) estimation techniques are applicable. While POLS treats each observation equally without applying any weighting scheme, FGLS again implies a weighting of observations. However, in contrast to the WLS estimation the weighting matrix is not supposed to be (partly) known. It is rather fully estimated on the basis of POLS residuals. POLS or FGLS might be favored by metaanalysts if the unobserved heterogeneity beyond sampling error is perceived as a dominant driver of the meta-regression disturbance. The disturbance in this case is simply $v_{i s}=\mu_{i s}+\varepsilon_{i s}$,

17. We have $V\left(\hat{\gamma}_{i s} \mid \mathbf{x}_{\mathrm{i}}, \mathbf{z}_{\mathrm{is}}\right)=V\left(\mu_{\mathrm{is}} \mid \mathbf{x}_{\mathrm{i}}, \mathbf{z}_{\mathrm{is}}\right)+\sigma_{\varepsilon_{\mathrm{is}}}^{2}$. The between-variance by definition is constant across observations so that $V\left(\mu_{i s} \mid \mathbf{x}_{\mathrm{i}}, \mathbf{z}_{\text {is }}\right)=\sigma_{\mu}^{2}$. 
but without explicit decomposition into sampling error $\varepsilon_{i s}$ and heterogeneity beyond sampling error $\mu_{i s} . v_{i s}$ must be assumed as iid-distributed with all classical moment conditions for linear regression models. As regards the fixed effects meta-regression model, it by definition should be estimated via WLS since $\sigma_{\varepsilon_{i s}}^{2}$ can be derived from the primary literature, i.e. the applicable weights are very reliably known.

Apparently, all the different estimators explained so far basically differ in their applied weighting schemes. The best choice among them should thus primarily be guided by efficiency concerns. None of them, however, explicitly takes account of the cluster-sample characteristics of the meta-dataset and the implied possibility of dependence of observations. Taking these issues into account, not only efficiency is at stake, but - under certain conditions - even consistency. However, if model (6) is transformed such that it shows a nested error structure, it can be estimated with cluster-econometric estimation techniques that control for the unobserved study-level heterogeneity. The meta-analytical literature in this case often refers to hierarchical or multilevel models. As opposed to the fixed and mixed effects meta-regressions, these multilevel models account for non-zero off-diagonal elements of the variancecovariance-matrix, e.g. for within-study correlation resulting from the unobserved studyspecific effects. Basically, these multilevel models correspond to random effects models in cluster-econometric terms ${ }^{18}$ and as such can be written as

$$
\begin{aligned}
& \hat{\gamma}_{i s}=\gamma_{i s}+\varepsilon_{i s} \\
& \gamma_{i s}=\gamma_{0}+\mathbf{x}_{\mathrm{i}} \boldsymbol{\beta}+\mathbf{z}_{\text {is }} \boldsymbol{\delta}+\mu_{i}
\end{aligned}
$$

with $\mu_{i} \sim$ iid $\left(0, \sigma_{\mu}^{2}\right)$ being the unobserved heterogeneity at the study-level.

However, random effects models (in cluster-econometric terms) should be considered with caution. Not only should one test for the mere existence of an unobserved study-level effect, but equally important is a test whether the nested error and the meta-regressors are uncorrelated. Surprisingly, neither test is routinely performed in multilevel meta-analyses. Instead, the absence of an endogeneity problem is simply imposed by assumption. If, however, unobserved study-level heterogeneity exists and it is correlated with the meta-regressors, multilevel meta-analysis (as well as pooled estimators) will not be consistent. In this case only a fixed effects cluster-econometric approach is viable.

18. Rather basic multilevel models are also referred to as random intercept models. In principle, they might be extended to more complex forms known as random coefficient models (see e.g. Goldstein 1995). Also more than two levels might be considered. Econometrically this affects the definition of the nested error terms. 


\subsection{Publication Bias}

So far we focused on the methodological framework integrating all meta-analytical estimators. However, another important issue in the meta-analytical literature is the identification and remedy of publication bias. ${ }^{19}$ It is presumed that authors or referees of primary literature might - even unconsciously - prefer statistically significant results over the reporting of insignificant effects in published work. Authors might adjust their model specifications, employed estimators or data samples until significance is eventually found. If this were indeed the case, particularly authors working on small-sample studies and therefore struggling with imprecise estimates would have to seek to produce large effect size estimates. In this line of reasoning, nearly all meta-analytical techniques designed to identify publication bias draw on the correlation of primary effect size estimates and their respective standard errors.

Consequently, most statistical instruments for the detection of publication bias imply the introduction of the primary effect measures' standard error as a moderator variable into the meta-analytical regression equations. A significant partial effect of the primary standard error on effect size then provides evidence for the existence of publication bias. From a methodological perspective, these tests for publication bias can extend classical meta-analysis as well as sophisticated meta-regressions which already control for the influence of other relevant study and model characteristics. Many of the statistical models coping with publication bias as e.g. presented in Stanley (2005) are, however, somewhat restricted. Precisely, they assume that the potential publication bias is only one-directional. Primary work then would not just seek significance, but the effect searched for is additionally supposed to exhibit a predetermined sign. More general models which instead allow for bi-directionality of publication bias mainly rely on the absolute primary effect size estimates as dependent variable. They therefore might indeed verify the significance of even bi-directional publication bias. They are, however, not able to simultaneously compute meaningful partial effects of model and study characteristics on the primary effect size estimates or - with respect to classical meta-analysis - a meaningful pooled effect size measure.

Only recently, Bom and Ligthart (2008) have developed a framework allowing for directionally unrestricted publication bias which does not rely on the absolute effect size estimates as dependent variable. Their suggested econometric solution works in a random as well as in a

19. For a concise methodological survey see Stanley (2005). Stanley has been pioneering meta-analysis in economics with a focus on publication bias (see also e.g. Stanley 2001, 2008). 
fixed effects meta-analytical context. It can by construction be applied to both classical metaanalysis as well as meta-regressions. We will, however, only focus on the meta-regression application of the procedure developed by Bom and Ligthart. ${ }^{20}$ This yields the following general meta-regression formula:

$$
\hat{\gamma}_{i s}=\gamma_{0}+\mathbf{x}_{\mathbf{i}} \boldsymbol{\beta}+\mathbf{z}_{\text {is }} \boldsymbol{\delta}+\varphi_{1} \operatorname{se}\left(\hat{\gamma}_{i s} \mid \gamma_{\text {is }}\right) D_{\text {pis }}+\varphi_{2} \operatorname{se}\left(\hat{\gamma}_{i s} \mid \gamma_{\text {is }}\right) D_{\text {nis }}+v_{\text {is }}
$$

All parameters and variables are defined as above. The scalars $\varphi_{1}$ and $\varphi_{2}$ measure the (possibly asymmetric) effect on $\hat{\gamma}_{\text {is }}$ exerted by primary model precision as measured by the primary estimate's standard error $s e\left(\hat{\gamma}_{i s} \mid \gamma_{\text {is }}\right)$. $D_{\text {pis }}\left(D_{\text {nis }}\right)$ are dummies equaling one if $\hat{\gamma}_{\text {is }}>0$ $\left(\hat{\gamma}_{i s}<0\right)$. These dummies actually allow for the bi-directionality of the bias. The disturbance term $v_{i s}$ contains the error components and thus differs according to whether meta-regression model (5), (6) or (7) is assumed.

Following the idea of publication bias, meta-regression models using primary t-values as dependent variable should not include primary standard errors as a regressor. In the logic of publication bias there is correlation between estimated effect size magnitude and precision because authors with the aim to publish are persistently seeking high t-values. Consequently, there should be no correlation between these t-values and the standard errors if publication bias was present. What is more, such a specification would imply a severe simultaneity problem. We will, however, control for the existence of publication bias via the inclusion of a dummy variable reflecting the publication status of primary work.

\section{Estimation Strategy}

\subsection{Classical Meta-Analysis and First-Stage Meta-Regressions}

Our estimation strategy will be based on a step-by-step procedure. First, a classical metaanalysis will be performed. It will produce information about the presumed existence of some heterogeneity beyond sampling error and the adequate pooled effect estimate. Subsequently, the focus will be on the full set of meta-regression estimators outlined above. These firststage meta-regressions will thereby include a very basic set of meta-regressors which accord-

20. Extending classical meta-analysis with respect to publication bias actually boils down to a regression on one moderator variable. The results of simple linear bivariate regressions, however, might be somewhat misleading as they do not necessarily correspond to multiple regressions on the full set of relevant variables. 
ing to the literature review in Section 2 are assumed to be most fundamental. Eventually, after identifying the underlying data characteristics by means of suitable tests we will be able to choose our preferred model. On the basis of this model which best fits the meta-data at hand we will estimate several extensions of the basic model focusing on different research questions. Subsequently, some further robustness checks will be performed.

As to the sequence of meta-regression estimators, the simplest but most fundamental firststage meta-regression will be the POLS estimate of model (6). Following Wooldridge (2002, 2003), standard errors robust to arbitrary heteroscedasticity and correlation within clusters will be calculated. The latter seems highly advisable in the case of POLS since it neglects the possible existence of study-specific unobserved effects as well as possible correlation in the idiosyncratic errors. In other words, we have to make POLS standard errors immune to the possibility that model (7) rather than (6) is the true model. Leaving existing unobserved effects not modeled would produce intra-cluster correlation and imply underestimated standard errors, thus leading to incorrect, i.e. anti-conservative, inference. Second, as regards correlation in the idiosyncratic errors, Wooldridge (2003) hints at possible intra-cluster correlation if common slopes across clusters (here: studies) are assumed.

According to the methodological system of meta-analytical estimators outlined above we will estimate model (5) with "traditional" WLS. Besides simple POLS, model (6) will also be estimated by WLS as it is regularly done in traditional meta-analysis. Moreover, model (6) will be estimated by FGLS, as well. By weighting with the inverse of the conditional variance matrix - either estimated from POLS residuals (FGLS) or taken from the primary studies (WLS) - these estimators are able to explicitly correct for the supposedly high degree of heteroscedasticity in the meta-regression disturbances. However, for the same reasons as in the case of POLS we will again compute standard errors clustered at the study-level for all estimators. Finally, the full set of meta-regression estimators will be completed with model (7) being estimated by random effects and the more robust fixed effects cluster-econometric techniques in order to take account of possible study-specific unobserved heterogeneity and the implied potential dependence problem. As regards random effects cluster-econometrics, the most popular estimator in the meta-analytical context is the restricted maximum likelihood estimator (REML). Besides REML we will also employ the standard GLS random effects estimator. $^{21}$

21. Both estimators are closely related as random GLS estimates can be obtained from ML estimation by restricting the number of iterations to one (Hox 2002). 
With respect to the fixed effects cluster-econometric techniques, we will employ the standard within-estimator. However, another interesting estimator for fixed effects analysis has been proposed by Pluemper and Troeger (2007). Their fixed effects vector decomposition estimator (FEVD) is able to cope with endogeneity problems and neither has to eliminate all variables which are invariant within clusters nor relies on instrumental variables as in the case of the more established Hausman-Taylor approach. As study-level variables are by definition constant within studies and instruments will hardly be available in the meta-analytical context, FEVD here might be an appealing alternative to the standard within-estimator. FEVD estimation is based on a three-step algorithm. In a first step, standard fixed effects estimates are computed. Estimated cluster-specific effects then are regressed on within-invariant clusterlevel variables. The previously generated cluster-specific effects are thus decomposed into an explained part - explained by the observed cluster-specific variables - and an unexplained part. Subsequently, only the unexplained part, i.e. the step 2 residuals, is again included into the original estimation equation. This equation, containing within-invariant, within-variant variables and the unexplained part of the cluster-specific effect, now can be estimated by POLS because the endogeneity problem has been resolved. ${ }^{22}$ However, as by construction the FEVD estimator yields the same coefficient as standard within-estimation for all withinvariant model characteristics we only regard it as an option for the second stage regressions.

Notably, these first-stage regressions will be run twice. In a first step the semi-elasticities will serve as the dependent variable and in a second step the t-values taken from the primary regressions will be used as the dependent variable. ${ }^{23}$ This is in line with our major aim to fully and transparently exploit all the information available from primary studies. The division by standard errors guarantees that t-values are defined on a common dimensionless scale that is independent of the original metric. Consequently, they are a valid methodological alternative to the use of semi-elasticities. Using t-values as effect-size index is also advocated by Jarrell and Stanley $(1989,2005)$. However, as has been underscored by Becker and $\mathrm{Wu}(2007)$, tvalues do not correspond to pure estimators of effect magnitude. In addition to effect magnitude, $t$-values are influenced by the precision of the estimate. They are thus estimators of effect significance rather than mere effect magnitude. Correspondingly, a positive partial corre-

22. The FEVD estimator has been applied in recent studies e.g. by Beckmann (2007) and Gatti (2008).

23. We will, however, not run WLS meta-regressions with t-values as the dependent variable. The use of tvalues as dependent variable can be interpreted as restricting the precision-weighting implied by WLS metaregression to only the left-hand side of model (5). There should thus be no difference between estimation of model (5) with POLS or WLS when t-values are used as dependent variable since the WLS analytical weights by definition are equal to one. Heteroscedasticity now might, however, result from additional error components, i.e. unexplained heterogeneity as in model (6). We will therefore also employ the most flexible pooled estimator applying a weighting scheme: FGLS. 
lation between t-values and a certain regressor would reveal that the respective study or model characteristic on average fosters the identification of significant adverse tax effects on FDI.

\subsection{Choosing the Preferred Meta-Regression Estimator}

From the first-stage meta-regressions for both dependent variables only the preferred estimators will form the basis for the subsequent general-to-specific analyses. Therefore we will after running a standard RESET test for misspecification - employ a set of suitable statistical tests to systematically guide this choice.

In meta-analyses the conditional variance of the idiosyncratic error $V\left(\varepsilon_{i s} \mid \mathbf{x}_{\mathbf{i}}, \mathbf{z}_{\text {is }}\right)$ is directly derived from the estimated variance matrix of the corresponding primary models. It is specific to each model and depends mainly on factors such as sample size and estimation method. Apparently, meta-analyses by construction have a problem with heteroscedasticity. The natural starting point of our sequence of statistical tests is thus a standard test for heteroscedasticity such as the White-test or the Breusch-Pagan test.

If the null of homoscedasticity is indeed rejected, this will in general favor estimation techniques such as WLS estimates of models (5) and (6) or FGLS due to their explicit treatment of the heteroscedasticity in the disturbances. ${ }^{24}$ Estimates of model (6) should be preferred over those of model (5) if the Q-test for heterogeneity still rejects its null even after introduction of the moderator variables. However, none of these pooled estimators would be efficient - and under certain conditions not even be consistent - in the case of observation dependence due to unobserved study-level heterogeneity.

We therefore explicitly test for presence of unobserved cluster effects. However, we do not solely argue based on the results of a standard Breusch-Pagan LM test. Instead, we in addition adapt a similar test proposed by Wooldridge (2002) to the meta-analytic unbalanced clustersample context. The test is robust to a non-normal distribution and - in particular - heteroscedasticity of the regression error terms. The test has power both against a random effects specification as well as against any kind of serial correlation in the errors. Offering these appealing features the test seems predestined for application in the meta-analytical context.

Since under the null of no within-cluster correlation the variance matrix of the disturbances for each study is diagonal, the Wooldridge-type test verifies if the average sum of the esti-

24. In order to estimate the weighting matrix supposed as unknown in FGLS we regress the squared POLS residuals (in logs) on the full set of meta-regressors and then exponentiate the fitted values. This fairly flexible procedure has already been proposed by Harvey (1976). For details see Greene (2003). 
mated non-diagonal elements across studies (scaled up by $\sqrt{N}$ ), $N^{-0,5} \sum_{i=1}^{N} \sum_{s=1}^{S_{i}-1} \sum_{r=s+1}^{S_{i}} v_{i s} v_{i r}$, is statistically different from zero. Therefore, we must scale it by its asymptotic standard error and finally get the test statistic

$$
\frac{\sum_{i=1}^{N} \sum_{s=1}^{S_{i}-1} \sum_{r=s+1}^{S_{i}} \hat{v}_{i s} \hat{v}_{i r}}{\left[\sum_{i=1}^{N}\left(\sum_{s=1}^{S_{i}-1} \sum_{r=s+1}^{S_{i}} \hat{v}_{i s} \hat{v}_{i r}\right)^{2}\right]^{0.5}}
$$

The subscript $i=1, \ldots, N$ denotes the studies included in the analysis, while $s=1, \ldots, S_{i}$ indexes the observed estimates per study. $\hat{v}_{i s}$ represents the pooled OLS residuals used as estimators for the pooled regression error $v_{i s}$. Under the null hypothesis this statistic is distributed asymptotically as standard normal. Not rejecting the null clearly advocates the use of pooled estimators. The test statistic's null distribution, however, is only asymptotically valid. With $N=44$ (semi-elasticities) or $N=45$ (t-values) respectively we are clearly at the lower bound of the sample size needed for reliable asymptotic inference. We are, however, convinced that the test might give us additional interesting insights.

In a further step, we check whether there is an endogeneity problem linked to the unobserved heterogeneity. If this is indeed the case, standard pooled or multilevel techniques will not yield consistent estimates. Instead, fixed effects cluster-econometric approaches must be employed. However, the Hausman test as a standard tool for endogeneity checks should not be applied in the meta-analytical context due to heteroscedasticity in the disturbances. Instead, we use the robust artificial regression approach proposed in Wooldridge (2002) which is equivalent to the Hausman test. The test is obtained by estimating an artificial regression of the following form

$$
\hat{\gamma}_{i s}=\widehat{\mathbf{w}}_{\text {is }} \boldsymbol{\alpha}+\ddot{\mathbf{z}}_{\text {is }} \varsigma+v_{\text {is }}
$$

where $\hat{\gamma}_{i s}$ is the quasi-demeaned version of $\gamma_{i s} . \widehat{\mathbf{w}}_{\text {is }}=\left(\widehat{\mathbf{x}}_{\mathbf{i}}, \widehat{\mathbf{z}}_{\text {is }}\right)$ represents a vector containing the quasi-demeaned study-level and model-level variables in $\mathbf{x}_{\mathbf{i}}$ and $\mathbf{z}_{\text {is }}$ respectively. $\ddot{\mathbf{z}}_{\text {is }}$ is the fully demeaned version of all elements of $\mathbf{z}_{\text {is }}$ which vary within studies. ${ }^{25} v_{\text {is }}$ is a homoscedastic and independent error term. The test rejects the null of no correlation between indi- 
vidual error component and independent variables if the set of coefficients in vector $\varsigma$ is statistically significant.

Figure 2: Meta-analytical instruments and estimation strategy

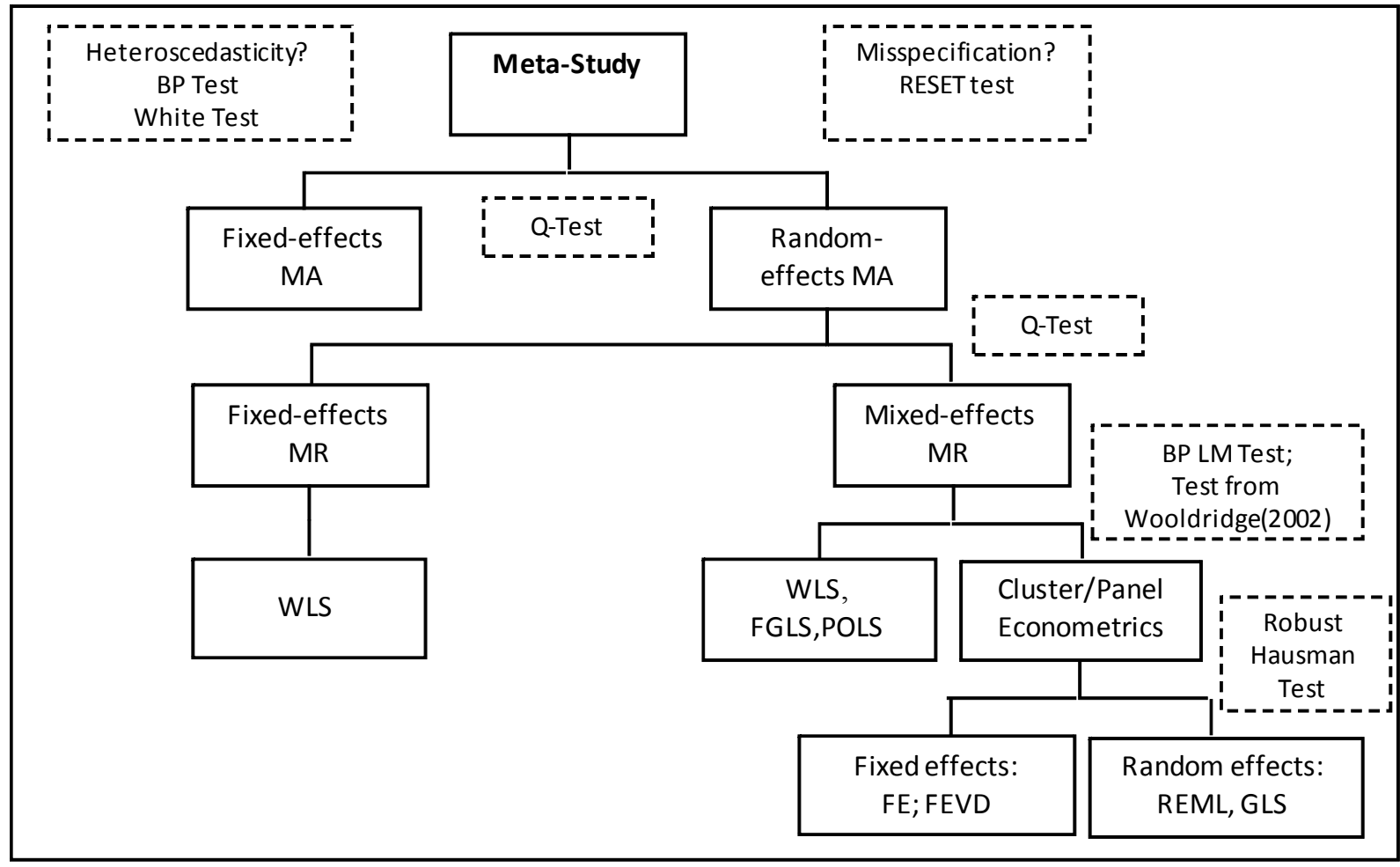

Figure 2 illustrates the meta-analytical set of estimators and their conceptual relationships. Also the tests applied to chose the most suitable among these estimators according to the meta-data at hand is reflected in Figure 2. It thus draws on the explanations given in Section 5.1 and Section 6.2.

\subsection{Expected Results}

The insights sought for in this meta-study on the effect of taxation on FDI are twofold. With the number of observations almost doubled it will be interesting to see whether the implications derived from primary empirical research today are the same as in the past. Due to the sophisticated estimation strategy the meta-results will be of outstanding precision. On the other hand, we will employ the meta-analysis to learn about the influence of the newly included meta-variables on the effect size estimates. With respect to the publication bias control we might expect this phenomenon to be present. Publication bias has been detected in almost all fields of empirical sciences and we do not expect FDI research to be an exemption.

As regards the more detailed differentiation of tax burden measures used in primary studies we follow the reasoning put forward by Egger et al. (2008) and suggest that bilateral forward- 
looking tax rates best capture the tax effect on transnational investments. Thus, we expect studies relying on these bilateral measures to yield the highest effect size estimates, resulting in a positive coefficient for the respective meta-regression dummy. As for the difference in tax effect size estimates between aggregate and micro data studies we follow the line of thought outlined in Becker et al. (2006) who argue that studies relying on aggregate FDI data might suffer from simultaneity and endogeneity problems. If large unobservable parts of the aggregate location conditions are not controlled for but put into the primary regression error, this might bias measured tax effects. We are, however, not exactly sure about the sign of this bias. In the same line of reasoning, controlling for country fixed effects in primary regression models might indeed alter the estimated tax effects. As they should correct for possible biases due to unobserved country effects, we expect the opposite sign as compared to the one found for the "aggregate"-dummies. However, taxes are part of a country's aggregate location characteristics and only limitedly time-variant. Consequently, their influence might be captured to a large extent by the country-specific effects. Controlling for the latter might thus reduce the significances of measured tax effects.

As to the inclusion of time dummies into primary regressions, its effects are more difficult to anticipate. Time fixed effects generally absorb the influence that temporary (unobserved) macroeconomic conditions exert on the considered dependent variable. However, if taxes do not sufficiently vary across cross-section units (firms within countries or countries within considered regions) within the different time periods, then time fixed effects might mitigate identified tax effects or - precisely - their significance.

As to the inclusion of expenditure side variables into primary models, we derive our expectations about their effect on estimated tax impacts on FDI from some relatively straightforward theoretical considerations. These argue within the scope of the Zodrow and Mieszkowski (1986) framework and recent considerations by Benassy-Quéré et al. (2007) extending this model. ${ }^{26}$ Benassy-Quéré et al. (2007) rely on two partial effects to compute the overall effect of taxation on FDI. These partial effects measure the ceteris-paribus impacts of respectively the company tax burden and public spending on FDI. Theoretically, they follow from the international arbitrage equilibrium condition which requires equality of marginal after-tax re-

26. The framework builds on governments which maximize a representative agent's utility $U(x, G)$ with $x$ denoting the consumption of a (single) private good and $\mathrm{G}$ as public input used by both households and firms. $\mathrm{G}$ is financed by capital taxes and subject to the budget constraint. Production depends on capital, labor and public inputs. Marginal productivity is decreasing in all input factors. Inputs are complementary, but complementarity is decreasing with increasing inputs. For a comprehensive outline of the model see BenassyQuéré et al. (2007) and for more fundamental version see also Zodrow and Mieszkowski (1986). 
turn and real world market interest rate. Their estimated values are obtained from empirical regressions including both the tax burden as well as expenditure side variables as regressors. The overall effect of tax on FDI, however, according to the Zodrow and Mieszkowski framework takes into account that tax and public expenditure variables are linked via the public budget constraint. It therefore integrates the direct tax effect on FDI and the impact of increasing public inputs financed by the tax receipts. Benassy-Quéré et al. (2007) show that the ceteris-paribus effects of taxes and of public spending still might combine to an overall effect if the budget constraint is imposed ex post. And they indeed find that the computed overall effect of taxation on FDI is moderated by public spending, i.e. the direct adverse tax effect is partially compensated for if tax receipts - at least partially - finance better public inputs. Similar moderating effects can be expected for the inclusion of agglomeration variables.

Meta-analysis offers the opportunity to put the results reported by Benassy-Quéré et al. (2007) into a broader context. Moreover, we do not have to compute the overall tax effect from partial effects by imposing the budget constraint ex post. We instead regard tax effect estimates from primary regressions which do not explicitly control for the (partial) influence of public spending on FDI as estimates of the overall tax effect. This is in line with Brueckner (1979, 1982) who, however, examines the overall effect of public goods on property value in order to test for the nonexistence of Tiebout equilibrium (also known as the Brueckner-Test). Brueckner explicitly recognizes that the inclusion of both tax and expenditure side variables into empirical estimation equations implicitly assumes their ceteris-paribus variation and thus neglects the public budget constraint. He therefore solely estimates the public good coefficient and excludes the tax variable from the regression. Thus, the tax rate is allowed to vary implicitly in response to a change of public spending policies in order to maintain budget balance for the government. The coefficient for public good then gives the estimate for the respective overall effect, covering any possible tax implications. ${ }^{27}$

Drawing an analogy to the context of this meta-study, we are able to statistically compare the overall effect and the ceteris-paribus effect of taxation on FDI. Estimates for the first of both effects are obtained from primary regressions without public spending control, i.e. allowing for implicit variation of expenditures in response to a tax change. The second effect is instead

27. Since Brueckner $(1979,1982)$ argues within the scope of capitalization theory where local governments maximize property values (and not agents' utility) he can explicitly verify if equilibrium is reached by looking at the t-value of the public good variable coefficient estimate. In equilibrium, the expenditure side should have no significant effect on property value as the effect of a marginal increase in public goods is exactly compensated for by the implicit tax reaction. In the Zodrow and Mieszkowski world the moderating impact of public spending can be verified but not efficiency of public good provision. Here, capital is the left-hand variable. Utility and capital maxima, however, do not necessarily coincide. 
obtained from regressions which simultaneously control for the tax burden and public expenditures and thus rest on the assumption of ceteris-paribus variation in these variables. By means of a meta-regression dummy variable taking the value one if primary studies did not explicitly control for public spending and zero otherwise we can statistically test for a moderating impact of the expenditure side. In more econometric terms, we will see if the omission of expenditure side variables biases the estimated tax effects. As we hypothesize public spending to have a moderating effect, we expect a negative coefficient of the dummy variable, i.e. studies not controlling for the ceteris-paribus effect of public spending and thus letting it vary implicitly with a tax change estimate lower adverse tax effects (in absolute terms).

\section{Results}

\subsection{Classical Meta-Analysis}

The results of the classical meta-analysis are shown in Figure 3. It contains the pooled effects resulting from the random effects model only as the Q-test clearly indicates the presence of considerable heterogeneity across studies $(p<0.01)$ for all four estimations. Thus, only the random effects meta-analysis is viable as opposed to fixed effects estimation.

Figure 3: Results of classical random-effects meta-analysis

\begin{tabular}{|l|l|}
\hline & mprec \\
\hline
\end{tabular}

We find that - independent of the percentile of semi-elasticity chosen (min, max or median) the effect of taxation on FDI is significantly different from zero $(\mathrm{p}<0.01)$. The most precise estimates are also highly significant. The pooled effect for the minimum semi-elasticities amounts to 0.173 . In contrast, the upper bound that is set by the pooled effect for the maximum effect sizes is 3.973 . We calculate a pooled effect for the respective median effect sizes of each study which amounts to 1.683. Selecting the most precise estimate from each study gives a pooled semi-elasticity of 1.358 . It should be noted that the results for minimum and 
maximum estimates cannot merely be explained by outliers as these have been eliminated from the sample before. Overall, the pooled estimates define a continuum of plausible values as depicted in Figure 3.

\subsection{Meta-Regressions}

\subsubsection{First Round Meta-Regressions}

\section{Semi-elasticities as dependent variable}

Table 8 shows the results for the broad set of meta-regression estimators applied in a first step. Columns (1) to (7) respectively represent the results from pooled OLS, feasible GLS, fixed-effects meta-regression (FE WLS), mixed-effects meta-regression (ME WLS), fixed effects cluster analysis, random effects cluster analysis via REML and random effects cluster analysis based on GLS.

Clearly, many of the fundamental model characteristics controlled for in this first round estimation show significant coefficients across different estimators. The employment of aggregate data or aggregate data on affiliates, respectively, as opposed to micro level information does indeed lead to higher primary tax-rate elasticities according to (nearly) all estimators. As regards the influence of the tax rate chosen, the effective average tax rates (EATR) generally yield higher primary estimates than those produced when country statutory tax rates are employed. This effect, however, is only significant in the case of pooled OLS, both fixed and random effects meta-regression and random effects GLS. The evidence for the effective marginal tax rate (EMTR) is less clear-cut. Most coefficients indicate a negative but insignificant impact on primary semi-elasticities, only fixed effects meta-regression and the within estimator as well as random effects GLS show significant, but contradictory results. 
Table 8: First round results for semi-elasticties

\begin{tabular}{|c|c|c|c|c|c|c|c|}
\hline \multirow{3}{*}{ Dependent Variable: Semi-elasticities } & \multicolumn{4}{|c|}{ Pooled estimators } & \multicolumn{3}{|c|}{ Cluster-Econometric Estimators } \\
\hline & \multicolumn{2}{|c|}{ Standard Pooled } & \multicolumn{2}{|c|}{ Traditional Meta-Regression } & \multirow{2}{*}{$\begin{array}{c}\begin{array}{c}\text { Fixed } \\
\text { Effects }\end{array} \\
\text { FE }\end{array}$} & \multicolumn{2}{|c|}{ Random Effects } \\
\hline & POLS & FGLS & FE WLS & ME WLS & & RE (REML) & RE (GLS) \\
\hline & $(1)$ & $(2)$ & (3) & (4) & $(5)$ & $(6)$ & $(7)$ \\
\hline \multicolumn{8}{|l|}{ Data Structure (Time Series) } \\
\hline \multirow[t]{2}{*}{ Cross-section } & 1.758 & 0.308 & -0.979 & -0.0164 & 2.710 & 0.424 & 0.615 \\
\hline & $(1.187)$ & $(0.908)$ & $(0.606)$ & $(0.936)$ & $(3.232)$ & $(1.419)$ & $(1.476)$ \\
\hline \multirow[t]{2}{*}{ Panel Data } & -0.365 & -0.385 & -0.262 & $-0.778 * *$ & -2.015 & -0.928 & -0.827 \\
\hline & $(0.350)$ & $(0.361)$ & $(0.518)$ & $(0.303)$ & $(1.569)$ & $(1.067)$ & $(1.119)$ \\
\hline \multirow[t]{2}{*}{$\begin{array}{l}\text { Location Choice } \\
\text { (Continuous Capital Data) }\end{array}$} & -0.890 & -0.692 & 0.052 & -0.895 & $-5.284 * * *$ & $-1.574 * *$ & $-1.368 * *$ \\
\hline & $(1.059)$ & $(0.561)$ & $(0.369)$ & $(0.619)$ & $(1.186)$ & $(0.683)$ & $(0.615)$ \\
\hline \multicolumn{8}{|l|}{ Aggregation Level (Micro data) } \\
\hline \multirow{2}{*}{ Aggregate Data } & $2.303 * * *$ & $1.880 * * *$ & $1.245 * * *$ & $1.857 * * *$ & - & 1.489 & $1.628 * * *$ \\
\hline & $(0.698)$ & $(0.402)$ & $(0.417)$ & $(0.475)$ & & $(0.923)$ & $(0.532)$ \\
\hline \multirow{2}{*}{ Aggregate Data on Affiliates } & $1.894 * *$ & $1.393 * * *$ & $0.922 * *$ & $1.536 * * *$ & $6.116^{* * *}$ & $1.400^{*}$ & $1.408^{* *}$ \\
\hline & $(0.797)$ & $(0.451)$ & $(0.348)$ & $(0.519)$ & $(1.270)$ & $(0.829)$ & $(0.649)$ \\
\hline \multicolumn{8}{|l|}{$\begin{array}{l}\text { Tax Burden Measure } \\
\text { (Country Statutory Rate) }\end{array}$} \\
\hline \multirow[t]{2}{*}{ Micro Average Tax Rate } & -0.360 & -0.227 & $1.875^{* * *}$ & 0.170 & 0.151 & -0.057 & -0.091 \\
\hline & $(1.003)$ & $(0.628)$ & $(0.664)$ & $(1.030)$ & $(1.067)$ & $(0.647)$ & $(0.675)$ \\
\hline \multirow[t]{2}{*}{ Macro Average Tax Rate } & -1.094 & $-1.380 * * *$ & $1.074 * *$ & $-1.722 * *$ & -1.668 & -1.693 & -1.596 \\
\hline & $(0.667)$ & $(0.399)$ & $(0.419)$ & $(0.657)$ & $(1.697)$ & $(1.140)$ & $(1.073)$ \\
\hline \multirow[t]{2}{*}{ State Statutory Tax Rate } & $2.615^{* *}$ & $2.705^{* *}$ & $3.724 * * *$ & $2.553 * * *$ & - & $2.773 * * *$ & $2.717 * *$ \\
\hline & $(1.064)$ & $(1.274)$ & $(0.846)$ & $(0.934)$ & & $(1.061)$ & $(1.151)$ \\
\hline \multirow[t]{2}{*}{ Marginal Effective Tax Rate } & -0.488 & -0.671 & $1.728 * * *$ & -0.337 & $-0.868 *$ & -0.755 & $-0.726^{*}$ \\
\hline & $(0.613)$ & $(0.473)$ & $(0.374)$ & $(0.539)$ & $(0.444)$ & $(0.519)$ & $(0.379)$ \\
\hline \multirow[t]{2}{*}{ Average Effective Tax Rate } & $1.057^{* *}$ & 0.508 & $1.611^{* *}$ & $1.101^{* *}$ & 0.335 & 0.656 & $0.727 * *$ \\
\hline & $(0.503)$ & $(0.360)$ & $(0.608)$ & $(0.531)$ & $(0.411)$ & $(0.556)$ & $(0.355)$ \\
\hline \multirow[t]{2}{*}{ Constant } & 0.942 & $1.625 * *$ & -0.812 & $1.579 * *$ & $4.012 * * *$ & 2.277 & 2.051 \\
\hline & $(0.939)$ & $(0.659)$ & $(0.883)$ & $(0.689)$ & $(1.484)$ & $(1.453)$ & $(1.258)$ \\
\hline Observations & 708 & 708 & 707 & 707 & 708 & 708 & 708 \\
\hline $\mathrm{R}^{2}$ & 0.145 & 0.179 & 0.281 & 0.134 & 0.047 & - & - \\
\hline F-/Wald-test $(\mathrm{H} 0:$ all coefficients $=0)$ & $\mathrm{p}=0.000$ & $\mathrm{p}=0.000$ & $\mathrm{p}=0.000$ & $\mathrm{p}=0.000$ & $\mathrm{p}=0.000$ & $\mathrm{p}=0.000$ & $\mathrm{p}=0.001$ \\
\hline
\end{tabular}


As regards the influence of macroeconomic average tax rates as compared to country statutory rates, most coefficient estimates are negative, but only sometimes significant. Fixed effects meta-regression again shows significant but opposite results for this characteristic. Employing microeconomic average tax rates does not yield different primary semi-elasticities as compared to statutory tax rates according to all meta-regression estimators, again with the exception of traditional fixed effects meta-regression. State statutory tax rates lead to higher tax effect estimates as compared to the use of tax rates at the federal level. Whether crosssectional or panel data is used as opposed to time series analysis is not relevant according to most estimators. Precisely, only mixed effects meta-regression indicates a significant negative impact of using panel data. Studies which examine the location choice of companies systematically measure lower tax effects. For all cluster econometric approaches this effect is significant. Accordingly, the localization of economic rents as compared to marginal investment decisions seems less influenced by taxes. This result would be in line with the findings of De Mooij and Ederveen (2006). It will, however, need further investigation to be clearly verified.

Table 9: Choosing the preferred meta-regression estimator (semi-elasticities)

\begin{tabular}{|c|c|c|c|}
\hline Data characteristic & Test & Result & Preferred estimators \\
\hline \multirow{2}{*}{ 1. Heteroscedasticity? } & & $\chi^{2}(1)=6.98 ; p<0.01$ & \multirow{2}{*}{$\begin{array}{l}\text { FGLS, FE WLS, ME } \\
\text { WLS }\end{array}$} \\
\hline & White test & $\chi^{2}(30)=121.57 ; p<0.01$ & \\
\hline $\begin{array}{l}\text { 2. Unexplained } \\
\text { heterogeneity? }\end{array}$ & $\mathrm{Q}$ - test & $Q=6726.37 ; p<0.01$ & FGLS, ME WLS \\
\hline \multirow{2}{*}{$\begin{array}{l}\text { 3. Study-specific ef- } \\
\text { fects? }\end{array}$} & Breusch Pagan LM test & $\chi^{2}(1)=12.63 ; p<0.01$ & \multirow{2}{*}{$\begin{array}{l}\text { Cluster-econometrics } \\
(\mathrm{FE}, \mathrm{RE})\end{array}$} \\
\hline & Wooldridge-type test & $\mathrm{SN}=1.86 ; \mathrm{p}=0.03$ & \\
\hline 4. Endogeneity? & Robust Hausman test & $\mathrm{F}(8,41)=19.71 ; \mathrm{p}<0.01$ & $\mathrm{FE}$ \\
\hline \multicolumn{4}{|c|}{$\begin{array}{l}\text { 1. Heteroscedasticity: Breusch Pagan and White test are both based on test statistics which are } \chi^{2} \text {-distributed } \\
\text { under the null of no heteroscedasticity. In the present case both tests reject the null of no heteroscedasticity at } \\
\text { very high significance levels. 2. Unexplained heterogeneity: The Q-test is based on a test statistic which is } \chi^{2} \text { - } \\
\text { distributed under the null of no heterogeneity. Here, the null of no heterogeneity is rejected at very high signi- } \\
\text { ficance levels. 3. Study-specific effects: The Breusch Pagan LM and the Wooldridge-type assume a null of no } \\
\text { unobserved study-specific effects. Under the null the Breusch Pagan LM test is } \chi^{2} \text {-distributed, while the Wool- } \\
\text { dridge-type test is asymptotically distributed as standard normal under the null. Both tests reject the null at high } \\
\text { significance levels. 4. Endogeneity: F-test in the context of an artifical regression following Wooldridge } \\
\text { (2002), also see the explanations in the text. The null of no correlation between the study-specific unobservable } \\
\text { effect and the moderator variables is rejected at high significance levels. }\end{array}$} \\
\hline
\end{tabular}

Although most of the applied meta-regression estimators give congruent indications as regards the influence of study characteristics on primary tax effect estimates, they rely on different assumptions regarding the characteristics of the meta-data, as has been outlined in sec- 
tion 5. We therefore employ the series of tests described in section 6 in order to find the estimator which is most suitable for the actual data at hand. The test results are given in Table 9.

First, we run a standard RESET test on the basic specification employment in these first round estimations. The result $(\mathrm{F}(3,694)=13.93, \mathrm{p}<0.01)$ forces us to reject the null of correct specification. We truncate our meta-sample at the extremes and successively rerun the test until the null is no longer rejected. Comparing the implications of running the regressions on this truncated sample, no qualitative differences occur. We thus go on with the meta-regression based on the full sample. In a next step we find clear evidence for heteroscedasticity in the meta-regression error terms by means of a Breusch Pagan LM test $\left(\chi^{2}(1)=6.98, p<0.01\right)$ and a White test $\left(\chi^{2}(30)=121.57, \mathrm{p}<0.01\right)$. This result clearly favors meta-regression estimators which explicitly cope with heteroscedasticity. As a $Q$-test $(\mathrm{Q}=6726.37, \mathrm{p}<0.01)$ run after the mixed-effects meta-regression identifies remaining unexplained heterogeneity, we can exclude fixed effects WLS from the set of applicable estimators. In order to assess whether meta-regression models should account for a nested error structure, we add to the standard Breusch Pagan LM test $\left(\chi^{2}(1)=12.63, \mathrm{p}<0.01\right)$ the Wooldridge-type test (test $=1.86, \mathrm{p}=$ 0.03) outlined above. Apparently, unobserved study-effects are present. Cluster econometric techniques are thus preferred over pooled estimators. As we find clear evidence for endogeneity, only the fixed effects cluster estimator is viable. To gain insights into the effects of variables which are constant within studies we also apply the FEVD technique. Another robustness check includes a traditional mixed effects meta-regression based on WLS.

\section{T-values as dependent variable}

Replacing semi-elasticities by primary t-values on the left-hand side of the meta-regression equation implies that resulting meta-coefficients do not only measure the impact of considered meta-regressors on mere effect size. In contrast, t-values by definition also contain information about primary estimate precision. Thus, both types of analysis should be regarded as complementary rather than substitutes. In the light of the insights gained from both analyses some statements made solely on the grounds of semi-elasticities might be put into perspective. 
Table 10: First round results for t-values

\begin{tabular}{|c|c|c|c|c|c|}
\hline \multirow{3}{*}{$\begin{array}{l}\text { Dependent Variable: } T \text { - } \\
\text { values }\end{array}$} & \multirow{2}{*}{\multicolumn{2}{|c|}{ Pooled Estimators }} & \multicolumn{3}{|c|}{$\begin{array}{l}\text { Cluster-Econometric Estimators } \\
\end{array}$} \\
\hline & & & \multirow{2}{*}{$\begin{array}{c}\text { Fixed Effects } \\
\text { FE } \\
\end{array}$} & \multicolumn{2}{|c|}{ Random Effects } \\
\hline & POLS & FGLS & & RE (REML) & RE (GLS) \\
\hline & $(1)$ & $(2)$ & $(3)$ & (4) & $(5)$ \\
\hline \multicolumn{6}{|l|}{$\begin{array}{l}\text { Data Structure (Time Se- } \\
\text { ries) }\end{array}$} \\
\hline \multirow[t]{2}{*}{ Cross-section } & $2.012^{* *}$ & $2.147 * * *$ & 0.697 & -0.007 & 0.006 \\
\hline & $(0.895)$ & $(0.641)$ & $(1.193)$ & $(1.271)$ & $(1.021)$ \\
\hline \multirow[t]{2}{*}{ Panel Data } & $1.078 * *$ & $0.920^{*}$ & 1.024 & 0.229 & 0.228 \\
\hline & $(0.454)$ & $(0.484)$ & $(0.752)$ & $(0.896)$ & $(0.731)$ \\
\hline \multirow[t]{2}{*}{$\begin{array}{l}\begin{array}{l}\text { Location Choice } \\
\text { (Continuous Capital Data) }\end{array} \\
\end{array}$} & -0.839 & -0.630 & $-1.348 * * *$ & $-0.901 *$ & $-0.897 * *$ \\
\hline & $(0.523)$ & $(0.382)$ & $(0.402)$ & $(0.484)$ & $(0.351)$ \\
\hline \multicolumn{6}{|l|}{$\begin{array}{l}\text { Aggregation Level (Micro } \\
\text { data) }\end{array}$} \\
\hline \multirow[t]{2}{*}{ Aggregate Data } & -0.131 & -0.127 & - & -0.233 & -0.241 \\
\hline & $(0.657)$ & $(0.681)$ & & $(0.881)$ & $(0.735)$ \\
\hline \multirow[t]{2}{*}{ Aggregate Data on Affiliates } & $-1.051 * *$ & $-1.247 * * *$ & $1.046^{* *}$ & -0.681 & -0.698 \\
\hline & $(0.413)$ & $(0.397)$ & $(0.445)$ & $(0.768)$ & $(0.556)$ \\
\hline \multicolumn{6}{|l|}{$\begin{array}{l}\text { Tax Burden Measure } \\
\text { (Country Statutory Rate) }\end{array}$} \\
\hline \multirow[t]{2}{*}{ Micro Average Tax Rate } & -0.832 & $-1.088^{*}$ & 0.883 & 0.565 & 0.557 \\
\hline & $(1.252)$ & $(0.570)$ & $(0.697)$ & $(0.498)$ & $(0.619)$ \\
\hline \multirow[t]{2}{*}{ Macro Average Tax Rate } & -1.374 & $-1.585^{* *}$ & $-2.369 * * *$ & $-1.688^{*}$ & $-1.681 * *$ \\
\hline & $(1.127)$ & $(0.648)$ & $(0.750)$ & $(0.862)$ & $(0.729)$ \\
\hline \multirow[t]{2}{*}{ State Statutory Tax Rate } & $-2.042 * *$ & $-2.030 * * *$ & - & -0.914 & -0.922 \\
\hline & $(0.892)$ & $(0.546)$ & & $(1.162)$ & $(0.780)$ \\
\hline \multirow[t]{2}{*}{ Marginal Effective Tax Rate } & -0.994 & $-1.077^{*}$ & -0.157 & -0.237 & -0.241 \\
\hline & $(1.147)$ & $(0.603)$ & $(0.296)$ & $(0.356)$ & $(0.302)$ \\
\hline \multirow[t]{2}{*}{ Average Effective Tax Rate } & 0.0862 & 0.261 & 0.230 & 0.204 & 0.204 \\
\hline & $(0.972)$ & $(0.399)$ & $(0.374)$ & $(0.393)$ & $(0.343)$ \\
\hline \multirow[t]{2}{*}{ Constant } & $2.809 * *$ & $2.952 * * *$ & $1.720 * *$ & $3.111 * *$ & $3.119 * * *$ \\
\hline & $(1.139)$ & $(0.942)$ & $(0.708)$ & $(1.232)$ & $(0.928)$ \\
\hline Observations & 729 & 729 & 729 & 729 & 729 \\
\hline $\mathrm{R}^{2}$ & 0.121 & 0.190 & 0.022 & & \\
\hline $\begin{array}{l}\text { F-/Wald-test } \\
(\text { H0: all coefficients }=0)\end{array}$ & $\mathrm{p}=0.000$ & $\mathrm{p}=0.000$ & $\mathrm{p}=0.001$ & $\mathrm{p}=0.089$ & $\mathrm{p}=0.003$ \\
\hline \multicolumn{6}{|c|}{$\begin{array}{l}\text { Clustered standard errors (POLS, FGLS) or robust standard errors (FE, REML, RE GLS) in parentheses. } * * * / * * / * \text { denotes signi } \\
\text { ficance at the } 1 \% / 5 \% / 10 \% \text { level. Primary t-values have been multiplied by }(-1) \text {. All study/model characteristics are coded a } \\
\text { dummy variables. Thus, a base model represents the characteristics redundant to the variables explicitly included. The base cha } \\
\text { racteristics are indicated in parenthesis for each study dimension. Estimated coefficients of the dummies indicate the effect or } \\
\text { primary t-values of choosing a characteristic in lieu of the base specification. Abbreviations for the employed estimators are ex } \\
\text { plained in the text. }\end{array}$} \\
\hline
\end{tabular}

The first round results for the meta-regressions which use primary t- and z-values as dependent variable are given in Table 10. As compared to the first round results for the semi-elasticities the influence of many fundamental primary characteristics are less significant. Neither the employment of effective tax rates (as opposed to the country statutory rate) nor the use of aggregate data (as opposed to micro data) has a significant impact on t-values according to all or all but one of the applied estimators. Strikingly, the impact of model and study characteristics on semi-elasticities or t-values respectively is not always of the same sign. The state tax rate here shows negative coefficients and the effect is significant. According to most estimators, the macroeconomic average tax rate is a rather crude measure to capture tax incentives. It leads to much lower primary t-values as compared to the statutory rate. Furthermore, aggre- 
gate studies do not yield higher t-values as compared to micro data studies. As for studies using aggregate data on affiliates the evidence is not quite clear, since we find significant effects with different signs according to the different estimators. However, in any case the considerable bias in semi-elasticities does not seem to fully translate into higher t-values, i.e. significance of the tax effects. The presumed upward bias due to endogeneity problems in aggregate studies thus seems to be counteracted by higher standard errors of the primary tax effect estimates. Attributing this observation to problems of measurement error in the context of aggregate studies seems plausible. Again, the influence of taxes is less important for the decision on the location of economic rents as compared to investment decisions conditional on location choice. So we measure generally lower t-values for studies analyzing location choice as compared to studies examining continuous FDI. However, similar to what we find in the analysis focusing on semi-elasticities, the significance of this effect becomes not absolutely clear by looking at the results across Table 10.

Table 11: Choosing the preferred meta-regression estimator (t-values)

\begin{tabular}{llll}
\hline \hline Data characteristic & Test & Result & Preferred estimators \\
\hline \hline 1. Heteroscedasticity? & Breusch Pagan LM test & $\chi^{2}(1)=10.19, \mathrm{p}<0.01$ & \\
& White test & $\chi^{2}(30)=41.18, \mathrm{p}=0.08$ & FGLS \\
\hline \hline $\begin{array}{l}\text { 2. Study-specific ef- } \\
\text { fects? }\end{array}$ & Breusch Pagan LM test & $\chi^{2}(1)=102.95, \mathrm{p}<0.01$ & $\begin{array}{l}\text { Cluster-econometrics } \\
\text { (FE, RE) }\end{array}$ \\
\hline \hline 3. Endogeneity? & Wooldridge-type test & test $=1.54, \mathrm{p}=0.06$ & \\
\hline \hline
\end{tabular}

See Footnote of Table 9 for explanations.

Starting with the series of test, we compute a RESET test for misspecification $(F(3,715)=2.43, p=0.06)$ and find only relatively weak evidence for a rejection of the null. However, we still repeat the same procedure as in the case of semi-elasticities until the null is clearly accepted. Again, we find no qualitative differences in results for the regressions on the truncated sample and go on with the analysis on the full meta-dataset. The subsequent tests and resulting statistics used to identify the preferred meta-regression estimator for the analysis of t-values are indicated in Table 11. Again, we find clear evidence for heteroscedasticity. Study-specific unobserved effects are present according to the standard Breusch Pagan test as well as to the more robust Wooldridge-type test. The robust Hausman test based on the artificial regression approach, however, reveals an endogeneity problem linked to the unobser- 
vables. Thus, our preferred estimator is the fixed effects cluster estimator. In order to gain insights on the effect of within-invariant variables we again apply the FEVD technique. Another robustness check will also look at FGLS results.

\subsubsection{Second Round Meta-Regressions}

\section{Semi-elasticities as dependent variable}

The results for the second round meta-regression with semi-elasticities on the left-hand side are indicated in Table 12. First, we extend the first round specification by including the newly coded model characteristics (Column 1). Obviously, splitting the effective forward-looking tax rates in bilateral and unilateral tax burden measures reveals that particularly the bilateral measures seem to capture adverse tax effects on foreign direct investments. Both the bilateral marginal tax burden measures and the bilateral average tax rate significantly raise primary tax effect estimates as compared to statutory rates. Strikingly, employing the domestic unilateral effective tax rates (EATR and EMTR) leads to significantly lower estimated semi-elasticities as compared to the use of statutory rates. These measures might thus indeed mix aspects of competitive (tax) advantage for multinationals over domestic firms and pure adverse tax effects. This supports the reasoning of Egger et al. (2008), who explicitly prefer bilateral tax burden measures in the FDI context. However, the significantly negative coefficient of the effective average unilateral tax rates is not robust across specifications. This seems intuitively plausible since the EATR is to a considerable extent driven by the statutory tax rate.

Country fixed effects significantly reduce primary tax effect estimates. They thus do indeed show the opposite sign of the coefficient we find for aggregate studies. The latter is still highly significant and positive for studies based on aggregate data on affiliates. In the left four columns of Table 12 we could not estimate a coefficient for aggregate studies due to a lack of within-study variation. The inclusion of time fixed effects, however, does exert no effect on estimated semi-elasticities. Strikingly, regarding the implications of considering the public expenditure side in primary regressions, we do not identify a significant bias. Also the sign of the effect of not-including a public spending control is not as expected. In other words, allowing public spending to adjust to tax changes and thus not including it into the primary regression does not lower the estimated adverse tax effects. As this result contradicts theoretical presumptions, it might at least in parts be explained by hitherto insufficiently precise proxies for relevant public inputs from the companies' point of view. 
Table 12: Second round results for semi-elasticities

\begin{tabular}{|c|c|c|c|c|c|c|c|}
\hline \multirow[b]{2}{*}{ Dependent Variable: Semi-elasticities } & \multicolumn{4}{|c|}{ Extensions } & \multicolumn{3}{|c|}{ Robustness Checks } \\
\hline & $\begin{array}{c}\text { FE-Extension } \\
1\end{array}$ & $\begin{array}{c}\text { FE-Extension } \\
2\end{array}$ & $\begin{array}{c}\text { FE-Extension } \\
3\end{array}$ & $\begin{array}{c}\text { FE-Extension } \\
4\end{array}$ & $\begin{array}{l}\text { Robustness } \\
\text { Check } 1\end{array}$ & $\begin{array}{c}\text { Robustness } \\
\text { Check } 2\end{array}$ & $\begin{array}{c}\text { Robustness } \\
\text { Check } 3\end{array}$ \\
\hline & $(1)$ & $(2)$ & $(3)$ & $(4)$ & (5) & $(6)$ & $(7)$ \\
\hline \multicolumn{8}{|l|}{ Data Structure (Time Series) } \\
\hline \multirow[t]{2}{*}{ Cross-section } & 2.263 & 2.285 & 3.953 & 5.167 & 5.167 & -1.087 & -1.805 \\
\hline & $(3.233)$ & $(3.219)$ & $(2.523)$ & $(3.585)$ & $(3.659)$ & $(0.788)$ & $(2.113)$ \\
\hline \multirow{2}{*}{ Panel Data } & -0.713 & -0.368 & 0.746 & 1.153 & 1.153 & 0.155 & -2.594 \\
\hline & $(1.601)$ & $(1.730)$ & $(1.316)$ & $(2.269)$ & $(1.268)$ & $(0.752)$ & $(1.776)$ \\
\hline \multirow[t]{2}{*}{$\begin{array}{l}\begin{array}{l}\text { Location Choice } \\
\text { (Continuous Capital Data) }\end{array} \\
\end{array}$} & $-5.284 * * *$ & $-5.067 * * *$ & $-3.515 * * *$ & $-4.612 * * *$ & $-4.612 * * *$ & $-4.612 * * *$ & -0.968 \\
\hline & $(1.189)$ & $(1.256)$ & $(1.233)$ & $(1.282)$ & $(0.922)$ & $(0.953)$ & $(0.662)$ \\
\hline \multicolumn{8}{|l|}{ Aggregation Level (Micro data) } \\
\hline \multirow[t]{2}{*}{ Aggregate Data } & - & - & - & - & $3.945 * * *$ & $2.367 * * *$ & $2.515 * * *$ \\
\hline & & & & & $(0.131)$ & $(0.183)$ & $(0.574)$ \\
\hline \multirow[t]{2}{*}{ Aggregate Data on Affiliates } & $5.548 * * *$ & $5.304 * * *$ & $3.673 * * *$ & $4.861 * * *$ & $4.861 * * *$ & $4.861 * * *$ & $2.347 * * *$ \\
\hline & $(1.243)$ & $(1.327)$ & $(1.282)$ & $(1.347)$ & $(1.202)$ & $(1.280)$ & $(0.474)$ \\
\hline \multicolumn{8}{|l|}{$\begin{array}{l}\text { Tax Burden Measure } \\
\text { (Country Statutory Rate) }\end{array}$} \\
\hline \multirow[t]{2}{*}{ Micro Average Tax Rate } & -0.237 & -0.203 & -0.00450 & -0.0478 & -0.0478 & -0.0478 & -0.130 \\
\hline & $(1.074)$ & $(1.065)$ & $(0.735)$ & $(1.069)$ & $(0.578)$ & $(0.593)$ & $(0.698)$ \\
\hline \multirow[t]{2}{*}{ Macro Average Tax Rate } & -2.594 & $-2.725^{*}$ & -0.960 & -2.553 & -2.553 & $-2.247 * * *$ & -0.522 \\
\hline & $(1.627)$ & $(1.651)$ & $(0.943)$ & $(1.659)$ & $(1.561)$ & $(0.753)$ & $(1.266)$ \\
\hline \multirow[t]{2}{*}{ State Statutory Tax Rate } & - & - & - & - & $3.495 * * *$ & $4.467 * * *$ & $3.845^{*}$ \\
\hline & & & & & $(0.289)$ & $(0.775)$ & $(2.065)$ \\
\hline \multirow[t]{2}{*}{ Marginal Effective Tax Rate } & $-1.424 * *$ & $-1.411 * *$ & $-0.851 * *$ & $-1.405 * *$ & $-1.405 * * *$ & $-1.405 * * *$ & -0.235 \\
\hline & $(0.572)$ & $(0.569)$ & $(0.348)$ & $(0.570)$ & $(0.396)$ & $(0.425)$ & $(0.665)$ \\
\hline \multirow[t]{2}{*}{ Average Effective Tax Rate } & -0.666 & -0.655 & $-0.733 * *$ & -0.663 & $-0.663^{*}$ & $-0.663^{*}$ & 0.086 \\
\hline & $(0.438)$ & $(0.433)$ & $(0.319)$ & $(0.426)$ & $(0.397)$ & $(0.390)$ & $(0.343)$ \\
\hline \multirow[t]{2}{*}{ Bilateral Marginal Effective Tax Rate } & $1.099 * * *$ & $1.123 * * *$ & $0.949 * * *$ & $0.979 * * *$ & $0.979 * * *$ & $0.979 * * *$ & 0.377 \\
\hline & $(0.315)$ & $(0.315)$ & $(0.257)$ & $(0.328)$ & $(0.309)$ & $(0.300)$ & $(0.717)$ \\
\hline \multirow[t]{2}{*}{ Bilateral Average Effective Tax Rate } & $3.566 * * *$ & $3.562 * * *$ & $3.144 * * *$ & $3.465 * * *$ & $3.465 * * *$ & $3.465 * * *$ & $1.806^{* * *}$ \\
\hline & $(0.538)$ & $(0.538)$ & $(0.479)$ & $(0.544)$ & $(0.438)$ & $(0.452)$ & $(0.604)$ \\
\hline \multirow[t]{2}{*}{ No Control for Public Spending (Control) } & 0.460 & 0.466 & 0.253 & 0.507 & 0.507 & 0.507 & 0.408 \\
\hline & $(0.863)$ & $(0.864)$ & $(0.533)$ & $(0.942)$ & $(0.766)$ & $(0.682)$ & $(0.373)$ \\
\hline
\end{tabular}




\begin{tabular}{|c|c|c|c|c|c|c|c|}
\hline \multirow{3}{*}{ Dependent Variable: Semi-elasticities } & \multicolumn{4}{|c|}{ Extensions } & \multicolumn{3}{|c|}{ Robustness Checks } \\
\hline & $\begin{array}{c}\text { FE-Extension } \\
1 \\
\end{array}$ & $\begin{array}{c}\text { FE-Extension } \\
2 \\
\end{array}$ & $\begin{array}{c}\text { FE-Extension } \\
3 \\
\end{array}$ & $\begin{array}{c}\text { FE-Extension } \\
4 \\
\end{array}$ & $\begin{array}{c}\text { Robustness } \\
\text { Check 1 }\end{array}$ & $\begin{array}{c}\text { Robustness } \\
\text { Check } 2\end{array}$ & $\begin{array}{c}\text { Robustness } \\
\text { Check } 3 \\
\end{array}$ \\
\hline & $(1)$ & $(2)$ & $(3)$ & $(4)$ & $(5)$ & $(6)$ & $(7)$ \\
\hline \multicolumn{8}{|l|}{ Specification (no Fixed Effects) } \\
\hline \multirow[t]{2}{*}{ Time Fixed Effects } & -0.332 & -0.422 & 0.389 & -0.381 & -0.381 & -0.381 & $-0.970 *$ \\
\hline & $(0.530)$ & $(0.512)$ & $(0.466)$ & $(0.513)$ & $(0.497)$ & $(1.014)$ & $(0.518)$ \\
\hline \multirow[t]{2}{*}{ Country Fixed Effects } & $-1.302 * * *$ & $-1.312 * * *$ & $-1.062 * * *$ & $-1.246 * * *$ & $-1.246 * * *$ & $-1.246 * * *$ & -0.468 \\
\hline & $(0.298)$ & $(0.297)$ & $(0.239)$ & $(0.325)$ & $(0.246)$ & $(0.440)$ & $(0.311)$ \\
\hline OLS Estimation (other than OLS) & & & & $-1.229 * * *$ & $-1.229 * * *$ & $-1.229 * * *$ & $-0.655^{*}$ \\
\hline \multicolumn{8}{|l|}{ Type of Industry (not specified) } \\
\hline \multirow[t]{2}{*}{ Manufacturing Industry } & & & & $0.971^{*}$ & $0.971 * *$ & $0.971 * *$ & $0.856^{* *}$ \\
\hline & & & & $(0.515)$ & $(0.452)$ & $(0.478)$ & $(0.405)$ \\
\hline \multirow[t]{2}{*}{ Financial Services } & & & & 0.891 & $0.891^{*}$ & $0.891 * *$ & $1.599^{*}$ \\
\hline & & & & $(0.705)$ & $(0.465)$ & $(0.411)$ & $(0.900)$ \\
\hline \multicolumn{8}{|l|}{ Finance (not specified) } \\
\hline \multirow[t]{2}{*}{ Retained earnings } & & & & 1.168 & 1.168 & 1.168 & 0.083 \\
\hline & & & & $(1.437)$ & $(0.949)$ & $(1.101)$ & $(0.843)$ \\
\hline Transfers of Funds & & & & 0.667 & 0.667 & 0.667 & -0.453 \\
\hline \multicolumn{8}{|l|}{ Double Taxation Relief System (not specified) } \\
\hline \multirow[t]{2}{*}{ Credit System } & & & & 0.211 & 0.211 & 0.211 & -0.145 \\
\hline & & & & $(0.788)$ & $(0.496)$ & $(0.499)$ & $(0.615)$ \\
\hline \multirow[t]{2}{*}{ Exemption System } & & & & 0.107 & 0.107 & 0.107 & -0.498 \\
\hline & & & & $(0.787)$ & $(0.496)$ & $(0.505)$ & $(0.521)$ \\
\hline \multicolumn{8}{|l|}{ Control Variables (not included) } \\
\hline \multirow[t]{2}{*}{ Control for Home Tax } & & & & -1.979 & $-1.979^{*}$ & $-1.979 *$ & -0.221 \\
\hline & & & & $(1.829)$ & $(1.089)$ & $(1.171)$ & $(0.496)$ \\
\hline \multirow[t]{2}{*}{ GDP } & & & & -0.197 & -0.197 & $-1.016^{* *}$ & 0.178 \\
\hline & & & & $(1.943)$ & $(2.300)$ & $(0.413)$ & $(0.585)$ \\
\hline \multirow[t]{2}{*}{ Openness } & & & & $-1.388 * * *$ & $-1.388 * * *$ & $-2.004 * * *$ & $-1.822 * * *$ \\
\hline & & & & $(0.353)$ & $(0.373)$ & $(0.392)$ & $(0.224)$ \\
\hline \multirow[t]{2}{*}{ Agglomeration Effects } & & & & 1.013 & 1.013 & -0.001 & 0.053 \\
\hline & & & & $(2.160)$ & $(1.568)$ & $(0.214)$ & $(0.541)$ \\
\hline \multirow[t]{2}{*}{ Exchange Rate } & & & & 1.178 & 1.178 & 1.178 & 0.695 \\
\hline & & & & $(1.808)$ & $(2.096)$ & $(1.586)$ & $(0.765)$ \\
\hline \multirow[t]{2}{*}{ Wage } & & & & -1.258 & -1.258 & 0.200 & 0.456 \\
\hline & & & & $(0.889)$ & $(0.926)$ & $(0.511)$ & $(0.419)$ \\
\hline
\end{tabular}




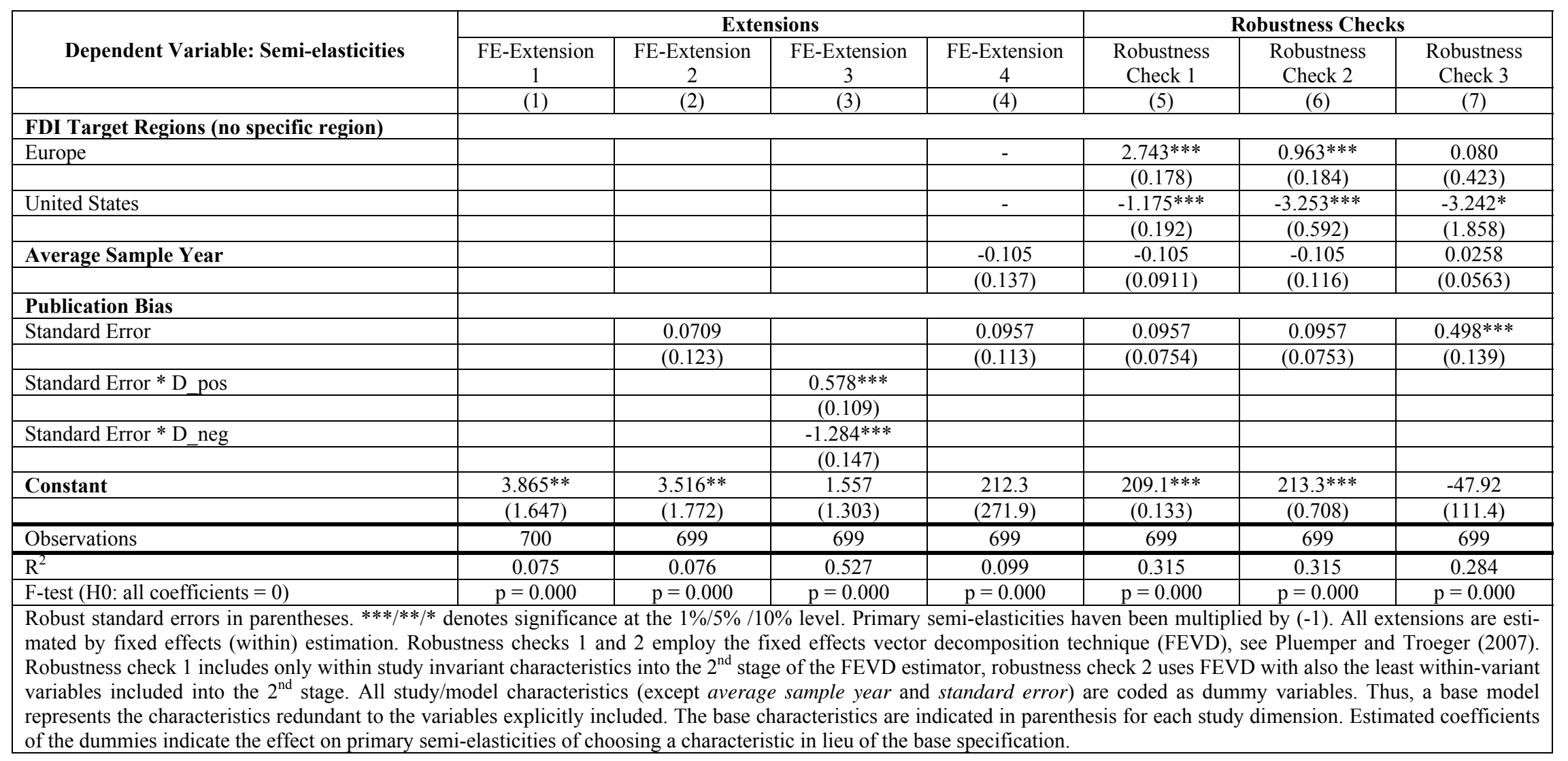


Another aspect which has so far not been considered in surveys of the literature on FDI and taxation is publication bias. In Column 2 we consider unidirectional publication bias by including the standard error of the primary estimates into the meta-regression. However, studies on FDI and taxation do not seem to be significantly biased according to this approach. Researchers do not try to raise effect size estimates in response to imprecise estimation techniques. The conclusions are, however, quite different if we look at what is found for the more sophisticated approach introduced by Bom and Ligthart (2008). Positive tax effect estimates apparently are pushed even more if estimates tend to be imprecise. Negative tax effect estimates are even more negative in response to high standard errors. Both effects are significant. Bidirectional publication bias thus seems to be present. However, it is not persuasive that researchers who identify attracting effects of taxation on FDI tend to insist on their findings and try to push them towards significance. According to the $\mathrm{R}^{2}$ of the regression in Column 3 the approach by Bom and Ligthart leads to a veritable jump in the explained variation of primary estimates. However, by construction, the interaction terms (Standard Error * D_pos) and (Standard Error * D_neg) show a fairly high (within-) variation as compared to the other regressors. This, however, fosters significance of the two examined correlations. For this reason we hesitate to interpret the corresponding results as revealing causality and rely on the unidirectional approach in the remaining meta-regressions.

In Column 4 of Table 12 we estimate a fully extended meta-regression with additional study and model characteristics which might admittedly have an impact on primary study results (De Mooij and Ederveen 2003, 2005, 2006). Almost all results are in line with the findings of De Mooij and Ederveen $(2003,2005,2006)$. The system of double taxation avoidance in the parent country or the mode of finance (retained earnings vs. transfer of funds) does not influence the estimated tax effects. Primary studies controlling for the openness of the target economies yield significantly smaller semi-elasticities while most of other primary control variables (GDP, Agglomeration effects, Exchange rates and wage) do not have significant impacts on measured tax effects. ${ }^{28}$ The mean sample year also has no impact on primary estimates of the tax effect on FDI. Controlling for home country taxes exerts no significant effect on primary tax effect estimates. The respective meta-coefficient, however, has a negative sign. Interestingly, studies who apply OLS as opposed to any other estimation technique (e.g. instrumental variable estimators) significantly measure lower tax effects on FDI. Finally, we find that studies explicitly concentrating on manufacturing industries find higher effect esti-

28. De Mooij and Ederveen (2005), however, found that controlling for agglomeration effects had significant impacts on primary estimates. 
mates as opposed to those which do not specify the sectors covered by their analyses. The inclusion of all these meta-regressors do not change the results found before. Please note that all our second round results show no significant effect of the data structure - panel, crosssection or time series - on primary results. This is in contrast to earlier findings of De Mooij and Ederveen and might be due to the partly modified study classification.

The last three columns of Table 12 represent robustness checks. In Column 5 we estimate the full model via FEVD. This is particularly interesting as it allows for the identification of the effects of study-level variables (or within-invariant model-level characteristics) on primary semi-elasticities. Besides the statutory tax rate the focus, of course, is on the coefficient estimate for aggregate data studies. For both of these variables we find the first stage regression results confirmed as the measured effects are positive and highly significant. In the course of this robustness check we also take a look at FDI target regions considered in primary work. Precisely, we test whether tax effects significantly differ if studies focus exclusively either on European countries or the US as FDI target. This was not possible as long as standard fixed effects estimation was employed. The benchmark model for both characteristics is defined by those studies which examine a mix of regions, typically a broad set of OECD countries. Apparently estimated adverse tax effects on FDI are stronger for only Europe as compared to the benchmark, while the tax effect measured for the US is below the benchmark. As to the implications regarding the estimated coefficients of the other meta-regressors, only changes in significance might occur. This is the case for the effects estimated for the average effective tax rate and for models estimated solely on information about financial service industries. In Column 6 we make use of the possibility to include not only purely within-invariant variables into the second stage of the FEVD estimator, but we further add the most rarely changing model-level variables to this stage of the estimation procedure. This, however, does not change the results except that the effect for GDP control now turns out to be significant. In Column 7 we again look at results from WLS mixed effects meta-regression. We find that significance for some of the effects identified is lost. Particularly, this holds for the influence of target regions on primary semi-elasticities as well as for the effects of employing bilateral marginal tax rates or location choice analysis. Additionally, we now find the effects of the inclusion of time fixed effects into primary regressions to be significant, while fixed effects no longer seem to change primary results significantly. But many results also do not change with respect to significance. This is particularly the case for the effect of using aggregate data and bilateral average tax rates. 


\section{T-values as dependent variable}

For the second round computations with t-values on the left-hand side (Results: Table 13) a set of specifications and estimators similar to the one applied to semi-elasticities is chosen. An important difference, however, is that we cannot control for the (non-)existence of publication bias in the literature by including primary standard errors on the right-hand side of the meta-regression because this would imply simultaneity problems. As a solution we simply include a dummy reflecting the publication status of primary work into the regressions. As publication status represents a study-level characteristic which is by definition invariant within studies we unfortunately cannot use standard within estimation to examine publication bias. Therefore we address this issue later in the course of two robustness checks we perform on the basis of FEVD (see Columns (3) and (4) in Table 13). As a third robustness check Column (5) in Table 13 is estimated by pooled FGLS. Generally, the results - as displayed in Table 13 - are again fairly robust across specifications. However, for some regressors we see switches with respect to the apparent significance of the effects they exert on t-values.

In principle, the presumptions from the first round estimates are confirmed. While aggregate studies produce higher semi-elasticities as compared to micro data studies they do not yield more significant tax effects. According to the results in Columns (3) and (4), t-values are even significantly mitigated. The picture is somewhat different in the case of studies using aggregate affiliate data. Here, a higher significance of primary tax effects is generally identified. To investigate this point in more depth we run a simple POLS regression of primary effect standard errors on the examined study and model characteristics. ${ }^{29}$ Indeed we find that aggregate studies as well as studies based on aggregate affiliate data produce significantly higher standard errors as compared to micro data studies. And indeed, this effect is most pronounced for aggregate studies.

According to all specifications estimated by the consistent fixed effects estimators, we finally confirm that the decision where to locate economic rents indeed responds less to taxes than continuous investment decisions at the margin. This proposition has already been put forward by De Mooij and Ederveen (2006). It, however, contradicts the general presumptions drawn from the fact that estimated coefficient for marginal tax burden measures (e.g. EMTR) are generally lower (again in absolute terms) than those for their inframarginal ones. This often is seen as an implicit indication for relatively low tax responsiveness of marginal investment decisions (see. e.g. Devereux and Lockwood 2006). A plausible explanation of the results

29. Results are available upon request. 
obtained from the meta-regressions might be based on the fact that decisions at the margin are by definition very difficult to capture - even on the basis of high quality continuous capital data. For example, Overesch and Wamser (2008b) found that the EATR effect on continuous investment decisions conditional on location choice is still higher than the EMTR effect.

Table 13: Second round results for t-values

\begin{tabular}{|c|c|c|c|c|c|}
\hline \multirow[b]{2}{*}{ Dependent Variable: T-values } & \multicolumn{2}{|c|}{$\begin{array}{c}\text { Extensions } \\
\end{array}$} & \multicolumn{3}{|c|}{ Robustness Checks } \\
\hline & $\begin{array}{l}\text { FE-Extension } \\
1\end{array}$ & $\begin{array}{l}\text { FE-Extension } \\
2\end{array}$ & $\begin{array}{l}\text { Robustness } \\
\text { Check } 1\end{array}$ & $\begin{array}{l}\text { Robustness } \\
\text { Check } 2\end{array}$ & $\begin{array}{c}\text { Robustness } \\
\text { Check } 3\end{array}$ \\
\hline & $(1)$ & $(2)$ & (3) & (4) & $(5)$ \\
\hline \multicolumn{6}{|l|}{ Data Structure (Time Series) } \\
\hline \multirow[t]{2}{*}{ Cross-section } & -1.311 & -0.275 & -0.275 & $-3.246^{* * *}$ & -2.582 \\
\hline & $(1.300)$ & $(1.622)$ & $(1.427)$ & $(0.472)$ & $(1.631)$ \\
\hline \multirow[t]{2}{*}{ Panel Data } & 1.009 & 0.876 & 0.876 & $-1.881 * * *$ & -1.781 \\
\hline & $(1.167)$ & $(1.333)$ & $(0.724)$ & $(0.465)$ & $(1.359)$ \\
\hline \multirow[t]{2}{*}{$\begin{array}{l}\text { Location Choice } \\
\text { (Continuous Capital Data) }\end{array}$} & $-1.554 * * *$ & $-1.697 * * *$ & $-1.697 * * *$ & $-1.697 * * *$ & $-1.156 * *$ \\
\hline & $(0.466)$ & $(0.542)$ & $(0.352)$ & $(0.347)$ & $(0.492)$ \\
\hline \multicolumn{6}{|l|}{ Aggregation Level (Micro data) } \\
\hline \multirow[t]{2}{*}{ Aggregate Data } & & & $-0.273^{*}$ & $-0.428 * * *$ & 0.826 \\
\hline & & & $(0.154)$ & $(0.113)$ & $(0.628)$ \\
\hline \multirow[t]{2}{*}{ Aggregate Data on Affiliates } & 1.084 & $1.276^{*}$ & $1.276^{* * *}$ & $1.276^{* * *}$ & $0.813^{*}$ \\
\hline & $(0.668)$ & $(0.731)$ & $(0.473)$ & $(0.465)$ & $(0.459)$ \\
\hline \multicolumn{6}{|l|}{$\begin{array}{l}\text { Tax Burden Measure } \\
\text { (Country Statutory Rate) }\end{array}$} \\
\hline \multirow{2}{*}{ Micro Average Tax Rate } & 0.537 & 0.657 & 0.657 & 0.657 & -0.814 \\
\hline & $(0.642)$ & $(0.591)$ & $(0.443)$ & $(0.461)$ & $(0.519)$ \\
\hline \multirow[t]{2}{*}{ Macro Average Tax Rate } & $-4.002 * * *$ & $-4.025 * * *$ & $-4.025 * * *$ & $-1.799 * * *$ & $-1.369^{*}$ \\
\hline & $(0.607)$ & $(0.714)$ & $(0.915)$ & $(0.614)$ & $(0.691)$ \\
\hline \multirow[t]{2}{*}{ State Statutory Tax Rate } & - & - & $-1.428 * * *$ & -0.460 & 1.373 \\
\hline & & & $(0.227)$ & $(0.326)$ & $(1.278)$ \\
\hline \multirow[t]{2}{*}{ Marginal Effective Tax Rate } & $-0.779 * * *$ & $-0.646 * *$ & $-0.646^{* *}$ & $-0.646^{* *}$ & $-0.989 * *$ \\
\hline & $(0.279)$ & $(0.298)$ & $(0.271)$ & $(0.265)$ & $(0.470)$ \\
\hline \multirow[t]{2}{*}{ Average Effective Tax Rate } & $-0.698^{*}$ & -0.548 & -0.548 & -0.548 & -0.0743 \\
\hline & $(0.364)$ & $(0.356)$ & $(0.442)$ & $(0.414)$ & $(0.290)$ \\
\hline \multirow[t]{2}{*}{ Bilateral Marginal Effective Tax Rate } & $2.207 * * *$ & $2.248^{* * *}$ & $2.248^{* * *}$ & $2.248^{* * *}$ & $0.718^{*}$ \\
\hline & $(0.369)$ & $(0.348)$ & $(0.342)$ & $(0.294)$ & $(0.373)$ \\
\hline \multirow[t]{2}{*}{ Bilateral Average Effective Tax Rate } & $3.692 * * *$ & $3.570 * * *$ & $3.570 * * *$ & $3.570 * * *$ & 0.919 \\
\hline & $(0.542)$ & $(0.521)$ & $(0.476)$ & $(0.431)$ & $(0.555)$ \\
\hline \multirow[t]{2}{*}{$\begin{array}{l}\text { No Control for Public Spending (Con- } \\
\text { trol) }\end{array}$} & 0.506 & 0.0810 & 0.0810 & 0.0810 & -0.148 \\
\hline & $(0.519)$ & $(0.316)$ & $(0.247)$ & $(0.452)$ & $(0.322)$ \\
\hline \multicolumn{6}{|l|}{ Specification (no Fixed Effects) } \\
\hline \multirow[t]{2}{*}{ Time Fixed Effects } & $-1.882 * * *$ & $-2.211 * *$ & $-2.211^{*}$ & $-2.211 * *$ & -1.066 \\
\hline & $(0.575)$ & $(0.877)$ & $(1.166)$ & $(0.893)$ & $(0.652)$ \\
\hline \multirow[t]{2}{*}{ Country Fixed Effects } & 0.0148 & 0.147 & 0.147 & 0.147 & $-0.755^{* * *}$ \\
\hline & $(0.891)$ & $(0.921)$ & $(0.497)$ & $(0.491)$ & $(0.248)$ \\
\hline OLS Estimation (other than OLS) & & $-0.749 * *$ & $-0.749 * * *$ & $-0.749 * * *$ & -0.216 \\
\hline & & $(0.298)$ & $(0.162)$ & $(0.156)$ & $(0.330)$ \\
\hline Type of Industry (not specified) & & & & & \\
\hline Manufacturing Industry & & -0.483 & -0.483 & -0.483 & 0.576 \\
\hline & & $(0.397)$ & $(0.393)$ & $(0.334)$ & $(0.387)$ \\
\hline Financial Services & & $1.148^{* *}$ & $1.148^{* *}$ & $1.148 * * *$ & 0.355 \\
\hline & & $(0.514)$ & $(0.463)$ & $(0.341)$ & $(1.005)$ \\
\hline Finance (not specified) & & & & & \\
\hline Retained earnings & & 0.176 & 0.176 & 0.176 & 0.0372 \\
\hline & & $(0.580)$ & $(0.719)$ & $(0.744)$ & $(0.680)$ \\
\hline Transfers of Funds & & -0.218 & -0.218 & -0.218 & -0.926 \\
\hline & & $(0.481)$ & $(0.621)$ & $(0.641)$ & $(0.622)$ \\
\hline
\end{tabular}




\begin{tabular}{|c|c|c|c|c|c|}
\hline \multirow[b]{2}{*}{ Dependent Variable: T-values } & \multicolumn{2}{|c|}{$\begin{array}{c}\text { Extensions } \\
\end{array}$} & \multicolumn{3}{|c|}{ Robustness Checks } \\
\hline & $\begin{array}{c}\text { FE-Extension } \\
1\end{array}$ & $\begin{array}{l}\text { FE-Extension } \\
\quad 2\end{array}$ & $\begin{array}{l}\text { Robustness } \\
\text { Check } 1\end{array}$ & $\begin{array}{l}\text { Robustness } \\
\text { Check } 2\end{array}$ & $\begin{array}{l}\text { Robustness } \\
\text { Check } 3\end{array}$ \\
\hline & $(1)$ & $(2)$ & (3) & $(4)$ & $(5)$ \\
\hline \multicolumn{6}{|l|}{$\begin{array}{l}\text { Double Taxation Relief System (not } \\
\text { specified) }\end{array}$} \\
\hline \multirow[t]{2}{*}{ Credit System } & & -0.125 & -0.125 & -0.125 & -0.116 \\
\hline & & $(0.460)$ & $(0.381)$ & $(0.336)$ & $(0.467)$ \\
\hline \multirow[t]{2}{*}{ Exemption System } & & -0.605 & $-0.605^{*}$ & $-0.605^{*}$ & $-1.168 * *$ \\
\hline & & $(0.456)$ & $(0.357)$ & $(0.309)$ & $(0.460)$ \\
\hline \multicolumn{6}{|l|}{ Control Variables (not included) } \\
\hline \multirow[t]{2}{*}{ Control for Home Tax } & & -0.759 & -0.759 & -0.759 & $-1.334 * *$ \\
\hline & & $(0.523)$ & $(0.741)$ & $(0.733)$ & $(0.564)$ \\
\hline \multirow[t]{2}{*}{ GDP } & & 0.972 & 0.972 & $0.647 * * *$ & -0.516 \\
\hline & & $(1.208)$ & $(0.772)$ & $(0.249)$ & $(0.558)$ \\
\hline \multirow[t]{2}{*}{ Openness } & & $-2.038 * * *$ & $-2.038 * * *$ & $-1.335 * * *$ & $-1.235^{* * *}$ \\
\hline & & $(0.407)$ & $(0.531)$ & $(0.241)$ & $(0.416)$ \\
\hline \multirow[t]{2}{*}{ Agglomeration Effects } & & -1.755 & -1.755 & $0.676^{*}$ & $-0.621^{*}$ \\
\hline & & $(2.378)$ & $(2.471)$ & $(0.362)$ & $(0.327)$ \\
\hline \multirow[t]{2}{*}{ Exchange Rate } & & -0.223 & -0.223 & -0.223 & $1.667^{*}$ \\
\hline & & $(1.319)$ & $(1.088)$ & $(1.256)$ & $(0.990)$ \\
\hline \multirow[t]{2}{*}{ Wage } & & 1.806 & $1.806^{*}$ & $0.826^{* * *}$ & 0.181 \\
\hline & & $(1.329)$ & $(0.976)$ & $(0.312)$ & $(0.416)$ \\
\hline \multicolumn{6}{|l|}{$\begin{array}{l}\text { FDI Target Regions (no specific } \\
\text { region) }\end{array}$} \\
\hline \multirow[t]{2}{*}{ Europe } & & & 0.159 & 0.155 & -0.520 \\
\hline & & & $(0.0988)$ & $(0.121)$ & $(0.419)$ \\
\hline \multirow[t]{2}{*}{ United States } & & & 0.162 & $-2.166^{* * *}$ & $-3.459 * * *$ \\
\hline & & & $(0.138)$ & $(0.326)$ & $(1.140)$ \\
\hline \multirow[t]{2}{*}{ Average Sample Year } & & -0.0127 & -0.0127 & -0.0127 & 0.0722 \\
\hline & & $(0.0568)$ & $(0.0692)$ & $(0.0725)$ & $(0.0492)$ \\
\hline \multicolumn{6}{|l|}{ Publication Bias } \\
\hline \multirow[t]{2}{*}{ Unpublished (Published) } & & - & $-1.186 * * *$ & $-0.713 * * *$ & $-0.936^{*}$ \\
\hline & & & $(0.219)$ & $(0.155)$ & $(0.477)$ \\
\hline \multirow[t]{2}{*}{ Constant } & $2.714 * * *$ & 28.90 & $29.56^{* * *}$ & $32.19 * * *$ & -135.9 \\
\hline & $(0.923)$ & $(112.9)$ & $(0.257)$ & $(0.474)$ & (96.74) \\
\hline Observations & 721 & 721 & 721 & 721 & 721 \\
\hline $\mathrm{R}^{2}$ & 0.086 & 0.130 & 0.456 & 0.456 & 0.313 \\
\hline F-test $(\mathrm{H} 0:$ all coefficients $=0)$ & $p=0.000$ & $\mathrm{p}=0.000$ & $\mathrm{p}=0.000$ & $\mathrm{p}=0.000$ & $\mathrm{p}=0.000$ \\
\hline \multicolumn{6}{|c|}{$\begin{array}{l}\text { Robust standard errors in parentheses. } * * * / * * / * \text { denotes significance at the } 1 \% / 5 \% / 10 \% \text { level. Primary t-values have been mul- } \\
\text { tiplied by }(-1) \text {. All extensions are estimated by fixed effects (within) estimation. Robustness checks } 1 \text { and } 2 \text { employ the fixed } \\
\text { effects vector decomposition technique (FEVD), see Pluemper and Troeger (2007). Robustness check } 1 \text { includes only within } \\
\text { study invariant characteristics into the } 2^{\text {nd }} \text { stage of the FEVD estimator, robustness check } 2 \text { uses FEVD with also the least within- } \\
\text { variant variables included into the } 2^{\text {nd }} \text { stage. Robustness check } 3 \text { is estimated by pooled FGLS. All study/model characteristics } \\
\text { (except average sample year) are coded as dummy variables. Thus, a base model represents the characteristics redundant to the } \\
\text { variables explicitly included. The base characteristics are indicated in parenthesis for each study dimension. Estimated coeffi- } \\
\text { cients of the dummies indicate the effect on primary t-values of choosing a characteristic in lieu of the base specification. }\end{array}$} \\
\hline
\end{tabular}

With respect to the influence of the data structure on primary results, the results in Column (4) suggest that both panel and cross-section significantly reduce primary t-values as compared to time-series studies. However, the majority of results do not back this conclusion. We therefore conclude that there are other study characteristics than the data structure which are decisive for estimated effect sizes.

Drawing on the specific issues analyzed in the extensions, we first can confirm that bilateral tax rates indeed do not only raise primary tax coefficients but also the measured significance of tax influences on FDI. In contrast, public spending still does not influence primarily identified t-values. It thus neither affects semi-elasticities nor their significance. From a theoretical 
point of view this is somewhat disappointing. However, one might conclude that the search for appropriate proxies of relevant public inputs should not yet be abandoned. Interestingly, country fixed effects do generally not have a significant influence on primary t-values. Obviously, tax burden measures in most studies show sufficient variation and are not absorbed into more general time-invariant location characteristics. It thus seems indeed advisable to control for location fixed effects especially in studies based on aggregate data, since this corrects some of the bias in measured tax coefficients (see again Table 12) without sacrificing significance of the tax effect. Time fixed effects significantly reduce the significance of primary tax effects. Tax effects are thus rather absorbed by temporary macroeconomic conditions within countries or regions than by static location characteristics. All these effects are robust to the extension towards the full model. Moreover, we find that the coefficients for the way of finance and openness of the target economy are fully in line with the prior results for semi-elasticities, i.e. their effects on primary tax coefficients and significance are congruent. Some of the remaining regressors (e.g. manufacturing industry data) seem to exert significant effects on semi-elasticities, but not on t-values or the other way around.

As concerns the assessment of publication bias we have to rely on FEVD estimates performed as a general robustness check in Column (3) of Table 13. Obviously, unpublished studies produce significantly lower t-values than published work. So this might not be in line with the conclusions we drew from Column (2) of Table 12. But note that current publication status might only reflect a temporary stage of the publication process and most researchers would probably not want to adjust results before or during the following review process. So the influence of publication status might rather reflect other effects adherent to relatively new work which was not adequately captured by the study-specific effects of our meta-regression than different (implicit) requirements as concerns significance for published and unpublished research. Therefore more weight should be given to the findings in Column (2) of Table 12 as this is clearly the more established way to cope with the issue. As a result, publication bias is not yet considered as unambiguously verified.

Strikingly, the influence of geographic FDI target regions ("Europe only" and "US only") on effect size estimates which we identified on the basis of the regressions based on semi-elasticities is confirmed only for the United States. Investors targeting this economy apparently do not base their decisions on tax aspects.

Finally, the results from FGLS estimation in Column (5) of Table 13 should be addressed. Most results are in line with those obtained from the fixed effects cluster econometric estima- 
tion. There are, however, also some differences. While the coefficient for country fixed effects is positive and significant, FGLS identifies no significant effect for time fixed effects. Also the results for macroeconomic average tax rates are of opposite sign and significant. Furthermore, no significant impact on primary t-values is identified for the bilateral average tax rate $(p=0.106)$. But remember that the evidence against simple pooled estimation from our series of tests is fairly pronounced. Thus, the pooled FGLS results are put into perspective. In addition, choosing the optimal meta-regression estimator is not a minor issue with respect to results, but represents a precondition for valid and reliable inference based on meta-data.

\section{Conclusions}

Tax competition and tax harmonization still are among the central themes in public economics. Proof of this contention is the ever increasing amount of theoretical and empirical studies. Meanwhile, meta-analyses of these empirical studies exist. This paper does not simply present another meta-analysis. In addition to an extension of the data base and a deeper methodological discussion and approach, the main interest of our paper is the moderating influence of control variables, in particular public spending and agglomeration effects, on the estimated tax rate effects on FDI as they could be obtained from the existing empirical studies.

According to our meta-analysis, a pooled effect based on medians, which seems rather robust to different variations, could be obtained that amounts to a semi-elasticity for company taxes on FDI of 1.68 in absolute terms. The most precise estimate of semi-elasticities is 1.39 in absolute terms. Both effects are highly significantly different from zero in statistical terms. While they obviously are also economically significant, this range of semi-elasticities is not implausibly high. Taxes matter for location decisions and FDI.

The meta-regressions reported in this paper indicate that the heterogeneity in the semi-elasticities and the t-statistics from the different empirical studies can be fairly well explained by characteristics of the studies. We do not find overwhelming support for publication bias in the meta-regressions with semi-elasticities as dependent variable, but some publication bias in the meta-regressions with $\mathrm{t}$ - and $\mathrm{z}$-statistics as dependent variable. The use of aggregate data leads to higher semi-elasticities, but significantly reduces t-values and thus implies less precise estimates. Using aggregate data on affiliates significantly increases both. The inclusion of country fixed effects might correct for some of the potential bias in aggregate studies, and it does not even lead to lower significances. Apparently tax rates are sufficiently time-variant. Interestingly we find that including time fixed effects reduces the significance of tax effects. 
Regarding the choice of tax rates, unilateral effective average tax rates do not lead to significantly higher tax effect size estimates or significances as compared to the statutory rate. Marginal effective tax rates even yield lower effects. This is probably not due to lower tax sensitivity of marginal investment decisions, because we find evidence that discrete investment choices are less sensitive. The low effect for EMTR might thus stem from problems of identifying marginal choices in reality. Bilateral tax rates best capture tax incentives and yield both significantly higher effect size estimates as well as higher significances. Finance and home country double taxation relief do not influence investment decisions.

Regarding the control variables, it is most interesting that primary estimates are not significantly affected by the inclusion of public spending. According to most estimates in the literature, the spending side does not moderate the tax rate effects. The results reported by Bénassy-Quéré et al. (2007) do thus not find general support. This might be due to the fact that only crude measures of public inputs are used in many studies. Similarly agglomeration effects do not have any robust significant effect on estimated tax effects on FDI in the primary studies.

Certainly, more research is needed to find out whether the provision of public goods is empirically related to tax rate effects or whether this is really a pure tax competition game.

\section{References}

Altshuler, R., H. Grubert and T.S. Newlon (2001), Has U.S. Investment Abroad Become More Sensitive to Tax Rates?, in: J.R. Hines (ed.), International Taxation and Multinational Activity, University of Chicago Press, Chicago, $8-32$.

Baldwin, R.E. and P. Krugman (2004), Agglomeration, Integration and Tax Harmonization, European Economic Review 48, 1 - 23.

Bartik, T.J. (1985), Business Location Decisions in the United States: Estimation of the Effects of Unionization, Taxes, and Other Characteristics of States, Journal of Business \& Economic Statistics $3,14-22$.

Bartik, T.J. (1991), Who Benefits from State and Local Economic Development Policies?, W.E. Upjohn Institute for Employment Research, Kalamazoo.

Becker, J., C. Fuest and T. Hemmelgarn (2006), How Does FDI React to Corporate Taxation? A Comment on Studies Using Aggregate Data, Working Paper, University of Cologne.

Beckmann, R. (2007), Profitability of Western European Banking Systems: Panel Evidence on Structural and Cyclical Determinants, Deutsche Bundesbank Discussion Paper Series 2: Banking and Financial Studies, DP No. 17/2007.

Bellak, C. and M. Leibrecht (2007), Some Further Evidence on the Role of Effective Corporate Income Taxes as Determinants of Foreign Direct Investment in Central and East European Countries, in: National Tax Association (ed.), Proceedings of the National Tax Association Conference 2006, Boston, $311-343$.

Bellak, C., M. Leibrecht and J.P. Damijan (2007), Infrastructure Endowment and Corporate Income Taxes as Determinants of Foreign Direct Investment in Central and Eastern European Countries, LICOS Discussion Paper Series No. 193/2007. 
Bénassy-Quéré, A., L. Fontagné and A. Lahrèche-Révil (2005), How Does FDI React to Corporate Taxation? International Tax and Public Finance 12, 583 - 603.

Bénassy-Quéré, A., N. Gobalraja and A. Trannoy (2007), Tax and Public Input Competition, Economic Policy 19, 385 - 430.

Bera, A.K. and W. Sosa-Escudero (2008), Tests for Unbalanced Error-Components Models under Local Misspecification, Stata Journal 8, 67 - 78.

Bijmolt, T.H.A. and R.G.M. Pieters (2001), Meta-Analysis in Marketing When Studies Contain Multiple Measurements, Marketing Letters 12, 157 - 169.

Billington, N. (1999), The Location of Foreign Direct Investment: An Empirical Analysis, Applied Economics 31, $65-76$.

Bloningen, B.A. (2005), A Review on the Empirical Literature on FDI Determinants, NBER Working Paper No. 11299.

Bobonis, G.J and H.J. Shatz (2007), Agglomeration, Adjustment, and State Policies in the Location of Foreign Direct Investment in the United States, Review of Economics and Statistics 89, 30 - 43.

Bom, P.R.D. and J.E. Ligthart (2008), How Productive is Public Capital? A Meta-Analysis, CESifo Working Paper Series WP No. 2206 and CenTER Discussion Paper Series DP No. 2008-10, Revised Version March 2008.

Boskin, M.J. and G. Gale (1987), New Results on the Effects of Tax Policy on the International Location of Investment, in: M. Feldstein (ed.), The Effects of Taxation on Capital Accumulation, University of Chicago Press, Chicago, $201-219$.

Broekman, P. and W.N. van Vliet (2001), Winstbelasting en Kapitaalstromen in de EU, Openbare Uitgaven 33, $46-53$.

Brons, M.R.E. (2006), Meta-Analytical Studies in Transport Economics: Methodology and Applications, Dissertation, Vrije Universiteit Amsterdam.

Brons, M., P. Nijkamp, E. Pels and P. Rietveld (2008), A Meta-Analysis of the Price Elasticity of Gasoline Demand. A SUR Approach, Energy Economics 30, 2105 - 2122.

Brueckner, J.K. (1979), Property Values, Local Public Expenditure and Economic Efficiency, Journal of Public Economics 11, 223 - 245.

Brueckner, J.K. (1982), A Test for Allocative Efficiency in the Local Public Sector, Journal of Public Economics 19, 311 - 331.

Brülhart, M., M. Jametti and K. Schmidheiny (2007), Do Agglomeration Economies Reduce the Sensitivity of Firm Location to Tax Differentials?, mimeo, Université de Lausanne.

Buettner, T. (2002), The Impact of Taxes and Public Spending on the Location of FDI: Evidence from FDI-Flows within Europe, ZEW Discussion Paper No. 02-17.

Buettner, T. and M. Ruf (2007), Tax Incentives and the Location of FDI: Evidence from a Panel of German Multinationals, International Tax and Public Finance 14, 151 - 164.

Buettner, T. and G. Wamser (2008), The Impact of Nonprofit Taxes on Foreign Direct Investment: Evidence from German Multinationals, forthcoming in: International Tax and Public Finance.

Cassou, S.P. (1997), The Link Between Tax Rates and Foreign Direct Investment, Applied Economics $29,1295-1301$.

Demekas, D.G., B. Horváth, E. Ribakova and Y. Wu (2007), Foreign Direct Investment in European Transition Economies - the Role of Policies, Journal of Comparative Economics 35, 369 - 386.

De Mooij, R.A. and S. Ederveen (2003), Taxation and Foreign Direct Investment: A Synthesis of Empirical Research, International Tax and Public Finance 10, 673 - 693.

De Mooij, R.A. and S. Ederveen (2005), Explaining the Variation in Empirical Estimates of Tax Elas- 
ticities of Foreign Direct Investment, Tinbergen Institute Discussion Paper, No. 2005-108/3.

De Mooij, R.A. and S. Ederveen (2006), What a Difference Does it Make? Understanding the Empirical Literature on Taxation and International Capital Flows, European Commission Economic Paper No. 261.

Desai, M.A., C.F. Foley and J.R. Hines (2004), Foreign Direct Investment in a World of Multiple Taxes, Journal of Public Economics 88, 2727 - 2744.

Devereux, M.P. (2006), The Impact of Taxation on the Location of Capital, Firms and Profit: A Survey of Empirical Evidence, Working Paper from Oxford University Centre for Business Taxation No. 702.

Devereux, M.P. and H. Freeman (1995), The Impact of Tax on Foreign Direct Investment: Empirical Evidence and the Implications for Tax Integration Schemes, International Tax and Public Finance 2, $85-106$.

Devereux, M.P. and R. Griffith (1998), Taxes and the Location of Production: Evidence from a Panel of US Multinationals, Journal of Public Economics 68, 335 - 367.

Devereux, M.P. and R. Griffith (1999), The Taxation of Discrete Investment Choices, IFS Working Paper No. W98/16.

Devereux, M.P. and B. Lockwood (2006), Taxes and the Size of the Foreign-Owned Capital Stock: Which Tax Rate Matters?, Paper presented at the European Tax Policy Forum 2006, London.

Dunning, J.H. (1981), International Production and the Multinational Enterprise, Allen \& Unwin, London.

Egger, P., S. Loretz, M. Pfaffermayr and H. Winner (2008), Bilateral Effective Tax Rates and Foreign Direct Investment, Working Paper from Oxford University Centre for Business Taxation No. 0802.

Erkel-Rousse, H. and D. Mirza (2002), Import Price Elasticities: Reconsidering the Evidence, Canadian Journal of Economics 35, $282-306$.

Feld, L.P. (2000), Steuerwettbewerb und seine Auswirkungen auf Allokation und Distribution: Ein Überblick und eine empirische Analyse für die Schweiz, Mohr Siebeck, Tübingen.

Feld, L.P., T. Baskaran and J. Schnellenbach (2007), Fiscal Federalism, Decentralization and Economic Growth: A Meta-Analysis, Unpublished Manuscript, University of Heidelberg.

Fuest, C., B. Huber and J. Mintz (2005), Capital Mobility and Tax Competition, Foundations and Trends in Microeconomics 1 (1), $1-62$.

Gatti, D. (2008), Macroeconomic effects of ownership structure in OECD countries, Paris School of Economics Working Paper No. 2008 - 09.

Goldstein, H. (1995), Multilevel Statistical Models, 2nd ed., Edward Arnold, London.

Gorter, J. and A. Parikh (2003), How Sensitive is FDI to Differences in Corporate Income Taxation within the EU?, De Economist 151, 193 - 204.

Grubert, H. and J. Mutti (1991), Taxes, Tariffs and Transfer Pricing in Multinational Corporate Decision Making, Review of Economics and Statistics 73, 285 - 293.

Grubert, H. and J. Mutti (2000), Do Taxes Influence Where U.S. Corporations Invest?, National Tax Journal 53, $825-837$.

Grubert, H. and J. Mutti (2004), Empirical Asymmetries in Foreign Direct Investment and Taxation, Journal of International Economics 62, 337 - 358.

Hajkova, D., G. Nicoletti, L. Vartia and K.-Y. Yoo (2006), Taxation, Business Environment and FDI Location in OECD Countries, OECD Economics Department Working Paper No. 502.

Hartman, D.G. (1984), Tax Policy and Foreign Direct Investment in the United States, National Tax 
Journal 37, $475-488$.

Hedges, L.V. and I. Olkin (1985), Statistical Methods for Meta-Analysis, Academic Press, Orlando.

Helpman, E. (1984), A Simple Theory of International Trade with Multinational Corporations, Journal of Political Economy 92, $451-471$.

Helpman, E. (1985), Multinational Corporations and Trade Structure, Review of Economic Studies 52, $443-458$.

Hines, J.R. (1996), Altered States: Taxes and the Location of Foreign Direct Investment in America, American Economic Review 86, 1076 - 1094.

Hines, J.R. (1997), Tax Policy and the Activities of Multinational Corporations, in: A.J. Auerbach (ed.), Fiscal Policy: Lessons from Economic Research, MIT Press, Cambridge, 401 - 445.

Hines, J.R. (1999), Lessons from Behavioral Responses to International Taxation, National Tax Journal 52, $305-322$.

Hines, J.R. and E.M. Rice (1994), Fiscal Paradise: Foreign Tax Havens and American Business, Quarterly Journal of Economics 109, 149 -182.

Horstmann, I.J. and J.R. Markusen (1992), Endogenous Market Structures in International Trade (natura facit saltum), Journal of International Economics 32, 109 - 129.

Hox, J. (2002), Multilevel Analysis. Techniques and Applications, Lawrence Erlbaum Associates, Mahwah.

Hunter, J.E. and F.L. Schmidt (1990), Methods of Meta-Analysis: Correcting Error and Bias in Research Findings, Sage Publications, Newbury Park.

Jacobs, O.H. and C. Spengel (1996), European Tax Analyzer, ZEW Wirtschaftsanalysen Bd. 11, Nomos, Baden-Baden.

Jarrell, S.B. and T.D. Stanley (1989), Meta-Regression Analysis: A Quantitative Method of Literature Surveys, Journal of Economic Surveys 3, $54-67$.

Jarrell, S.B. and T.D. Stanley (1990), A Meta-Analysis of the Union-Nonunion Wage Gap, Industrial and Labor Relations Review 44, 54 - 67.

Jarrell, S.B. and T.D. Stanley (2004), Declining Bias and Gender Wage Discrimination? A Meta-Regression Analysis, The Journal of Human Resources 39, 828 - 838.

Jarrell, S.B. and T.D. Stanley (2005), Meta-Regression Analysis: A Quantitative Method of Literature Surveys, Journal of Economic Surveys 19, 299 - 308.

Jun, J. (1994), How Taxation Affects Foreign Direct Investment: Country Specific Evidence, World Bank Policy Research Working Paper No.1307.

Keen, M. and M. Marchand (1997), Fiscal Competition and the Pattern of Public Spending, Journal of Public Economics 66, 33 - 53.

King, M.A. and D. Fullerton (1984), The Taxation of Income from Capital, University of Chicago Press, Chicago.

Longhi, S., P. Nijkamp and J. Poot (2008), Meta-Analysis of Empirical Evidence on the Labour Market Impacts of Immigration, IZA Discussion Paper Series No. 3418.

Neumark, F. (1963), Tax Harmonization in the Common Market ('Neumark-Report'), New York.

Nichols, A. and M.E. Schaffer (2007), Clustered Standard Errors in Stata, Papers by Stata User Group from United Kingdom Stata Users' Group Meetings 2007, No. 07.

Markusen, J.R. (1997), Trade Versus Investment Liberalization, NBER Working Paper No. 6231.

Markusen, J.R. (2002), Multinational Firms and the Theory of International Trade, MIT Press, Cambridge. 
Markusen, J.R., A. J. Venables, D. Eby-Konan and K. Honglin Zhang (1996), A Unified Treatment of Horizontal Direct Investment, Vertical Direct Investment and the Pattern of Trade in Goods and Services, NBER Working Paper No 5696.

Martens-Weiner, J. (2006), Company Tax Reform in the European Union: Guidance from the United States and Canada on Implementing Formulary Apportionment in the EU, Springer, New York.

McFadden, D. (1974), Conditional Logit Analysis of Qualitative Choice Behavior in: P. Zarembka (ed.), Frontiers in Econometrics, Academic Press, New York, 105 - 142.

McFadden, D. (1978), Modeling the Choice of Residential Location, in: A. Karlquist et al. (eds.), Spatial Interaction Theory and Planning Models, North-Holland, Amsterdam, 75 - 96.

Murthy, N.R.V. (1989), The Effects of Taxes and Rates of Return on Foreign Direct Investment in the United States: Some Econometric Comments, National Tax Journal 42, 205 - 207.

Newlon, T.S. (1987), Tax Policy and Multinational Firm's Financial Policy and Investment Decisions, Ph. D. Thesis, Princeton University.

Overesch, M. and G. Wamser (2008a), The Effects of Company Taxation in EU Accession Countries on German Multinationals, Paper prepared for the Meeting of the European Tax Policy Forum, London.

Overesch, M. and G. Wamser (2008b), Who Cares about Corporate Taxation? Asymmetric Tax Effects on Outbound FDI, ifo Working Paper No. 59.

Pain, N. and G. Young (1996), Tax Competition and the Pattern of European Foreign Direct Investment, mimeo, National Institute of Economic and Social Research.

Papke, L.E. (1991), Interstate Business Tax Differentials and New Firm Locations: Evidence from Panel Data, Journal of Public Economics 45, 47 - 68.

Pluemper, T. and V.E. Troeger, Efficient Estimation of Time-Invariant and Rarely Changing Variables in Finite Sample Panel Analyses with Unit Fixed Effects, Policy Analysis 15, 124 - 139.

Razin, A., Y. Rubinstein and E. Sadka (2005), Corporate Taxation and Bilateral FDI with Threshold Barriers, NBER Working Paper No. 11196.

Schanz, G. von (1890), Die Steuern der Schweiz in ihrer Entwicklung seit Beginn des 19. Jahrhunderts, Vol I to V, Cotta'sche Buchhandlung, Stuttgart.

Schmenner, R.W. (1982), Making Business Location Decisions, Prentice-Hall Inc., Englewood Cliffs.

Schön, W., U. Schreiber and C. Spengel (eds.) (2008), A Common Consolidated Corporate Tax Base for Europe, Springer, Berlin and Heidelberg.

Shang-Jin, W. (1997), How Taxing is Corruption on International Investors? NBER Working Paper No. 6030.

Sinn, H.-W. (2003), The New Systems Competition, Blackwell, Oxford.

Slemrod, J. (1990), Tax Effects on Foreign Direct Investment in the U.S.: Evidence from a CrossCountry Comparison, in: A. Razin and J. Slemrod (eds.), Taxation in the Global Economy, University of Chicago Press, Chicago, 79 - 122.

Spengel, C. (1995), Europäische Steuerbelastungsvergleiche: Deutschland - Frankreich - Großbritannien, IDW-Verlag, Düsseldorf.

Spoerer, M. (2002), Wann begannen Fiskal- und Steuerwettbewerb? Eine Spurensuche in Preußen, anderen deutschen Staaten und der Schweiz, Jahrbuch für Wirtschaftsgeschichte 2, 11 - 35.

Stanley, T.D. (1998), New Wine in Old Bottles: A Meta-Analysis of Ricardian Equivalence, Southern Economic Journal 64, 713 - 727.

Stanley, T.D. (2000a), Challenging Time Series: Limits to Knowledge, Inertia and Caprice, Edward Elgar, Cheltenham. 
Stanley, T.D. (2000b), An Empirical Critique of the Lucas Critique, Journal of Socio-Economics 29, $91-107$.

Stanley, T.D. (2001), Wheat from Chaff: Meta-Analysis as Quantitative Literature Review, Journal of Economic Perspectives 15, 131 - 150.

Stanley, T.D. (2005), Beyond Publication Bias, Journal of Economic Surveys 19, 309 - 345.

Stanley, T.D. (2008), Meta-Regression Methods for Detecting and Estimating Empirical Effects in the Presence of Publication Selection, Oxford Bulletin of Economics and Statistics 70, 103 - 127.

Stanley, T.D. and S.B. Jarrell (1989), Meta-Regression Analysis: A Quantitative Method of Literature Surveys, Journal of Economic Surveys 3, $54-67$.

Stanley, T.D. and S.B. Jarrell (1998), Gender Wage Discrimination Bias? A Meta-Regression Analysis, Journal of Human Resources 33, 947 - 973.

Stöwhase, S. (2005a), Tax-Rate-Differentials and Sector-Specific Foreign Direct Investment: Empirical Evidence from the EU, FinanzArchiv 61, 535 - 558.

Stöwhase, S. (2005b), Taxes and Multinational Enterprises in the EU: Location Decisions and Income Shifting, Dissertation, LMU München.

Swenson, D.L. (1994), The Impact of U.S. Tax Reform on Foreign Direct Investment on Foreign Direct Investment in the United States, Journal of Public Economics 54, 243 - 266.

Swenson, D.L. (2001), Transaction Type and the Effect of Taxes on the Distribution of Foreign Direct Investment in the United States, in: J.R. Hines (ed.), International Taxation and Multinational Activity, University of Chicago Press, Chicago, $89-112$.

Thompson, S.G. and S.J. Sharp (1999), Explaining Heterogeneity in Meta-Analysis: A Comparison of Methods, Statistics in Medicine 18, 2693 - 2708.

Tiebout, C.M. (1956), A Pure Theory of Local Expenditures, Journal of Political Economy 64, 416 424.

Volckart, O. (2002), Wettbewerb und Wettbewerbsbeschränkung im vormodernen Deutschland 1000 1800, Mohr Siebeck, Tübingen.

Wijeweera, A., B. Dollery and D. Clark (2007), Corporate Tax Rates and Foreign Direct Investment in the United States, Applied Economics 39, 109 - 117.

Wilson, J.D. (1999), Theories of Tax Competition, National Tax Journal 52, 269 - 304.

Wilson, J.D. and D.E. Wildasin (2004), Capital Tax Competition: Bane or Boon?, Journal of Public Economics 88, 1065 - 1091.

Wolff, G.B. (2007), Foreign Direct Investment in the Enlarged EU: Do Taxes Matter and to What Extent?, Open Economies Review 18, 327 - 346.

Wooldridge, J.M. (2002), Econometric Analysis of Cross Section and Panel Data, MIT Press, Cambridge.

Wooldridge, J.M. (2003), Cluster-Sample Methods in Applied Econometrics, American Economic Review 93, 133 - 138.

Young, K.H. (1988), The Effects of Taxes and Rates of Return on Foreign Direct Investment in the United States, National Tax Journal 41, 109 - 121.

Zodrow, G.R. and P. Mieszkowski (1986), Pigou, Tiebout, Property Taxation and the Underprovision of Local Public Goods, Journal of Urban Economics 19, 356 - 370. 